T.C.

MARMARA ÜNIVERSITESI

SOSYAL BILIIMLER ENSTİTÜSÜ

RADYO SINEMA TELEVIZYON ANABİLIM DALI

İLETIȘIMM BİLIMMLERİ BİLIMM DALI

\title{
POPÜLER BİR KÜLTÜR ÖRNEĞİ OLARAK FUTBOL
}

YÜKSEK LİSANS TEZI

JETEMIR GASHI

İstanbul 2015 
T.C.

MARMARA ÜNIVERSITESI

SOSYAL BILIIMLER ENSTİTÜSÜ

RADYO SINEMA TELEVIZYON ANABİLIM DALI

İLETIȘIMM BİLİMLERİ BİLİM DALI

\section{POPÜLER BİR KÜLTÜR ÖRNEĞİ OLARAK FUTBOL \\ YÜKSEK LİSANS TEZİ}

Jetemir GASHI

Danışman

YRD. DOÇ. DR. AYŞE KONCAVAR 
T.C.

MARMARA ÜNIVERSITTESI

SOSYAL BILIMMLER ENSTITUÜSÜ MÜDÜRLLÜĞÜ

TEZ ONAY BELGESI

RADYO, TELEVIZZYON VE SINEMA Anabilim Dalı ILLETISSIM BİLIMMLERİ Bilim Dalı TEZLI YÜKSEK LİSANS öğrencisi JETEMIR GASHI'nın POPÜLER BİR KÜLTÜR ÖRNEĞI OLARAK FUTBOL adlı tez çalıșması, Enstitümüz Yönetim-Kurulunun 10.07.2015 tarih ve 2015-26/12 sayılı kararıyla oluşturulan jüri tarafindan oy birliği oy çokluğu ile Yüksek Lisans Tezi olarak kabul edilmiștir.

Tez Savunma Tarihi $23 . .87$.

\begin{tabular}{|c|c|c|c|}
\hline Öğ & etim Üyesi Adı S & yadı & İmzası \\
\hline 1. & Tez Danışmanı & Yrd. Doç. Dr. AYȘE KONCAVAR & \\
\hline 2. & Jüri Üyesi & Doç. Dr. NEŞE KAPLAN & \\
\hline 3. & Jüri Üyesi & Doç. Dr. NAZAN ALIOOĞLU & \\
\hline
\end{tabular}




\section{ÖNSÖZ}

Günümüzde futbol, popüler kültürün en önemli örneklerinden biri olarak gösterilmektedir. Tarihsel gelişim içerisindeki süreçlerden en çok etkilenen ve buna bağlı olarak kitleleri en çok etkileyen oyun şüphesiz ki futboldur. Futbol her şeyden evvel bir oyundur ve oyunun tarihi en az kültür kadar eskilere dayanmaktadır. Bu bağlamda kültür, popüler kültür, oyun ve son olarak futbol kavramları, birbirleriyle olan etkileşimi ve değişim süreçleri, geçmişten günümüze kadar olan dönemde aktarılmaya çalışılmıştır

Çalışmamda yapılması amaçlanan, futbolun bir oyun olarak ortaya çıkışından sonra nasıl popüler kültürün en önemli unsurlarından biri haline geldiği, kitleleri nasıl etkilediği, neden bu kadar sevilen bir oyun olduğu gibi soruları cevaplandırmak ve futbolun popülerleşme süreci ile birlikte endüstri haline gelmesine rağmen en önemli serbest zaman etkinliklerinden biri olduğu, bir sığınma bir arınma aracı olması gibi hususlarda bilgiler aktarmaktır.

$\mathrm{Bu}$ çalışmaya yapmamda beni iten ana unsur; futbolu seyreden, oynayan, hakkında araştırmalar yapan, izleyen ve çok seven biri olarak, milyonlarca insanı peşinden sürükleyen bu oyunun neden bu kadar ilgi çekici ve popüler olması ve hatta toplumların afyonu benzetmesi yapılması? Gibi soruların çözüme kavuşması ve futbol literatürüne akademik olarak yaklaşma kaygısıdır.

Üniversite ve yüksek lisans dönemim boyunca bana her zaman destek veren ve her türlü fedakarlıktan sakınmayan annem Sevdije Gashi, babam Bajram Gashi, ağabeyim Bujar Gashi'ye sonsuz sevgi ve teşekkürlerimi sunarım.

$\mathrm{Bu}$ çalışmayı hazırlamamda, bana sürekli destek ve yardımlarda bulunan yeğenim Emre Kaya' ya, gerek moral gerekse motivasyon açısından hep yanımda olan dostlarım İlter Urun ve Kutlay Urun'a, tez yazımı hakkında beni yönlendiren değerli arkadaşım Onur Sherifi' ye teşekkürlerimi borç bilirim. Çalışmayı yazma ve tamamlama süreci içinde fikirlerini ve yardımlarını esirgemeyen tez danışmanım Yrd.Doç.Dr. Ayşe Taş Koncavar'a ve Doç. Dr. Neşe Kaplan'a teşekkürlerimi sunarım.

Jetemir Gashi, İstanbul, 2015 


\section{İÇINDEKILER}

ÖNSÖZ

RESIMLER LISTESİ...........................................................................................................iv

TABLOLAR LISTESİ............................................................................................................ v

ÖZET

ABSTRACT ....................................................................................................................... vii

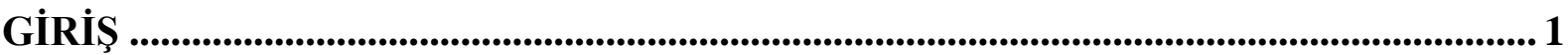

1. BÖLÜM: POPÜLER KÜLTÜR NEDİR? ............................................................................ 3

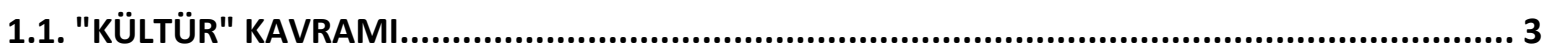

1.1.1. Kültür Nedir? ................................................................................................................. 3

1.1.2.1 Halk Kültürünün Sözlü ve Yazılı Kaynakları ................................................................ 5

1.1.3 Kitle Kültürü ve Kültür Endüstrisi .................................................................................... 5

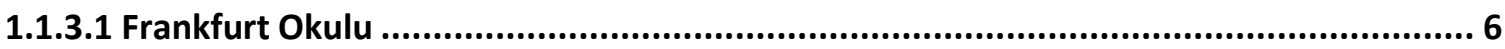

1.1.3.2. Kültür Endüstrisine Eleştirel Bakış Açısı........................................................................ 7

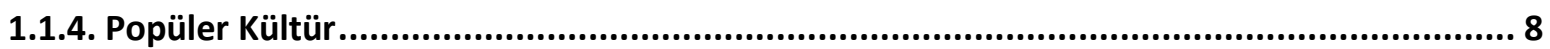

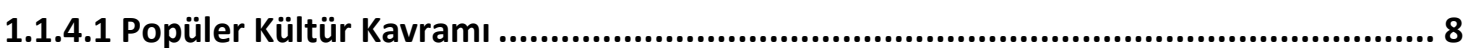

1.1.4.2. Popüler Kültüre Farklı Yaklaşımlar ...................................................................... 11

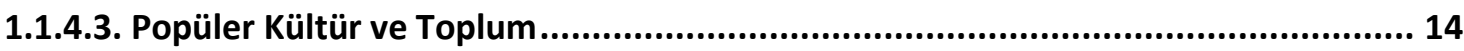

1.1.4.4. Popüler Kültürün Genel Özellikleri ........................................................................ 17

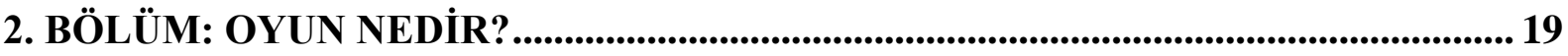

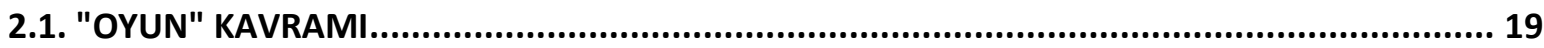

2.1.1. Oyunun Genel Özellikleri ............................................................................................... 19

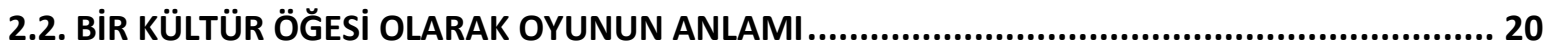

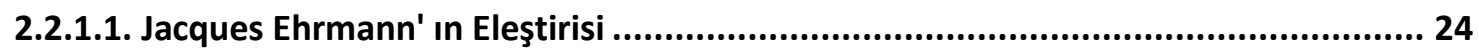

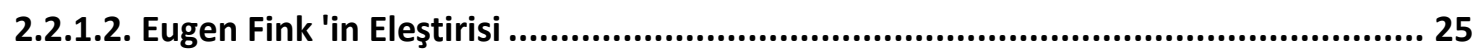

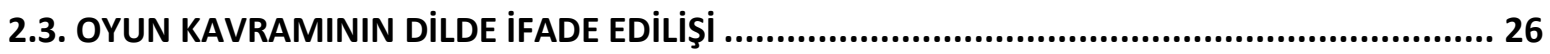

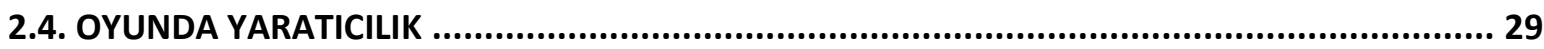

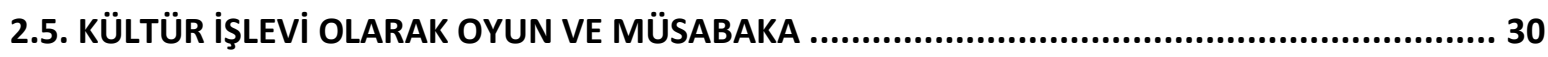

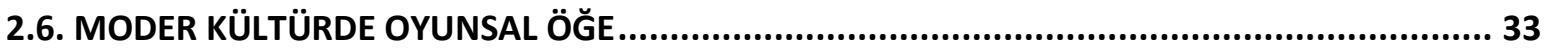

2.6.1. Bir Oyunsal Öğe Olarak Spor Kavramı ve Turnuva ......................................................... 33

3.BÖLÜM:POPÜLER BİR KÜLTÜR ÖRNEĞİ OLARAK FUTBOL OYUNU ..............36

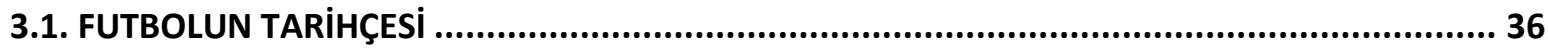




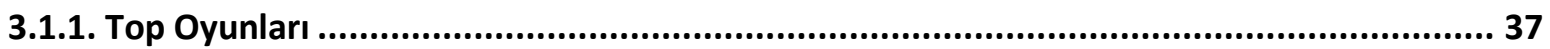

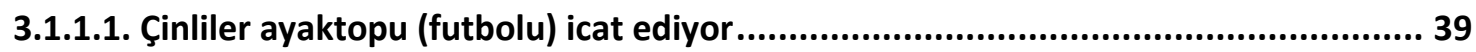

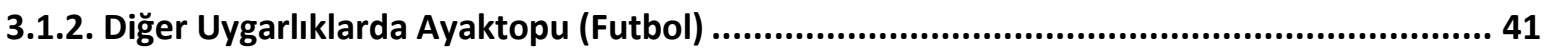

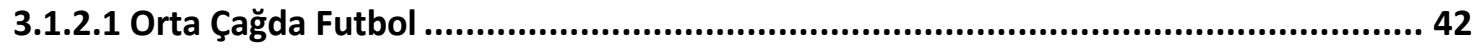

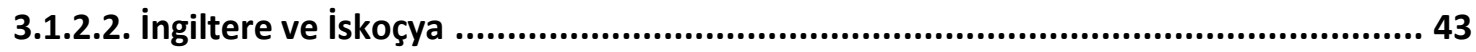

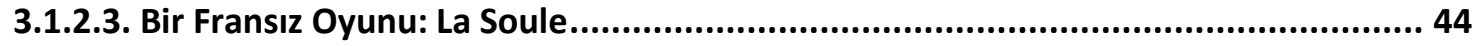

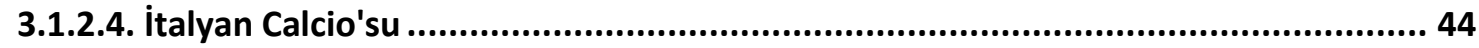

3.1.2.5. Ayaktopu: evrensel bir geleneksel oyun .......................................................... 45

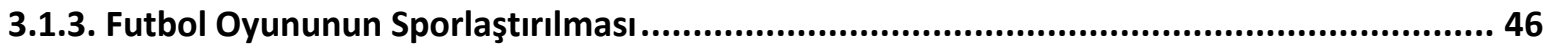

3.1.3.1 Football Association'ın Kuruluşu (Futbol Birliği) ................................................. 46

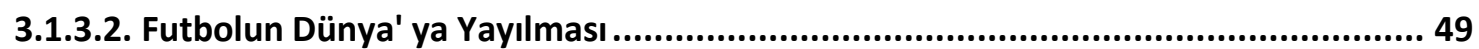

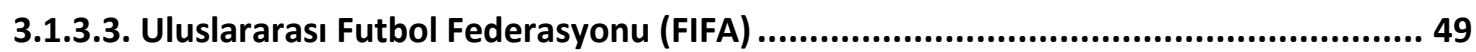

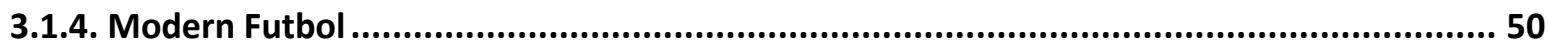

3.2. FUTBOL OYUN KURALLARI TARIHSEL GELişiMi .............................................................. 51

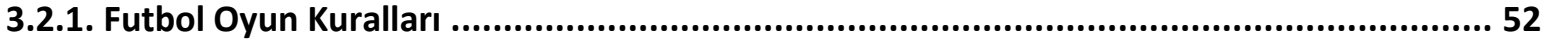

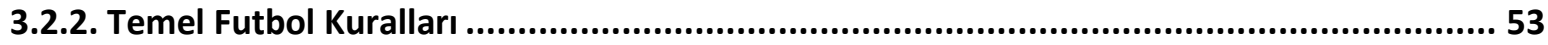

3.3. iş̧̧̧i FUTBOLUNUN MODERN FUTBOLUN GELişiMiNE ETKISi ......................................... 57

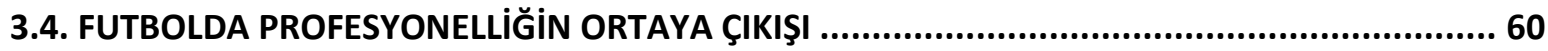

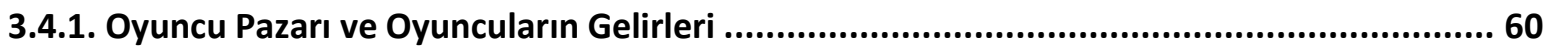

4.BÖLÜM: FUTBOLUN POPÜLERLEŞME SÜRECİ VE KÜLTÜREL ......................... 62

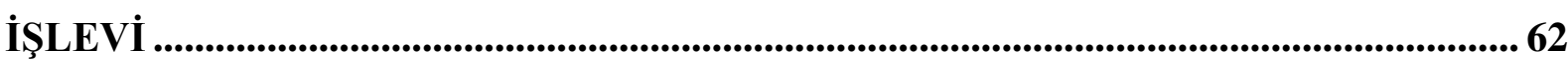

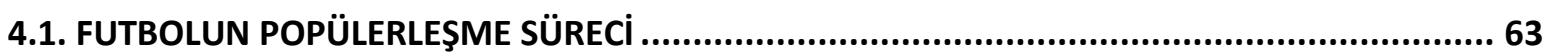

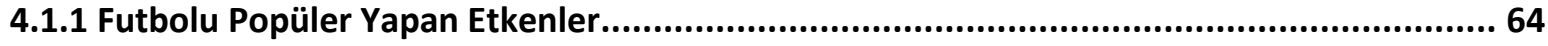

4.1.1.1. En Önemli Medya Unsuru Olarak Televizyon ve Futbol ........................................... 66

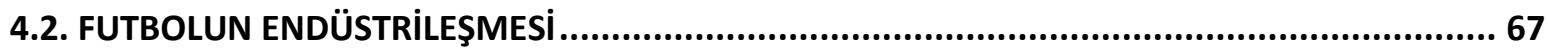

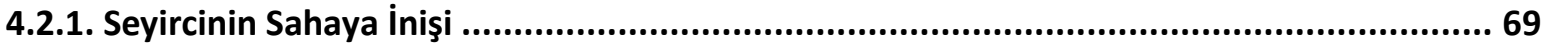

4.3. FUTBOL OYUNUNUN BIR ÖZGÜRLEŞME VE MÜCADELE ALANI OLARAK POTANSIYYLLIKLERI 71 SONUÇ.................................................................................................................................... 73

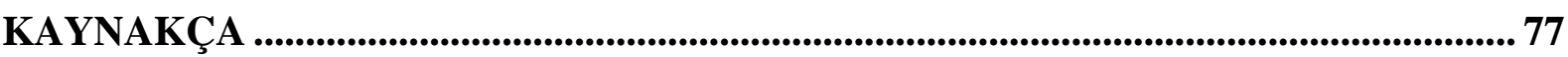




\section{RESIMLER LISTESİ}

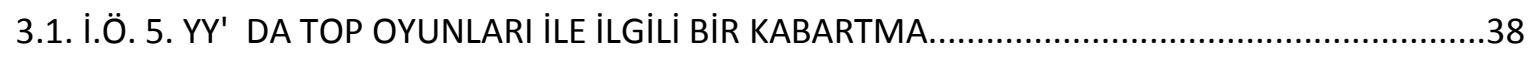

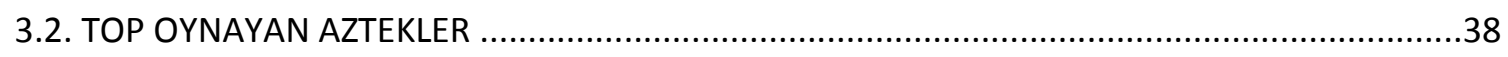

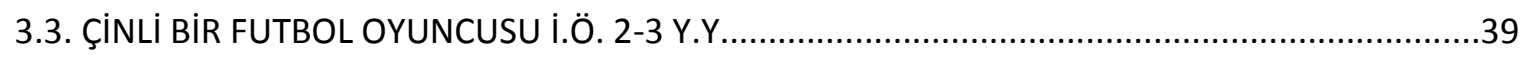

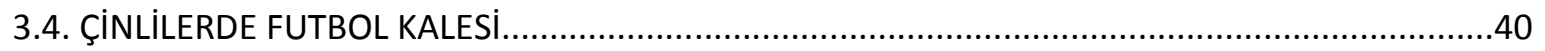

3.5. ORTAÇAĞ INGILTERESI' NDEN BIR FUTBOL KARESI.............................................................43

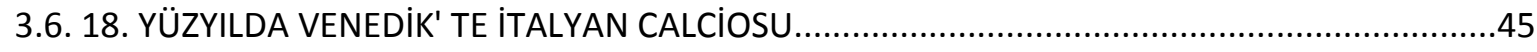

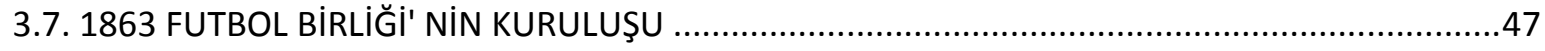

3.8. işÇi FUTBOLUNUN BIR SONUCU OLARAK KURULAN ARSENAL KULÜBÜ 1914-1915...................57 


\section{TABLOLAR LISTESI}

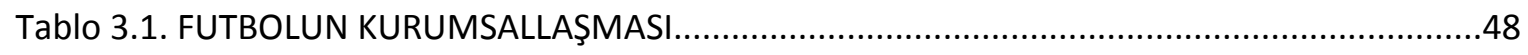

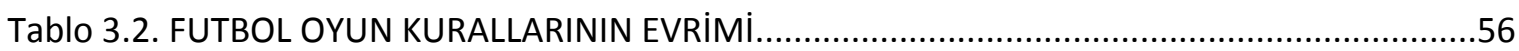




\section{ÖZET}

Kültür, toplulukların bireysel ve toplu yaşamlarını açıklamada, düzenlemede ve örgütlemede kullandıkları inançlar ve adetlerin bütünü olarak tanımlanır. Kültür kavramı, zaman içerisindeki değişimlere paralel olarak, önce kitle kültürüne daha sonra da popüler kültüre zemin hazırlamıştır. Popüler kültür en net ve geçerli tanımıyla, halk tarafından benimsenen ve en çok sevilen anlamına gelmektedir. Bu bağlamda, birçok popüler kültür öğesi karşımıza çıkmaktadır. Bunlar; müzik, spor, moda vb. alanları kapsamaktadır. Tabi ki popüler kültür kavramının ortaya çıkmasının en önemli sebeplerinden biri medyadır. Medya dediğimiz unsur, kitle iletişim araçları olan televizyon, radyo, internet vb. araçlardır. $\mathrm{Bu}$ araçlar en kısa sürede kitleleri yayılabilme özelliğine sahiptir. Bu bağlamda ortaya çıkan popüler kültür kavramı, gerek toplumla ilişkisi gerekse de kendi başına yarattığı etki gücüyle birçok farklı yaklaşımı ve çalışmayı da beraberinde getirmiştir.

Popüler kültürle birlikte dönüşüm ve değişim içerisine giren bir başka kavram da "oyun" kavramıdır. Oyun, tarihçilerin yaptığı araştırmalara göre; kültür kadar eski olduğu bilinen bir olgudur. En genel tanımıyla oyun; eğlenceyi, ciddiyetten uzaklaşmayı, keyifli vakit geçirmeyi aklımıza getiren sosyal hayatın önemli unsurlarından biri olarak tanımlanmaktadır. Oyuna bireyi iten, tanınma isteği, rahatlama ihtiyacı, yeni bir faaliyeti deneme arzusu ve sosyalleşme isteği gibi nedenlerdir. Oyun kavramı, gerek özellikleri gerek yaratıcılık gerektiren unsurları itibariyle zamanla spor ve müsabakaya dönüşmüş ve farklı şekillere bürünmüştür. Futbol da, bu oyunların en önemli ve en ilgi çekici olanıdır.

Futbol, her şeyden evvel bir oyun olarak ortaya çıkmıştır. Yapılan araştırmalara göre, günümüz modern futbolundan önce top oyunların söz etmek gerekmektedir. Bu oyunlar, eski Çin, Maya, Aztek gibi çok eski uygarlıklara kadar dayanmaktadır ancak günümüzdeki anlamıyla futbol, 19. yüzyılda İngiltere'de ortaya çıkmıştır. Sanayi Devrimi'nin de etkisiyle etki alanını genişletmiş, dünyaya yayılmış ve popülerleşmiştir. Yakın tarihimizle birlikte milyonları peşinden sürükleyen futbol, artık spor ve oyun kavramlarının önüne geçerek endüstri haline gelmiş ve dünyanın her yerinde tartışmasız yaygın bir hal almıştır.

Anahtar Kelimeler: Kültür, Popüler Kültür, Oyun, Futbol, Spor, Endüstri.. 


\begin{abstract}
Culture, in the description of the individual and collective life of the community, the faith they use in editing and organizing and is defined as a set of criteria. The concept of culture, in parallel with the change in time, before then prepared the ground for mass culture than turned to the populer culture. Popular culture with the most clear and valid definition : It means adopted and the most beloved by the public. In this context, we come across many popular culture items like; music, sport, fashion etc. Of course, one of the most important reason for populer culture is media. Elements that we call media is, the mass media, television radio, internet etc. These tools have the ability to spread as soon as to the masses. The concept of popular culture emerged in this context, the relationship with the community as well as it is needed to bring many different approaches and work with the effect that the power of its own.

Popular culture together within the concept of transformation and change within another " game " concept. Game, according to the research of historians ; it is a phenomenon known as old as culture. In its most general definition game means ; entertainment, a departure from the seriousness, defined as one of the important aspects of social life that brings to our mind to spend a pleasant time. It pushes the individual game demands recognition, to need to relax, as the causes desire to try new activities and socializing request. The concept of the game, as necessary features required elements that require creativity and had become a sports competition schedule and dressed in different ways. Football is the most important and most interesting of these games.

Football, before everything has emerged as a game. According to the research, it is necessary today to talk about the ball game before the modern football. These games, dates back to, the ancient civilizations such as the ancient Chinese, Mayan and Aztecs, but football is literally today, it emerged in the 19th century in England. Industrial Revolution also expanded its domain under the influence, spread throughout the world and popularized. After dragging our recent history with millions of football; which has now become the industry, surpassing the concepts of sport and play and become widespread all over the world.
\end{abstract}

Key Words: Culture, Popular Culture, Game, Football, Sport, Industry.. 


\section{GíRiş}

Kültür, insan topluluklarının bireysel ve toplu yaşamlarını ifade etmede, organize etmede ve örgütlemede kullandıkları inançlar ve adetlerin bütünü olarak tanımlanır. Kültür kavramı, değişen ve gelişen süreç çerçevesinde önce kitle kültürüne daha sonra da popüler kültüre zemin hazırlamıştır.

Popüler kültür en basit tanımıyla, halk tarafından benimsenen ve en çok sevilen anlamına gelmektedir. Bu bağlamda, tarihsel gelişim sürecinde birçok popüler kültür öğesi karşımıza çıkmaktadır. Bunlar; müzik, spor, moda vb. alanları kapsamaktadır. Tabi ki popüler kültür kavramının ortaya çıkmasının en önemli sebeplerinden biri medyadır. Medyadan kastımız, kitle iletişim araçları olan televizyon, radyo, internet vb. araçlardır. Bu araçlar çok kısa süreli dilimler içerisinde kitlelere hızlı bir şekilde yayılmaktadır ve bunun sonucu olarak popüler kültür kavramı ortaya çıkmıştır. Günümüzde de popüler kültürün en önemli öğelerinden biri de kuşkusuz futboldur.

Futbol profesyonel tanımıyla, 2 rakip takım ve 11 er oyuncudan oluşan kendine özel ve evrensel kuralları olan, bir topla ve ayak ile oynanan tüm dünyaca benimsenmiş bir oyundur. Modern anlamda futbol, 19. yüzyılda İngiltere'de sanayi devriminin bir sonucu olarak ortaya çıkmıştır. Ortaya çıktığı dönemden itibaren, kısa süre içerisinde benimsenmiş ve çok sevilmiştir ancak o dönemlerde bir takım karışıklıklara ve sorunlara yol açabilecek seviyeye kadar gelmesinden dolayı, kısa bir dönem İngiltere Krallığı tarafından yasaklanmıştır. Buna rağmen özellikle işçi sınıfı tarafından vazgeçilmez bir noktaya geldiği için bu yasak çok kısa süreli olmuştur. Sanayi devriminin bir sonucu olarak ortaya çıkan kapitalist sistemin götürüleri ve buna bağlı olarak işçi sınıfının fazla çalışma saatlerinin olması insanların sosyal hayatlarını kısıtlamıştır. Çalışma saatleri dışında insanlar kendilerine bir uğraş edinme gereği duymuşlardır. Bunun üzerine futbol en önemli sosyal aktivitelerden biri olmuştur. Geçmişten günümüze en çok sevilen, en çok izlenen ve en çok oynanan bir oyun halini almıştır.

Futbolun bu kadar oynanması, izlenmesi, sevilmesi, benimsenmesi ve yayılması onu popüler bir hale getirmiştir. Bu da futbolun popüler kültürün önemli örneklerinden biri 
olmasının en büyük sebeplerinden birisidir. Böylece futbol günümüze kadar milyonlarca insanı etkisi altına almıştır. Futbol'un popülerleşme süreci ile birlikte yeniden üretilmesi ve onu oyun yapan argümanlarını terk etmeye başlamasına rağmen hala en önemli serbest zaman etkinliği, bir kaçış ve sığınma alanı ve bireylerin kendini ifade edebilme ortamının sağlanması gibi hususlarda eleştirel bakış açısı ile anlatım yapma amacı gütmekteyim.

"Popüler Bir Kültür Örneği Olarak Futbol" adlı projemde öncelikle esinlendiğim kaynakların başlıcaları şunlardır; Futbol ve Kültür, Gölgede ve Güneşte Futbol, Cogito Futbol Sayısı 2010, Homo Ludens ve Popüler Kültürler Rock ve Sporda Haz Politikası...

Asıl esin kaynağım, 2010 yılında edinmiş olduğum, çok sevdiğim futbola akademik açıdan yaklaşan ve bu konu hakkında çalışma yapma isteği uyandıran Cogito Futbol 2010 sayısı (Dünya Gözüyle Futbol) adlı eserdir.

Ansiklopediler, kitaplar, makaleler, bilimsel dergiler (kısaca yazılı kaynaklar) kütüphane, arşiv merkezleri gibi yerlerde taranması ile çalışmanın alt yapısı oluşturulup, konunun bütünlüğü için gerekli araştırmalar yapılmış olup, özellikle Huizinga'nın oyun kavramı esas alınarak eleştirel kuramlar çerçevesinde, futbolun işlevi tartışılmıştır. 


\section{BÖLÜM: POPÜLER KÜLTÜR NEDİR?}

\section{1. "KÜLTÜR" KAVRAMI}

\subsubsection{Kültür Nedir?}

"Culture", kavramı Latince "cultura"dır, o da kök sözcük colere'den gelir. Colere bir dizi anlam taşır: ikamet etmek, yetiştirmek, korumak, ibadetle onurlandırmak gibi. $\mathrm{Bu}$ anlamların bir kısmı zamanla ayrışmıştır. Daha sonraki dönemde "cultura" yetiştirme veya bakma anlamlarını kazanmıştır, bir nevi ekinler ve hayvanların bakımı olarak değerlendirilebilir. ${ }^{1}$ 16. yüzyılın başlarından itibaren doğal büyümenin gözetilmesi insan gelişimi sürecini içine alacak bir biçimde genişlemiştir ve 19. yüzyılın başına doğru bir değişime uğramıştır. Bu değişimle birlikte "culture" kavramı modern anlamda kullanıldığı hale bürünmüştür. ${ }^{2}$

Kültür, nesilden nesile aktarılan bir miras durumundadır. $\mathrm{Bu}$ miras birike birike toplumsal bir hal almaktadır. Toplumsallaşma, kültürün gerçek anlamda aktifleşmesiyle mümkündür. Kültür olmadan toplumsallaşma olgusunun ortaya çıkması oldukça zordur. Toplumun mihenk taşı olan kültür kitleleri de bir arada tutmaktadır. Tarihin bu noktadaki rolü de yadsınamaz derecede büyüktür. ${ }^{3}$

Kültür, belirli bir toplumda yaşayan insanların dilini, dinini, yiyip içmesini, sosyal yaşantısını, bilgi ve görgü kurallarını, manevi değerlerini içine alır. Kültür toplumun temel taşıdır. Toplum kültürsüz olamayacağı için en ilkelinden en modernine kadar her toplumun kendine özgü bir kültürü vardır. ${ }^{4}$

Kültür, insan oluşumundan bugüne kadarki süre içinde toplumsal ilerleme ile bireyin gelişmesi arasındaki karşılıklı ilintiyi oluşturur. Toplum ile kültür arasındaki tarihsel diyalektik, toplumsal oluşumlar sonucu, bireyin içinde bulunduğu; emek, iş bölümü, birlikte çalışma, iletişim vb. temel ilişkilerde olduğu kadar, bunların bireyde bir özellik oluşturuyor

\footnotetext{
${ }^{1}$ Raymond Williams, Anahtar Sözcükler(Kültür ve Toplumun Sözvarlığı), Iletiş̧im Yayınları, 2012, S:105

2 Williams, A.g.e, S:106

${ }^{3}$ Temel Britannica, Hürriyet Gazetesi Yayınları, Cilt 11, İstanbul, 1993, S:172

${ }^{4}$ https://www.academia.edu/9881624/DEDE_N\%C4\%BONE_TORUN_KU\%C5\%9EAKLAR_ARASI_\%C3\%87ATI\%C5\%9EMALAR DA_POP\%C3\%9CLER_K\%C3\%9CLT\%C3\%9CR_, (20.03.2015)
} 
olması, ilerleyen uygarlıkla birlikte bireyin gittikçe toplumsallaşmasıyla ifade edilir. Tam bu noktada kültür, toplumsal ilerleme ile bireyin gelişimi arasında bağlantı kuran bir araçtır. ${ }^{5}$

UNESCO'ya göre de kültür: "Bir insan topluluğunun kendi tarihi tekâmülü hususunda sahip olduğu şuur demektir; o surette ki, bu insan topluluğu bu tarihi tekâmül şuuruna atfen varlığını devam ettirme azmini gösterir ve gelişmesini sağlar." 6

Kültür kelimesi Türkçe' ye Latince kökenli "cultura" sözcüğünden girmiştir. Literatürde kültür üzerine farklı tanımlar görebilmek mümkündür. Kültür sözcügü; "ekin ekme, yetiştirme" anlamına gelmektedir. Nitekim kültür tıpkı bir tohum gibi ekilerek kök vermektedir. Genel bir ifadeyle kültür; "Belirli bir toplumda ya da toplulukta yetişen insanların öğrendikleri beceri, dil, inanç, davranış ve alışkanlıklarımızdır." Kültür insanların doğdukları ve büyüdükleri yere, bölgeye, ülkeye göre değişiklik göstermektedir. Toplumların bir çoğunun gelenekleri, görenekleri ve hayat tarzları birbirini asla tutmamaktadır. ${ }^{7}$

Kültür konusunda en yetkin isimlerden olan Raymond Williams, kültür kavramına yaklaşımını da dikkat çekecek olursak; kültür, teknolojik gelişmelerle şekillenmektedir. Örf, adet, gelenek gibi soyut değerlerin yanı sıra teknik icatların ortaya çıkışı da kültüre etki etmiştir. Williams'a göre kültürü tanımlarken, belirleyici olan nesnelerin; tek bir güç ya da güçlerin soyutlanması olarak düşünmek yerine, aynı zamanda belirleyici faktörler olan; kapital dağılımı, sosyal mirası, sınırlar içerisindeki hareketleri denetleyen bir süreç olarak düşünmek daha doğru olacaktır. ${ }^{8}$

$\mathrm{Bu}$ bağlamda kültür, üretim ve dağıtım ile her türlü bilgi sisteminde yenilik yaşadığımız bu dönemde eski terimleri de aşmak şartıır ${ }^{9}$

Belirtildiği üzere, kültür kavramının farklı tanımları yukarıda ifade edildiği şekillerde açıklanmakta ve tanımlanmaktadır.

\footnotetext{
${ }^{5}$ Aziz Çalışlar, Ansiklopedik Kültür Sözlüğü, Altın Kitaplar Yayın Evi, 1993, S: 271

${ }^{6}$ Nevzat Köseoğlu, Milli Kültür ve Kimlik, İstanbul, 1992, S:147

${ }^{7}$ Temel Britannica, S:172

${ }^{8}$ Raymond Williams, Televizyon, Teknoloji ve Kültürel Biçim, Dost Yayınları, Ankara, 2003, S:108

${ }^{9}$ Raymond Williams, i̇kibin'e Doğru, Ayrıntı Yayınları, İstanbul, 1989, S: 124
} 


\subsubsection{Halk Kültüirü}

Halk kültürü; kaynağını halkın kendisinden alan ve halkın kendi yaşam biçimini yansıtan kültürel faaliyet biçimine verilen addır. Bir toplumun geçmişten günümüze sosyal ve kültürel yaşamını alan ve gelecek nesillere aktaran kültür biçiminin bir başka ifade edilişs şekli de halk kültürü olarak nitelendirilebilir.

\subsubsection{Halk Kültürü̈nün Sözlü ve Yazılı Kaynakları}

Mitler, efsaneler, masallar, halk hikayeleri, tekerlemeler, atasözleri, bilmeceler, deyimler, şarkı ve türkü sözleri, alkışlar, şakalar, incitmeler, atışmalar, alaylar, selamlar, vedalaşma sözleri, kişi, hayvan ve yer adları ile mani, ninni, ağıt gibi halk şiiri ürünlerinden oluşan sözlü kaynaklar vardır. Yazılı olanlar ise semai, gazel, rubai vb. kaynaklardır. ${ }^{10}$

\subsubsection{Kitle Kültürü ve Kültür Endüstrisi}

Kitle kültürü kitle üretimi yapan bir endüstriyel yapının yarattığı maddeci hayatı gerçekleştirme ve bu gerçekleştirmenin maddeci ve düşünsel biçimidir. Standartlaşmış kitle üretim biçimi ve tekniklerini, örgütlerini ve kitle tüketicisini gerektirir. Kitle kültürü seri üretimin sonuçlarından biridir ve kitle toplumundan önce var olmamıştır. Kitle toplumu üzerine de inşa edilmemiştir: Kitle toplumunun ticarileşmiş halidir. Günümüzde kitle kültürü kitle iletişimi araçları ve bu araçların desteklediği küresel pazarın mal, hizmet ve ideolojisiyle birlikte düşünülür. Kitle kültürüyle biçimlendirilen dünya kapitalist üretim tarzının egemenliğindeki bir uygarlığı temsil eder. ${ }^{11}$

Kültür endüstrisi terimi ilk defa 1947 'de, Amsterdam'da Adorno' nun Horkheimer' le birlikte yayımladığı Aydınlanmanın Diyalektiği adlı eserde kullanıldı. Müsveddelerde "kitle kültürü” terimi kullanılmıştı fakat daha sonra, yandaşlarının işine gelecek yorumları dışarıda bırakmak amacıyla kitle kültürü yerine "kültür endüstrisi" terimini kullanılması uygun bulunmuştur. Kültür endüstrisi eski olanla tanıdık olanı yeni bir nitelikte birleştirir. Kitlelerin tüketimine göre düzenlenen ve büyük ölçüde o tüketimin yapısını belirleyen ürünler, tüm alanlarda az çok bir plana göre üretilir. Tüm alanlar yapısal olarak benzerdir ve en azından

\footnotetext{
10 http://halkkulturu.nedir.com/, (20.03.2015)

${ }^{11} \mathrm{http}: / /$ www.irfanerdogan.com/makaleler1/popne.htm, Eğitim Dergisi, 2014, (20.03.2015)
} 
birbirinin açıklarını kapatarak, neredeyse tamamen gediksiz bir sistem oluştururlar. Bunu olanaklı kılan sadece çağdaş teknik olanaklar değil, aynı zamanda ekonomik ve yönetsel yoğunlaşmadır. Kültür endüstrisi, kasıtlı olarak tüketicileri kendisine uydurur. Kültür endüstrisi, yöneltilmiş olduğu milyonların bilincini ve bilinçaltını yönlendiriyor olmasına rağmen, kitleler birincil değil, ikincil role düşerler ve hesaplanabilir nesneler haline gelirler. Tüketici, kültür endüstrisinin bizi ikna etmeye çalıştığ gibi hükmedici ya da özne değil, aksine nesnedir. Özellikle kültür endüstrisi için biçimlendirilmiş olan kitle iletişim araçları terimi, vurguyu nispeten zararsız bir alana kaydırmakta çok işe yaramıştır. Gerçekte ne öncelikle kitlelerle, ne de iletişim tekniklerinin gelişsimiyle bir ilgisi vardır, aksine onları dolduran ruhla, sahiplerinin sesiyle ilişkilidir. Kültür endüstrisi kitlelerle ilişkisini kötüye kullanarak, verili ve değişmez sayılan bir zihniyeti çoğaltmaya ve güçlendirmeye çalışır. Her ne kadar kültür endüstrisi kitlelere uyum sağlamadan var olamayacak olsa da, kitleler onun ölçütü değil ideolojisidir. ${ }^{12}$

Bir başka açıklamada ise kültür endüstrisi, mevcut kapitalist sistemin kar elde etme kaygısına yönelik, kültürel üretimin oluşmasına yakından bağlı olarak gelişmiş; kültür ürünlerinin yeniden üretiminin bir tezahürü olarak karşımıza çıkmış bir kavramdır. ${ }^{13}$

Kültür Endüstrisi kısaca kitle kültürünün yeniden üretilmiş halidir. Kitle kültürü; kitle üretimi yapan bir endüstriyel yapının ortaya çıkardığı, maddi yaşamı realize etmede karşımıza çıkan düşünsel ve materyal kültür biçimidir.

\subsubsection{Frankfurt Okulu}

Frankfurt Okulu, esas olarak birçok biçimde yorumlanmakta ve açıklanmakta olan toplumsal düşünce tarzına uygun olarak gelişmiş bir eleştirel teori okuludur. 1923 yılında Toplumsal Araştırma Enstitüsü olarak ortaya çıkmış 1970'lere kadar etkin olmuş bir düşünce okuludur. Bu okulun öncüleri; Theodor W.Adorno, Max Horkheimer, Herbert Marcuse ve Jurgen Habermastır. ${ }^{14}$

\footnotetext{
${ }^{12}$ Theodor W. Adorno, Kültür Endüstrisini Yeniden Düşünürken, Bülent O. Doğan(çev.), Cogito, 2003, s:1

${ }^{13}$ Aziz Çalışlar, Ansiklopedik Kültür Sözlüğü, S:282

${ }^{14}$ Tom Bottomore, Frankfurt Okulu, Çev: Ahmet Çiğdem, Vadi Yayınları, 1994, s:7-10
} 
Frankfurt Okulu'nun ve Toplumsal Araştırma Enstitüsü'nün tarihi genel olarak üç döneme ayrılabilir: 1930-1936 arası olan birinci dönem, Enstitü direktörü olan Horkheimer'in başlattığı araştırma programının egemenliğiyle nitelenebilir. Ampirik araştırmalar aracılığıyla eleştirel bir toplum teorisinin geliştirilmesi ve bu sayede kolektif bir çalışmanın ürünü olarak ortaya çıkan "Otorite ve Aile" başlıklı eserdir. İkinci dönem ise yine Horkheimer imzalı, "Geleneksel Teori ve Eleştirel Teori" adlı eserdir. Üçüncü dönem ise, Kültür Endüstrisi teorisinin ortaya atıldı̆̆ 1 "Aydınlanmanın Diyalektiği"dir. ${ }^{15}$

Frankfurt okulunun tutumu, Marksist bir bakış açısıyla ancak bunu "epeyce gözden geçirilmiş bir Marksizm" olarak belirtmekte fayda vardır. Bu nokta da okul, Marksist düşüncenin tüm çeşitlerinde bulunan temel üst yapı modelinin, modern tarihsel gelişmelerin anlaşılması açısından yetersiz olduğu kanısına varmış ve Marksizm'i eleştirmiştir. ${ }^{16}$

Frankfurt Okulu özellikle; kültür, kitle kültürü, kültür endüstrisi, popüler kültür gibi kavramların bilinmesi açısından oldukça önemli yer tutan bir düşünce okuludur.

\subsubsection{Kültürr Endüstrisine Eleştirel Bakış Açısı}

Kültür endüstrisi tarafindan üretilen ürünler kişinin var olan düzeni kabullenmesini ve onunla bir bütün olmasını sağlayarak, kişiyi çepeçevre sarmaktadır. Bunun özünde de kitle kültürünün oluşturmuş olduğu kitlesel tüketim aracılığı ile kişi sürekli olarak yanlış gereksinimlerin etkisi altına alınmaktadır. Dolayısıyla eleştirinin ilki tüketim yoluyla bireylerin katı bir denetim içinde tutulmasına vurguda bulunmaktadır. Bu anlamda kitle kültürü ve onun tarafından üretilen kültür endüstrisi, kişinin sahip olduğu toplumsal statü ve rolü ile bir arada olan gereksinimler düzeyi belirleyerek kişinin hangi metaları tüketmesi gerektiğini sembolik biçimde belirtmektedir. Kültür endüstrisi daha önce de belirtildiği üzere, statükonun yeniden üretilmesinden ibarettir. Bu sebeple de toplumdaki eşitsizlikleri onaylar. Geçmişte insanlara hitap eden kültürel alanlar farklılaşmıştır. Burjuva toplumlarında yüksek kültür ve eğlence kültürü arasında kesin çizgilerle bir ayrım vardır. Kitle toplumunda ise yüksek kültür, eğlence kültürüne ve popüler kültüre karıştırılarak tamamıyla kitlesel ve ticari bir hale dönüştürülmüştür. Kültür endüstrisi esas olarak, bireye belli bir yaşam alanı tanıyor

\footnotetext{
${ }^{15}$ Mehmet Küçük, Medya İktidar İdeoloji, Bilim ve Sanat Yayınları, 2006, S:245-246

${ }^{16}$ Mehmet Küçük, Medya İktidar İdeoloji, S:246-247
} 
gibi görünse de aslında onların bireyselliklerine temelden karşı çıkmaktadır. $\mathrm{Bu}$ anlamda bireysellik denetlenen bir mekanizma haline gelmiştir. Kişiye ancak kurulu düzenin işleyişine mani olmayan son derece sığ bir alanda farklılaşma imkanı tanımaktadır. Sonuçta kişi, hem sistemin gücü ile özdeşleşmesine hem de onun tarafından yönetilmesine izin vermektedir. ${ }^{17}$

\subsubsection{Popüler Kültür}

Popüler kültür en basit tanımıyla gündelik yaşamın kültürüdür. İnsanların gündelik gereksinimleriyle örtüşen ve bunlarla beraber var olan bir kültür öğesidir. Popüler kelimesinin günümüzde kullanıldığı biçimiyle iki temel anlamı vardır. Hakim olan birinci tanımda popüler, "yaygın olarak beğenilen, tüketilen" anlamında kullanılmaktadır. İkinci tanımda ise popüler kelimesi popüler kültür-yüksek kültür tartışmalarından yola çıkılarak "halka ait" anlamıyla ele alınmaktadır. ${ }^{18}$

Popüler kültür, gündelik yaşama hakim kültür olarak karşımıza çıkar. Popüler kültürü yöneten sınıfların kültürel değerleri ve gelenekleri egemen ideolojileri doğrultusunda yeni formüller biçiminde yansıtarak yarattıkları bağımlı bireylere sundukları kültür olarak tanımlanabilir. ${ }^{19}$

Modern dönemde popüler kültür, içinde taşıdığg umut ve geleceğe yönelik beklentileri ile var olan sistem ve onun toplumsal formasyonu tarafından kuşatılmıştır. Özellikle 19.yüzyıldan itibaren popüler kültür, yeni bir toplumsal ve kültürel ortamda yaşamaya başlamış ve günümüze kadar ulaşmıştır. ${ }^{20}$

\subsubsection{Popüler Kültür Kavramı}

Popüler kültür kavramı, ilk olarak Amerika' da kitle kültürü olarak tartışılmış; elit kesimin kültürüne karşı halkın kültürünü karşılamak için üretilmiştir. 19. Yüzyıl sonlarından itibaren endüstriyel gelişmelere paralel olarak kapitalizmde ciddi bir ivme kazanmıştır.

\footnotetext{
${ }^{17}$ Theodor Adorno, Minima Morallia (Çev. Orhan Koçak, Ahmet Doğukan ), Metis Yayınları, İstanbul, 1998 den Akt: Mustafa Kemal Şen ve İsmail Hira, Frankfurt Okulu ve Kültür Endüstrisi Eleştirisi, Politika Dergisi, 2011

${ }_{18}$ Meral Özbek, Popüler Kültür ve Orhan Gencebay Arabeski, İletişim yayınları, İstanbul, 2002' den akt: Şadi Can Saruhan ve Ata Özdemirci, Kurum, Ürün ve Marka İmajının Oluşmasında Popüler Kültürün Yeri ve Önemi: Çok Partili Dönemin Yükselen Sektörleri Üzerine Geçmişe Yönelik Bir İnceleme,1950-1980

${ }^{19} \mathrm{https} / / /$ www.academia.edu/9881624/DEDE_N\%C4\%BONE_TORUN_KU\%C5\%9EAKLAR_ARASI_\%C3\%87ATI\%C5\%9EMALAR DA_POP\%C3\%9CLER_K\%C3\%9CLT\%C3\%9CR_, (20.03.2015)

${ }^{20}$ Ayşe Koncavar, Modern Dönemde Kitle iletişim Araçlarında Mitoslar, Pales Yayınları, İstanbul, 2014, S: 24
} 
Amerika en hızlı kapitalist değişimi yaşayan ülkelerin başındadır ve kapitalizmin eğlenceden müziğe, giyimden sanata hatta spora her alanda kendine bir sektör oluşturmaya başlaması nedeniyle, popüler kültür kavramı da orada kullanılmaya başlanmıştır. Popüler "halka ait olan" anlamına gelirken zamanla bu anlamın dışında "birçok kimse tarafından tanınmış, kabul görmüş olan” anlamında kullanılmaya başlanmıştır. ${ }^{21}$

Popüler sözünün bizdeki kullanımı Batıdan gelir ve oldukça yenidir. En popüler yanlış-anlamalardan biri de popülerin popüler olan tanımıdır. Popülerin dil bilimsel temeli ve tanımlaması geç-ortaçağ dönemindeki "halkın" anlamından, bugünkü egemen "birçok kişi tarafından sevilen veya seçilen" anlamına gelişmiştir. Bu kavramsal evrim sivil toplumun evrimine oldukça yakından tekabül eder. Burjuva demokrasilerinin yükselmesiyle ve bu demokrasilerin popüler seçim bağımsızlığına dayanan meşruluk iddiasıyla ve bunun siyasal alandaki ifadesi olan seçim süreciyle birlikte popüler teriminin belli bir anlamı ortaya sürülmüsşür. Bu anlamla popüler yönetici etkinliklerin ve programların (tv programları dahil) kabul damgası olmuştur. Popüler teriminin bu tür anlamı tek başına ve değişmez olarak yönetmez, aksine sürekli olarak değişmektedir; zaman zaman kültürel ve askeri popüler başkaldırılar tarafından tehdit edilmektedir. Popülerin bu egemen kullanılışı popüler alandan kültürel alana da yayılmıştır; bu egemen tanımı yeni alanlara taşıyarak, yeni ifade biçimleri vererek ve toplumsal sistem için yeni dayanak rolü sağlayarak devam etmiştir. Örneğin popüler televizyon programı, popüler film yıldızı, popüler sporcu, ve genel olarak popüler ve pop kültür gibi. Bu egemen popüler tanımı aynı zamanda "halkoyu" fikri arkasında saklanan haklı çıkarmadır. Halk oyunun tarihi de burjuva egemenliğinin desteklenmesinde aktif ve verimli süreçten, pasif, negatif, "sessiz çoğunluk", tüketim yönelimli desteğe dönmüştür. Popüler kavramı üzerinde, "halkın" ile "birçok kişi tarafından sevilen veya birçok kişinin favorisi olan" arasında, tutulan karmaşıklık, sadece masum yanlış anlamadan veya geçmiş tarihin hareketine bağlı fikirlerin karmaşıklığından değildir. Bugün "halk" terimin belli kültürel, siyasal ve toplumsal fikirlere, belli halkın fikri ve bilincine ve sonuçta halk ne idi, nedir, ne olabilir veya ne olacak fikrine bağlamak yararlıdır. ${ }^{22}$

\footnotetext{
${ }^{21}$ Melek Coşgun, Popüler Kültür ve Tüketim Toplumu, 2012, S:839' den akt: Dilşad Asena Ünkaracalar, Dede-Nine Torun Kuşaklar Arası Çatışmalarda Popüler Kültür, S:1

22 İrfan Erdoğan ve Korkmaz Alemdar, Popüler Kültür ve İletişim, Ankara, 2005, 2. baskı, S: 29-30
} 
Popüler kültür olgusu, insanoğlunun tarihinde eskiden beri görülen bir olgu olarak yeniden önem kazanmıştır. Tarihi olarak nitelendirildiğinde kent devletinden sonraki Mısır'ın, Sümer'in, Asur'un, Roma'nın gevşek dokulu geniş siyasal dünyalarının düzenlediği toplumsal hayata kazanan bir geçmişi vardır. Sulama kanallarının yapılması; kentlerin etrafındaki surlar ve hisarların yapılması; ticari ve askeri amaçlı bölgelere dinlenme ve bakım merkezlerinin yapılması vb...Ortaçağ da dahil olmak üzere bir popüler kültür olgusundan bahsetmek mümkündür. ${ }^{23}$ Kilise "babalarının" feodal toplumun sonunu getirecek sınıfın geliştiği 13.yüzyıl sonlarından iki yüz yıl kadar sonra Paris'in şiirini yazan François Villon' un şiirinde de bir "popüler kültür" dünyası vardır. Kent yaşamının hem çekiciliği hem de yaşam olanaklarının paylaşım adaletsizliği Rönesans öncesi toplumsal-kültürel yaşam içinde Villon'un şiirlerini oluşturmuştur. Kuşkusuz popüler kültür bugün tarihin eski dönemlerinden farklı bir biçimde vardır. İçindeki ileriye dönük umutları ve beklentileri bir açıdan her zamankinden daha canlı; bir açıdan ise umut ve beklentileri, ekonomik düzeyin etkin işleyişi devam ettiği sürece, var olan toplumsal sistem tarafından kuşatılmış olarak yer alır. ${ }^{24}$

Popüler kültür alanındaki yeni gelişmeler, geleneksel toplum yapısının zamanında kentlerin, kasabaların farklı kültürden gelme değişik insanların oluşturduğu etkinliklerden çok, daha teknolojiye dayanan eğlence biçimlerine geçilmiş; serbest zaman düzenlemeleri değişmiştir. Buna bağlı olarak, iletişim biçimleri yenilenmiş; ideoloji düzeyindeki düzenlemeler, devletin arkaya çekilmesi ile birlikte, sivil toplumun çok değişik kesimlerinde işletilmeye başlanmıştır. "Popüler kültür" de bunlardan biri olarak ortaya çıkmıştır. İnsanı, günlük yaşamın kazandırdıklarını yetersiz saydıracak bir beklentiye eriştirmeyi zaten başat kültür amaçlamamaktadır. Lakin, içten içe, bunun kişisel psikolojiye yansımaları olmakta, yetersizlik ve ezilmişlik duygusu, toplumsal yaşama karşı ilgisizlik duyulmaktadır. ${ }^{25}$ Popüler kültür, tam burada işlev görmektedir. Gerçek yaşamı fantazyada da aynı ile tekrarlayarak, gerçek yaşamın sürdürülmesini kolaylaştırmakta; yerine başka türlü bir yaşam olabileceğini

\footnotetext{
${ }^{23}$ Ünsal Oskay, Yıkanmak İstemeyen Çocuklar Olalım, "Popüler Kültürün Toplumsal Ortamı ve ideolojik işlevleri Üzerine", Yapı Kredi Yayınları, İstanbul, 1998, S: 245-246

24 Ünsal Oskay, Yıkanmak İstemeyen Çocuklar Olalım, "Popüler Kültürün Toplumsal Ortamı ve Ideolojik Işlevleri Üzerine", S: 248

25 Oskay, a.g.e.,259-260
} 
düşünmenin yollarını tıkamakta; bu kırgınlıkları, var olanı benimsemenin acısını ve utancını hafifletmektedir. ${ }^{26}$

\subsubsection{Popüler Kültüre Farklı Yaklaşımlar}

Popüler kültür, üzerinde çokça çalışma yapılan ve disiplinler arası bir olgu haline gelen bir unsur olması itibari ile birtakım farklı yaklaşımları üzerinde toplamıştır.

David Rowe'un popüler kültür dediği şey; folk ya da kitle kültürü gibi rakip formülleştirmelerle karıştırılmamalıdır. Folk kültürü, en iyi metalaştırılabilir olmayan ve rasyonelleştirilmemiş kültür biçimlerinin aşınmasıyla tahrip edilen ve özünde endüstri öncesi (kapitalizm öncesi olan), simgesel pratikler dizisi olarak nitelendirilmektedir. Bu bağlamda, "popüler" düşüncesi, resmi ve popüler olan arasında ya da Hall'un ifadesiyle "halk" ve "iktidar bloğu" arasında doğrudan bir ayrım önererek "halka ait" şeylere, aktörlere ve kurumlara gönderme yapar. Popüler kültür, kişisel ve davranışsal politikayla, estetik hitapla ve kültürel iktisatla bağlantıya geçen, çağdaş haz, aylaklık, üslup ve kimlik biçimleri olarak çeşitli yollardan ortaya çıkan ve değişen, toplumsal ve kültürel ilişkiler anlamlar ve metinler dizisi olarak görülmektedir. Popüler kültüre, kültür üretiminin endüstriyel süreçleri, popüler kültür metinlerinin anlamları, popüler söylemlerin ideolojileri ve kültürel metaların verdikleri hazlar ve kullanımları dahil olmak üzere, birçok yoldan yaklaşmak mümkündür. Popüler kültüre ilişkilerin değerlendirilmelerin birçoğunda üstü kapalı ya da bariz olarak sorulan temel soru, çeşitli biçimleri içerisinde popüler kültürün, modern kapitalist toplumların hegemonik tahakküme direniş olarak mı, yoksa çanak tutma olarak mı nitelendirilebileceği sorusu olmuştur. $^{27}$

John Fiske' in popüler kültüre olan yaklaşımı da şu şekildedir; popüler kültür, tüketim değildir, kültürdür toplumsal bir sistem içerisinde anlamları ve hazları yaratan, onları dolaşıma sokan bir süreci kapsamaktadır. Kültür, endüstrileştirilmemiş de olsa, metaların alınıp satılması çerçevesinde kolayca betimlenemez. Kültür yaşayan, canlı bir süreçtir. Yalnızca kendi içinden gelişip boy atabilir, dışarıdan ya da yukarıdan dayatılamaz. ${ }^{28}$ Popüler kültürü üreten halktır, kültür endüstrisi değil. Popüler kültür, gündelik yaşam ile kültür

\footnotetext{
${ }^{26}$ Oskay, a.g.e., S:262

27 David Rowe, Popüler Kültürler (Rock ve Sporda Haz Politikası), Ayrıntı Yayınları,İstanbul, 1996, S: 21-22

28 John Fiske, Popüler Kültürü Anlamak, Ark Yayınları, Ankara, 1999, S: 35
} 
endüstrileri ürünlerinin arasındaki ortak kesimde halk tarafından oluşturulur. Popüler kültür halk tarafından oluşturulur, onlara dayatılamaz; yukarıdan değil, içeriden ve aşağıdan doğar. Popüler kültür, sistemin sağladıklarıyla idare etme sanatıdır. ${ }^{29}$ Popüler kültürde endüstrileşen iş bir kültürdür. Popüler kültürün yaratıcılığı, metaların üretiminde değil, endüstriyel ürünlerin üretken kullanımında yatmaktadır. Böyle bir kültürde halkın sanatı "elindekiyle yetinme" sanatıdır. ${ }^{30}$ Gündelik hayatın kültürü, kapitalist sistemin sağladığı kaynakların yaratıcı, beğeniye dayalı kullanımında yatmaktadır. Demek oluyor ki, kültürel metaların popüler olabilmeleri için birbirleriyle çelişkili olan ihtiyaçları karşılamaları gerekmektedir. İnsanların gündelik yaşamı, kapitalist toplumların çatışmalarını çıkar çatışmalarının sürekli pazarlık konusu edildiği ve rekabet içinde bulunduğu yerdir. ${ }^{31}$

Hakim popüler kültür diye bir şey olamaz, çünkü popüler kültür daima hakimiyeti altına alma güçlerine karşı gösterilen tepki tarafından biçimlendirilir, bu sebepten de asla hakimiyet altına alma güçlerinin bir uzantısı değildir. Bu iddia, hakim toplumsal grupların üyelerinin popüler kültüre katılamayacaklarını belirtmemektedir, katılabilirler ve katılmaktadırlar da. Lakin bunu yaparken, toplumsal dayanışmalarını, kendilerini toplumsal iktidarlarına veren yerden uzakta yeniden oluşturmaları gerekmektedir. Örneğin; bir futbol maçında, arkadaşlarıyla birlikte özel locada eğlenen bir işadamı popüler kültüre katılmamaktadır, ancak aynı işadamı iş kıyafetlerinden sıyrılarak desteklediği takımın forma renklerini kuşanıp takımını en ucuz tribünden izleyerek alkışlıyorsa işte o zaman popüler kültüre katıllyordur. Ancak, popüler kültüre katılmak için muhtemelen öteki toplumsal dayanışmalara da dahil olması gerekmektedir. İşadamının beğenileri ve kültürleri bireysel değil toplumsaldır. Bir toplum aktörü olarak; oluşturduğu dayanışmaları çevreleyen toplum düzeni üzerinde olmasa bile, dayanışmaların kendileri üzerinde belli bir ölçüde denetim uygulanabilir. ${ }^{32}$ Popüler kültür her zaman kendisini (ekonomik, ideolojik, ya da disipline sokan nedenlerden ötürü) denetlemeye çalışanlar için güç koşullarla çevrili olan dağlık bir bölgedir. Bu kültürün gerilla okumaları sistemin yapısal bir zorunluluğudur. Endüstrilerin

\footnotetext{
29 John Fiske, Popüler Kültürü Anlamak, Ark Yayınları, Ankara, 1999, S: 38

30 John Fiske, Popüler Kültürü Anlamak, S: 40

${ }^{31}$ Fiske, a.g.e., S: 46

32 Fiske, a.g.e.,S: 59-60
} 
ekonomik gereksinimleri, popüler kültüre uygun kaynaklar olarak seçmeleri durumunda giderilebilir. ${ }^{33}$

Ünsal Oskay' a göre de popüler kültür şu kavramlarla belirtilmiştir. Kitle kültürü ile popüler kültür kavramlarını aynı toplumsal ve kültürel olgulara aitmiş gibi kavramlar kullanıldıkça, kültür hayatımıza giderek endüstrinin denetimi altına girdiği bu düzende ilerleyen dönemde de etkisini git gide arttıracağı ve önüne geçilmez bir hale bürüneceği açıkça görülmektedir. ${ }^{34}$ Popüler kültür, yeterince homojenleştirilememiş toplumlarda, tek bir kalıba dökülememiş toplumlarda meydana gelir. $\mathrm{Bu}$, iki durumda mümkündür. Ya, sanayi kapitalizminden önceki dönemlerin toplumlarında ya da aşırı homojenleştirilmenin insanlarda yaşama şevki bırakmayacağı yerleşim yerlerine ya da üretkenlik düzeyi yüksek, "demokratik" örgütlenmelere, kültür hayatındaki farkl1lıklara tahammül edebilen gelişmiş ülkelerde. ${ }^{35}$ İlk durumda, yani sanayi öncesi dönemde popüler kültürün yaşama olanağı bulabilmesi bu toplumların üretkenliğinin yüksek oluşundan değil; kültürel ve siyasi donanımlarının yeterince güçlü olmayışından kaynaklanmaktadır. Aynı durum, ana hatlarıyla sanayi devrimi sonrası toplumsal örgütlemelere de devam eden bir süreci kapsamaktadır. ${ }^{36}$

Gramsci' nin yaklaşımı ise, popüler kültüre olumsuz yaklaşan "Frankfurt Okulu” ile popüler kültüre olumlu yaklaşan "kültürelciliği” birleştirmiştir. Buna göre popüler kültür ne yapısalcı ekolün gördüğü gibi halkın kültürel deformasyonu ne de kültürelcilerin gördüğü gibi kendini doğrulama, kendini yapma olarak görülür. Popüler kültür, karşıt baskılar ve eğilimler tarafından biçimlenen "güç alanı" ilişkileri olarak nitelenir. Gramsci kapitalizm içindeki mücadelenin egemenlikten çok hegemoni için mücadele olduğunu ileri sürer. Ona göre burjuvazi, burjuva ideolojisinin karşıt sınıfın kültürleri ve değerleri içinde bulduğu yer ölçüsünde hegemoni kurabilir. Burjuva egemenliği, işçi sınıfının kültürünü değiştirerek veya onu yok ederek değil; işçi sınıfının burjuva kültürü ile birlik olmasıyla güvence altına alınabilir. Böylece hem burjuva hem de işçi sınıfı kültürleri tamamı ile birbirine karşıt iki grup olarak düşünülmez. Yani popüler kültür, ne egemen ideolojiyle çatışan, empoze edilmiş kitle kültüründen ne de karşıt kültürlerden oluşmaz. Popüler kültür iki sınıf arasında pazarlık

\footnotetext{
33 Fiske, a.g.e., S: 131

34 Ünsal Oskay, Yıkanmak İstemeyen Çocuklar Olalım, "Kitle Kültürü Popüler Kültürü Kuşatırken", Yapı Kredi Yayınları, İstanbul, 1998, S: 151

35 Ünsal Oskay, Yıkanmak İstemeyen Çocuklar Olalım, "Kitle Kültürü Popüler Kültürü Kuşatırken", S: 153

36 Oskay, a.g.e., S: 154
} 
sahasıdır. Bu sahada egemen ve alttaki karşıt kültürel, ideolojik değerler ve elemanlar farklı karışımlar içinde bulunurlar. Bir kültürel pratik kendi politikasını sanki alnına yazılmış gibi kendisi taşıyamayıp, o pratiğin siyasal fonksiyonu, belli bir ortamda diğer pratiklerle anlamlandırılması sonucu olarak içinde yazıldığı toplumsal ve ideolojik ilişkilere bağlıdır. Kültürel pratiklerin siyasal ve ideolojik eklemleri sabit değil, değişkendir. ${ }^{37}$

Stuart Hall'un değerlendirmesiyle de popüler kültür: İktidarda olanların kültürüne karşı ya da onun adına mücadelenin alanlarından biri olarak ifade edilir. Esasında o mücadele alanı, kaybedilecek ya da kazanılacak bir şeydir. Direnme ve boyun eğme alanlarıdır. Hegemonya'nın kısmen de olsa güvenlik altına alındığı bir yerdir. Hall'a göre popüler kültür bu hususlarda önemlidir. ${ }^{38}$

Frankfurt Okulu teorisyenlerine göre de popüler kültür: Burjuvanın, siyasi ve iktisadi yaşamı temelinde ilerleyen ideolojik bir üst yapı kurumudur. ${ }^{39}$

Görüldüğü üzer popüler kültüre pek çok farklı yaklaşımlar mevcuttur. Özellikle kültürel çalışmalar başlığı altında popüler kültür çok önemli bir yere sahip olmakla birlikte akademik literatüre değişik çalışma prensipleri getirme gereği duyulmuştur.

\subsubsection{Popüler Kültür ve Toplum}

Günümüzde gelişmiş ve gelişmekte olan ülkelerde, iki ayrı kültür ortamı iç içe oluşturulmakta ve insanlar bu iki ayrı kültürü iç içe yaşamaktadır.

Bunlardan ilki, başka insanlarla kurulan ilişkilerde yalnızca "av ya da avcı" konumlarının olabileceği inancını, eşitsizliği, özel mülkiyeti, değişim değerinin her türlü değerin ölçütü olduğu inancını bütün insanlara empoze eden ve benimseten kitle kültürüdür. Kitle kültürünün bu değerleri, toplumun farklı kesimlerinin zaman zaman birlikte yer aldıkları, birbiriyle karşılaştıkları alanlardaki kültürün değerleri ile özdeştir. Kitle kültürünün tüketicisi konumunda olmamızın nedeni, anlaşıldığı üzere, yaşadığımız gerçek toplumla ilişkilerimizle onu kabullenerek hatta ona boyun eğerek yaşantımızın içinde kabul

\footnotetext{
${ }^{37}$ Erdoğan ve Alemdar, Popüler Kültür ve İletişim, 1994, S: 104-107, Meral Özbek, Popüler Kültür ve Orhan Gencebay Arabeski, İstanbul, İletişim Yayınları, 2000 S: 66-69 dan Akt: Hasan Hüseyin Özkan, Popüler Kültür ve Eğitim, Kastamonu Eğitim Dergisi, S:29-38

${ }^{38}$ Stuart Hall, Notes on the Deconstucting the Popular, Curan, j.et.al. Çev. Meral Özbek, 1981, S:239

${ }^{39}$ Veysel Batmaz, Medya Popüler Kültürü Gizler, Karakutu Yayınları, İstanbul, 2006, S:95'den Akt. Petek Durgeç, Popüler Kültür Bağlamında Mizah Dergilerinin Değişen İşlev: Penguen Dergisi, Yayınlanmamış Yüksek Lisans Tezi, S: 38
} 
etmemizdir. Popüler kültür, üretildiği ve tüketildiği ancak henüz kendi denetimi altına alamadığı yaşam alanlarında, örneğin toplumun "hafta sonları" dediğimiz kültürel etkinlik zamanlarında (pop müzik konserleri, popüler televizyon programları, futbol -basketbol müsabakaları) gibi etkinlikler, "çekilebilmek" yani gündelik hayatın sıkıntılarından kurtulmak adına bir rahatlama hissine kapılma durumunu ortaya çıkarmaktadır. ${ }^{40}$

İletişim teknolojisindeki büyük ilerlemelerin geniş kullanım alanı oluşturması, popüler kültür yaratma bağlamında önemli etkiler yaratmaktadır. Popüler kültür, bu teknolojik çoğaltma ortamında kendini gösteren ve hızla yaygınlaşan bir olgu olarak dikkat çekmektedir. Dolayısıyla, popüler kültürün şekillenmesi, iletişim teknolojisi ve bu teknolojinin yarattığı hızlı iletişim ve yoğun etkileşimine bağlıdır. Bu nedenle hızlı iletişim ve yoğun etkileşimin yapılandırdığı toplumsal özelliklerin verilmesi, konunun anlaşılması bakımından büyük önem arz eder. Günümüz toplumunun, belirtilen en genel özelliği, bir gösteri toplumu oluşudur. Önemsenen her kuramcı ve düşünür değerlerin, kurumların, insani ilişkilerinin sahneleştiğini ve sanallaştığını vurgulamaktadır. Günümüzde düşünce ve sanat, eğlence tarafından yeniden üretilmektedir. İnsanlar, düşünmek ve sorgulamaktan ziyade görmeyi istemektedir. Haber programları ile siyasal açık oturumlar bile, araya giren reklamlar ve sunucuların tavırları dolayısıyla gerçeğin araştırıldığı yapımlar olmaktan çıkıp, neden sonuç ilişkilerinin görünmez kılındığı, sadece katılanların kişisel beceri ve sevimliliklerini sergilemeye uğraştıkları gösterilere dönüşmektedir. ${ }^{41}$

$\mathrm{Bu}$ gösteriler sembolik olarak, çağdaş tahakküm kazanmış durumdadır. Medya tarafından belirlenen imge ve gerçek arasındaki ilişki öyle birbirine geçmiştir ki, aralarına bir çizgi çekmek neredeyse imkânsız hale gelmiştir. Jean Baudrillard, son zamanlarda ortaya çıkan bu yenilikleri biraz olumsuzlukla, kuşkuyla karşılar ve daha fazla medyanın, daha fazla enformasyonun kisvesi altında gizlenmiş, daha az anlam olduğunu öne sürer. Jean Baudrillard'a göre, içinde yaşadığımız postmodern toplum her şeyden önce bir tüketim toplumudur. Taklidin hâkim olduğu bu toplumsal düzlemde, önceden tasarlanmış tüketim nesneleri ve biçimleri bulunmaktadır. Taklit ve tekrarla üretilen postmodern kültür, göz kamaştırıcı bir şekilde gerçek üstü bir toplumsal düzeni yapılandırmaktadır. Bu toplum,

\footnotetext{
40 Oskay, A.g.e S:155-156

${ }^{41}$ Ahmet Oktay, Postmodernist Tahayyüle İtirazlar, İnkılap Yayıncılık, İstanbul, 2000 dan Akt: Ünal Şentürk, Popüler Bir Kültür Örneği Olarak Futbol, C.Ü. Sosyal Bilimler Dergisi, 2007, S: 32
} 
tüketime kodlanmış ve programlanmış, kendi kendini tüketerek denetleyen bir mekanizmayla varlık kazanmaktadır. ${ }^{42}$

$\mathrm{Bu}$ noktada Herbert Marcuse'nin mevcut sistemin tüm bireyleri birbirine benzeterek "tek boyutlu" kıldığını belirtmesi dikkat çekicidir. Şöyle ki Marcuse; insanların kendilerini, satın aldıkları metalarla tanıttıklarını, ruhlarını otomobillerinde; müzik setlerinde, mutfak eşyalarında bulduklarını belirtmiştir. Ayrıca, bireyi topluma bağlayan düzeneğin kendisinin değiştiğini ve toplumsal denetimin üretmiş olduğu yeni gereksinimlerle kendilerini demirlediklerini ifade ederek, insanların tek boyuta indirgenmesinden dolayı sahte ihtiyaçların varlığının oluştuğunu ve bu noktada yeni bir kültür ortaya çıktığını savunmuştur. ${ }^{43}$

Günümüz toplumunu, fazla ve lüks tüketim olgusu karakterize etmektedir. Temel ihtiyacı aşacak biçimde yapılan her türlü fazla harcama lüks olarak nitelendirilmektedir. Lüks veya fazla tüketim, yaşanılan sistem ve süreç ile yakından ilgilenmektedir. Nitekim, gereğinden fazla tüketim içinde yaşanılan süreç içinde yeni tüketim araçlarıyla teşvik edilmektedir. ${ }^{44}$ Yeni tüketim araçları (restaurantlar, reklam, popüler kültür, hipermarketler, eğlence merkezleri, showroomlar, v.b.), daha büyüklükte ve çoğu zaman ihtiyacımızdan fazla tüketim yapmak için insanları zorlamaktadır. Yeni tüketim araçlarının etkileri o boyutlarda ki, bu araçlar, insanların ihtiyacı olan şeyler konusunda "yardımcı olan” kitle iletişim araçlarının önemli unsuru olan reklamlar, bir taraftan insanların ihtiyacından fazla tüketim yapmasına neden olurken, diğer taraftan tüketimin, insanlara statü sağlamanın tek yolu olduğu izlenimini vermektedir. İnsanlar, ihtiyacı olduğundan veya zengin olduklarından değil, toplum içinde statünün, artık tüketim ile kazanılması nedeniyle, harcama yapmaktadır. Konu bu noktaya gelince, tüketim gerçekliği ile ilişkisini kaybetmekte ve gösterişli yaşam alışkanlığını ortaya çıkarmaktadır. Bu bağlamda, herhangi bir şeye sahip olmak, onun maddi değerinden fazla bir anlam taşımaktadır. $\mathrm{Bu}$ nedenle de insanın harcama yapması ile gelir seviyesi arasındaki anlamlı ilişki ortadan kalkmaktadır. Yani insanlar, gelirlerinden, ekonomik imkânlarından daha fazla tüketim yapmaya yönelebilmektedir. Alain Touraine, kültürel unsurların ve malların kitlesel olarak üretim ve dağıtımın belli bir merkezden gerçekleştirilmesine bağlı

\footnotetext{
${ }^{42}$ Werner Sombart, Aşk, Lüks ve Kapitalizm, Çev.Necati Ara, Bilim ve Sanat Yayınları, Ankara, 1998'den akt. Şentürk, S:33

${ }^{43}$ Herbert Marcuse, Tek Boyutlu İnsan(ileri İşleyim Toplumunun İdeolojisi Üzerine İncelemeler, çev. Aziz Yardımlı, İdea Yayınları, 1986, S: 8

${ }^{44}$ Werner Sombart, Aşk, Lüks ve Kapitalizm, (Çeviren: Necati Ara), Bilim ve Sanat Yayınları, Ankara, 1998 dan Akt: Şentürk, S: 33
} 
olarak, günümüz toplumunu “programlanmış toplum” olarak niteler. Ona göre, kanaat, tutum, davranış, kişilik ve kültürün bilinçli olarak yönlendirilmesi ve yönlendirme işleminde değerlerin kullanılması, topluma programlanmış bir özellik kazandırmaktadır. Touraine, Sanayi toplumundan programlanmış topluma geçişin, "şeylerin" idaresinden insanların yönetimine geçiş olduğu üzerinde durur. ${ }^{45}$ Dolayısıyla tüketim, gösteri, reklam ve eğlenceyle koşullandırılan bir toplumsal dizge, benzer özellikleri içeren bir kültür yaratmaktadır. $\mathrm{Bu}$ kültür, bazı özelliklerini de futbolda gösterir.

$\mathrm{Bu}$ bilgiler 1şı̆̆ında popüler kültür ve toplum ilişkisinin birbirinden bağımsız düşünülemez olduğunun sonucuna varılmıştır. Çünkü bir toplum olmadan, onu ifade edebilecek bir kültürün varlığından söz edemeyiz. Modernite adını verdiğimiz bu süreçte popüler kültürün, topluma olan yansımaları belirgin bir şekilde görülmekte ve teknolojik gelişmeler doğrultusunda varlığını arttırarak sürdürmektedir.

\subsubsection{Popüler Kültürün Genel Özellikleri}

Popüler kültürün en temel özelliği uzun ömürlü olmamasıdır. Böylece popüler ürünlerin seri bir biçimde tüketilmesi ile birlikte yeniden üretilmesini beraberinde getirmektedir. Popüler kültür asla yerinde saymaz ve sürekli değişim, gelişim göstermeyi gerektirir. Bir nevi kendini yenileme gereği duymaktadır. Örneğin; sürekli yeni filmlerin vizyona girmesi, yeni televizyon programlarının yayınlanması ve yeni kitapların basılması, bireylerin değişen eğilimleri doğrultusunda popüler kültürün şekillenmesi ile ifade edilmektedir. Popüler kültür, kapitalizm tarafından sağlanan kültürel kaynaklar ile gündelik yaşam arasında ara kesimde üretilir. Kültürel kaynak, gündelik yaşam tecrübelerinin kendisiyle birlikte var olmasını olanaklı hale getirecek bağlantı noktaları önermiyorsa, popüler olamaz. Gündelik yaşam, sürekli değişen toplumsal dayanışmalar aracılığı ile akışkan bir biçimde yaşanıp öyle tecrübelendiği için, bu bağlantı noktalarının da türlü türlü olmaları toplumsal belirlenmelere açık ayrıca da geçici olmaları zorunludur. ${ }^{46}$

Popüler kültür doğası gereği, kitle iletişim araçlarından yoğun bir biçimde faydalanmaktadır. Kitle iletişim araçlarının kısa sürede geniş bir kesime yayılması, bireylerin

\footnotetext{
${ }^{45}$ Alain Touraine, , Modernliğin Eleştirisi, 4. Baskı, (Çeviren: Hülya Tufan), Yapı Kredi Yayınları, İstanbul, 2002 den Akt: Şentürk, S: 34

46 Fiske, $159-160$
} 
çabuk etkilenmelerini sağlamaktadır. Dolayısıyla bireyler yönlendirmekten ziyade yönlenen konumuna geçmektedir. Tam bu noktada popüler kültür devreye girer. Bu doğrultuda popüler kültürün kitle iletişim araçlarını efektif bir şekilde kullanması, en etkili özelliklerinden biridir. Popüler kültürün genel nitelikleri şöyle sıralanabilir; formüller ve tekrarlarla standartlaşmıştır, daha çok isteklerin gerçekleştirilmesini ön plana çıkartır, halk kültüründen farklı olarak, popüler kültür onu kullanan toplum tarafından üretilen kültürel kaynaklardan oluşmaz, sadece ürün tüketilmez aynı zamanda insanın kendiyle ve başkalarıyla olan ilişkisel anlamlar tüketilir, üretilir ve son olarak gösteriş, imajlar özün üstüne geçer. ${ }^{47}$

Yaşamın hangi zamanını, yerini ve ifade şeklini alırsa alsın, popüler kültürün içeriği üretim ve kültür endüstrileri tarafından belirlenir ama popüler kültür bu endüstrilerin ve ürünlerinin toplamı değildir. Bunların ve toplumun sürekli etkileşiminin bir ürünüdür. $\mathrm{Bu}$ etkileşimde üretim araçlarında ve kolektif üretim bağlamında egemenliği ellerinde tutmaları sebebiyle belli bir sınıf belirleyici ve yönetici konumundadır. İster popüler, ister kitle ya da halk kültürü olsun, ister somut ister soyut bir düşüncenin üretimi olsun, kültürle üretilen, belli biçimdeki yaşam ve bu yaşamın ideolojisi ve bilincidir. Yaşamın ideolojisi ve bilincinin üretimi de, popüler kültürün üretim özellikleriyle beraber gider, onun tarafindan belirlendikten sonra, onunla etkileşime başlar. $\mathrm{Bu}$ etkileşim sürecinde, sadece egemen kültürler yeniden-üretilip sürekliliği sağlanmaya çalışılmaz, aynı zamanda, karşıt olan kültürler üretilir ve mücadele verirler. Dolayısıyla, kültür alanı insan yaşamının tümünü kapsayan egemenlik ve mücadele alanıdır. ${ }^{48} \mathrm{Bu}$ noktada dikkatimizi çeken en önemli unsurların başında, kuşkusuz kültürün yeniden üretiminin ne kadar etkin bir hale büründüğü gerçeği yatmaktadır.

\footnotetext{
47 İrfan Erdoğan, "Popüler Kültürde Gasp ve Popülerin Gayri Meşruluğu”, Doğu Batı Dergisi, 4. Sayı, 2001, Ankara, S: 65-106 48 http://www.irfanerdogan.com/makaleler1/popne.htm, 20.03.2015
} 


\section{BÖLÜM: OYUN NEDİR?}

\section{1. "OYUN" KAVRAMI}

Öncelikle oyun; eğlenceyi, ciddiyetten uzaklaşmayı, keyifli vakit geçirmeyi aklımıza getiren sosyal hayatın önemli unsurlarından biri olarak tanımlanmaktadır. Oyuna bireyi iten, tanınma isteği, rahatlama ihtiyacı, yeni bir faaliyeti deneme arzusu ve sosyalleşme isteği gibi nedenlerdir. Oyunun başka bir şekilde ifadesi ise yaşam enerjisinin fazlalığını tüketme yolu, doğuştan var olan yeteneklerin ortaya çıkışını sağlaması, kötü ve zararlı alışkanlıklardan kurtulma yolu, insanın doyuma ulaştıramadığı bazı ihtiyaçlarını kurmaca ile gidermesi ve bireysel hazzı sağlaması olarak tanımlanabilir. ${ }^{49}$

Oyun, köklü bir tarihe sahiptir. İnsanlar, geçmişten günümüze hayatta kalma mücadelesi verirken aynı zamanda farklı hazları doyurma ihtiyacı duymuşlardır. Bu hazların giderilmesi de kuşkusuz kurmaca bir dünyada yaratılan etkinliklerin uygulanması ile mümkündür. $\mathrm{Bu}$ bağlamda oyun hem bir ihtiyaçtır hem de hayatla birlikte var olan çok önemli bir olgudur.

\subsubsection{Oyunun Genel Özellikleri}

Gönüllü bir etkinliktir. Asla bir görev değildir. Emirlere bağlı oyun olmaz. Oyun ancak kültürel bir işlev haline geldiği zaman zorunluluk, görev ve ödev kavramları ona dâhil olmaktadır. Kalıcı olmayan bir faaliyet alanıdır. Kendi kurmaca dünyasını yaratır. İhtiyaç ve arzuların dolaylı olmayan haz mekanizmalarının dışında yer alır ancak hayattan kopmaz, ona eşlik eder. Kişi açısından biyolojik işlev olarak ve topluluk açısından da içerdiği anlam, yarattığı manevi ve toplumsal yakınlık, kısacası kültür işlevi olarak vazgeçilmez özelliğe sahiptir.Herhangi bir çıkarı yoktur. Oyunun amaçları dolaysız maddi çıkar veya bireysel açlıkların tatmini alanının dışında yer almaktadır. Yalın ve sınırlı bir faaliyettir. Önceden belirlenmiş zamanda ve mekânda sonuna kadar oynanır. Tekrarlanabilir ve yeniden kurgulanabilir.Belli başlı kuralları ve düzeni vardır. Kurallar ihlal edilmemelidir. Ayrıca oyun

\footnotetext{
49 http://mimesis-dergi.org/2011/05/oyunun-tanimi-ve-toplum-yasantisindaki-yeri/, (04.04.2015)
} 
düzeninin nitelikleri bazı estetik unsurlara benzer: ritim, armoni, heyecan, belirsizlik, denge, tezatlık, gösteriş, çeşitleme, birbirine eklenme, ayrılma, çözüm... ${ }^{50}$

Oyunun kavramı ve genel özellikleri başlıca bu ifadelerle açıklanabilir. Tüm bu bilgiler doğrultusunda oyun sadece bir etkinlik değil aynı zamanda kültürel bir öğedir.

\subsection{BİR KÜLTÜR ÖĞESİ OLARAK OYUNUN ANLAMI}

Homo Ludens kavramı "oyun oynayan insan", teriminden gelmektedir. İçerik, derinlemesine bir incelemeye tabi tutulduğu zaman, insanın bütün yapıp etmelerinin yalnızca oyundan ibaret olduğu sonucuna da varılabilir. ${ }^{51}$

Oyun, genel itibariyle kültürden daha eskidir. Nitekim, kültür kavramını ne kadar daraltsak da, bu kavram her koşulda bir insan toplumun varlığını gerektirir ve hayvanlar kendilerine oyun oynamalarını öğretmesi için insanın gelmesini beklememişlerdir. Hayvanlar da aynı insanlar gibi oyun oynarlar. Oyunun bütün temel çizgilerini incelemek için, yavru köpeklerin neşeli oynamalarını dikkatlice gözlemlemek yeterli olacaktır. ${ }^{52}$ Burada, çok önemli bir noktayı belirtmek gereklidir. Oyun, en basit biçimlerinde ve hayvan hayatının içinde bile, tamamen fizyolojik bir olgudan ya da fizyolojik olarak belirlenen psişik bir tepkiden daha fazla bir şeydir. Oyun, biyolojik veya fiziksel bir faaliyetin sınırlarını aşmaktadır. Oyun, anlam bakımından zengin bir işleve sahiptir. Oyunda yaşamın doğrudan ihtiyaçlarını aşan ve eyleme anlam katan bağımsız bir unsur vardır. Her oyunun bir anlamı vardır. Eğer, oyuna bir öz yükleyen bu faal ilkeye zihin dersek aşırıya kaçmış oluruz; içgüdü dersek hiçbir şey söylememiş oluruz. Hangi açıdan ele alınırsa alınsın, oyunun bu "kasıtlı" karakteri, bizzat özünün içinde yer alan maddi kaygı taşımayan bir öğenin varlığını açık etmektedir. Psikoloji ve fizyoloji, oyunu hayvanlarda, çocuklarda ve yetişkin insanlarda gözlemek, betimlemek ve açıklamak için çaba göstermektedir. Bu bilim dalları, oyunun doğasını ve manasını saptamaya ve onun hayatındaki yerini belirlemeye çalışmaktadır. $\mathrm{Bu}$ yerin önemi, oyunun yerine getirdiği işlevin gerekli veya hiç değilse yararlı karakteri, genel

\footnotetext{
50 http://mimesis-dergi.org/2011/05/oyunun-tanimi-ve-toplum-yasantisindaki-yeri/, (04.04.2015)

51 Johan Huizinga, Homo Ludens Oyunun Toplumsal İşlevi Üzerine Bir Deneme, (çev. Mehmet Ali Kılıçbay), Ayrıntı Yayınları, İstanbul, 2010, S:13-14

52Johan Huizinga, Homo Ludens Oyunun Toplumsal İşlevi Üzerine Bir Deneme, (çev. Mehmet Ali Kılıçbay), S:16
} 
olarak ve çelişkisiz bir şekilde her bilimsel araştırma ve incelemenin hareket noktası olarak kabul edilmiştir. ${ }^{53}$

Yapılan diğer araştırmalara göre ise; oyunun kökeninde, hem hakimiyet kurma isteği hem de yarışma gereksinimi içinde, bir şey yapabilmeyi veya bir şeyi belirleyebilmeye yönelik olan kendiliğinden yatkınlık da bulunmaktadır. Bazı diğer kuramlar oyunu, zararlı yönelimlerinden masum bir şekilde kurtulma yolu olarak kabul etmektedirler; yani bunlara göre oyun, ya fazlasıyla tek taraflı olarak harekete geçmeye yönelten bir yönelimin zorunlu telafisidir ya da gerçek hayatta gerçekleştirilmesi olanaklı olmayan isteklerin bir kurmaca aracılığıyla giderilmesi ve böylece kişisel bir aidiyet duygusunun sağlanmasıdır. $\mathrm{Bu}$ tanımlamaya göre de, getirilen her açıklama karşısında, şu soru geçerliliğini korur? Sonuçta oyunun "zevk veren" tarafı nedir? Oyuncunun neden hırstan gözü döner neden binlerce kişi, kalabalık futbol maçında çılgınlığa varan bir heyecan yaşar? ${ }^{54}$

Oyunun yoğunluğu yapılan hiçbir biyolojik inceleme tarafından açıklanabilmiş değildir ve zaten oyunun özü, tamamen onun kökeninde yer alan yanı tam da bu yoğunlukta, bu aşırı tahrik etme gücünde bulunmaktadır. Oyunun özüne tekrar indiğimiz zaman; doğa bize oyunu, heyecan, sevinç ve neşesiyle birlikte vermiştir. Oyunun "zevkli yanı" tüm çözümlemeleri ve mantıksal yorumlamaları reddeder. Bu doğrultuda, oyunda hayatın herkes tarafından hemen tanımlanabilen temel bir kategoriyle karşı karşıya kalmaktadır. Oyunu, kelimenin modern anlamında bütünsellik olarak adlandırılması mümkündür ve oyunu bütünselliği içinde kavramak ve değerlendirmek gerekmektedir. ${ }^{55}$

Oyunun varlığı bizim evren içindeki konumumuzun mantık üstü karakterini sürekli ve en yüksek anlamıyla ortaya koymaktadır. Hayvanlar oyun oynayabilirler. Demek ki sadece mekanik şeyler olmanın çok ötesindedirler. İnsanlar da oyun oynuyor ve oynadıklarının bilincindeler. Demek ki insanlar da sadece akıllı varlıklar olmanın ötesindeler çünkü oyun irrasyoneldir. Ayrıca oyunun kültürü içinde de bizzat kültürden önce var olan, kültüre eşlik eden ve kültüre başlangıcından itibaren içinde yaşadığımız döneme kadar etkisi altına alan, bir nesne olarak buluruz. ${ }^{56}$

\footnotetext{
53 Huizinga, a.g.e., S: 17

54 Huizinga, a.g.e., S: 18

55 Huizinga, a.g.e., S: 19

56 Huizinga, a.g.e., S: 20
} 
Oyunun bir başka dikkat çekici unsuru ise; hayatta karşılaştığımız birçok temel kategori, ciddi olmayan içinde yer almasına rağmen, oyunla eşdeğer bir biçimde gülmez. Gülme bazı noktalarda ciddiyetin karşıtıdır, ama oyunla hiçbir şekilde doğrudan bağlantısı yoktur. Şöyle ki; çocuklar, "futbol" veya satranç oyunlarını, akıllarından asla gülme isteği geçmeden, derin bir aidiyet içinde oynarlar. Nitekim, tamamen fizyolojik olan gülme işlevinin sadece insana özgü olmasına karşılık, yaratıcı oyun işlevinin insan ile hayvanda ortak olarak bulunması ilginçtir. ${ }^{57}$

Oyun, en gelişmiş biçimiyle doğal olarak insana bahşedilmiştir. Estetik algılama yeteneğinin en soylu unsurlarını meydana getiren ritim ve armoni ile bir bütün halindedir. $\mathrm{Bu}$ sebeptendir ki, oyun ile estetik ve güzellik arasında sıkı bir bağ vardır. Oyunun güzelleşmesi ve estetik hale gelmesi insani davranışların gelişmiş bir biçimde ortaya çıkmasıyla mümkün hale gelir. Bu bağlamda oyun kavramı, manevi ve toplumsal hayatın yapısını ifade edebildiğimiz diğer bütün düşünce biçimlerinden farklılığını dikkat çekici bir şekilde korumaktadir. ${ }^{58}$

Esasında her şeyden evvel oyun bireylerin isteklerine bağlıdır. Emirlere bağlı oyun, özelliğini yitirir. Oyundan alınan haz, oyunu ihtiyaç olarak hissettirdiği ölçüde, oyunun gerekliliği emredici hale gelmektedir. Oyun her an ertelenebilir veya iptal edilebilir. Oyun, fiziksel bir ivedilik veya ahlaki bir ödev tarafından dayatılmış bir olgu kesinlikle değildir. Oyun, bir görev değildir,"serbest zaman" içinde gerçekleştirilen bir etkinlik alanıdır ancak oyun, kültürel bir işlev haline geldiği zaman zorunluluk, görev ve ödev kavramları ona dahil olmaktadır. Dolayısıyla burada oyunun ilk temel çizgisi ortaya çıkmaktadır. Oyun serbesttir, oyun özgürlüktür, oyun "gündelik" yahut "asıl" hayat hiç değildir. Oyun, bu hayattan kaçarak, kendine özgü eğilimleri olan geçici bir faaliyet alanına girme bahanesi sunmaktadır. ${ }^{59}$

Oyun kendi içinde ele alındığında, bize en azından gündelik hayatın içinden bir kesinti, bir rahatlama meşguliyeti olarak gözükmektedir lakin oyun düzenli olarak tekrarlanan bu özelliğiyle bile, genel anlamdaki hayata eşlik etmekte, onun bir bütünleyicisini, hatta bir parçasını meydana getirmektedir. Oyunun, birey açısından biyolojik işlev olarak ve topluluk

\footnotetext{
${ }^{57}$ Huizinga, a.g.e., S: 22

58 Huizinga, a.g.e., S: 24

59 Huizinga, a.g.e., S: 25
} 
açısından da içerdiği anlam, ifade değeri, yarattığı manevi ve toplumsal bağlar, kısacası kültür işlevi olarak vazgeçilmez niteliktedir. ${ }^{60}$

Oyunun amaçları, dolaysız maddi çıkar veya bireysel açlıkların tatmini alanının dışında yer alması da dikkat çekilmesi gereken önemli bir husustur. Oyun başlar, belli bir süre geçtikten sonra biter. Oyun süresince hareketler, gidiş gelişler, birtakım değişiklikler, birbiri yerine geçmeler, bağlanmalar ve ayrılmalar görülür. Oyunun zamansal olarak sıralanmasına örnek başka bir özellikte de doğrudan bağlanır. Oyun, hemen kültürel bir biçim olarak belirlenir. Bir kez oynandıktan sonra, hafızalarda manevi bir değer veya hazine olarak kalır, aktarılır ve her an tekrarlanabilir. Tabi tüm bunları önceden belirlenmiş mekansal alanın sınırları içinde gerçekleştirir. Arena, oyun masası, sihirli çember, oyun sahası, tapınak; bunların hepsi biçim ve işlev açısından oyun sahasıdır. Yani tahsis edilmiş, ayrılmış, çevresine parmaklık çekilmiş ve kendi sınırları içinde özel kuralların uyulması gerektiği yerlerdir. Bu oyun ayrıca bir düzen gerektirir. Bu düzenin en küçük ihlali oyunu bozar, oyun niteliğini ve değerini zedeler. ${ }^{61}$ Her oyunun kendi kuralları olur. Bunlar, oyun tarafından çizilen geçici dünyanın çerçevesi içinde neyin yasa gücüne sahip olacağını belirler. ${ }^{62}$

$\mathrm{Bu}$ veriler doğrultusunda oyunu biçim açısından, kısaca şöyle tanımlamak mümkündür. Olağan hayatın dışında yer aldığı hissedilen, özgür ve "kurmaca" ama yine de oyuncuyu tamamen içine çekme yeteneğine sahip bir eylemdir. Örneğin; Çocuk, oyun oynamakta ve oyun oynadığını bilmektedir. Sporcu inançlı bir ciddiyet içinde ve heyecanın verdiği atılganlıkla oynamaktadır. Aktör, kendini oyununa kaptırmıştır ve bunun bilincincedir. Kemancı en kutsal heyecanı duymaktadır; alışılmış dünyanın dışında ve üstünde bir dünyada yaşamaktadır ancak faaliyeti bir oyun olarak kalmaktadır. "Oyunsal" karakter, en yüksek etkinliklere bağlı olarak kalmayı sürdürebilir. ${ }^{63}$

\footnotetext{
60 Huizinga, a.g.e., S: 26

${ }^{61}$ Huizinga, a.g.e., S: $27-28$

62 Huizinga, a.g.e., S:29

63 Huizinga, S:37-38
} 


\subsubsection{Huizinga' nın Oyun Kavramına Yöneltilen Eleştiriler}

Huizinga kuşkusuz oyun kavramının özellikle kültürel bir olgu çerçevesinde açıklanmasında ve anlaşılmasında en önemli isimdir ancak bu konuya eleştirel bakış açısıyla yaklaşmak konunun içeriğinin zenginleşmesi ve daha iyi anlaşılır bir nitelik kazanması adına önemli bir yere sahiptir. Bu bağlamda iki isim önemlidir. Bunlar; Jacques Ehrmann ve Eugen Fink' tir.

\subsubsection{Jacques Ehrmann' in Eleştirisi}

Fransız Kuramcı, J.Ehrmann (1931-1972)'a göre oyun, Huizinga' nın aksine dış gerçeklikten soyutlanmış bir olgu değildir. Huizinga' nın oyunu kavramsallaştırması, oyunun bir kültürü yansıtan ve kültürün içerisinde anlamlandırılması gereken bir şey olduğunu gözden kaçırmaktadır. Oyunun gerçeklikten arınmış, gerçekliğin ise arılığı kirletilmiş bir oyun olduğu kabul edilemez ancak Ehrmann' a göre bu tanımlama ideolojik bakımdan açık bir taraflılık taşımaktadır. Oyun da dahil gerçekliği oluşturan kültürel unsurları, gerçekliğin kendisinden sonra ve ondan ayrı meydana gelmiş nesneler olarak düşünmemek gerekir. $\mathrm{Bu}$ noktada oyun, kültür ve gerçeklik birbirinden ayrılmazlar. Bu kavramlar, birlikte oluşmuş ve karşılıklı etkileşim içinde olan olgulardır. ${ }^{64}$

Her şeyden önce Huizinga' da belirli bir biçimde var olmuş olan şey, bir kültürel gerçeklik yani oyun, kendinden sonraki toplumsal gerçekliklere oranla değişim göstermez. İstikrarlı ve üstün bir gerçeklik olarak meydana gelir. Oysa ki oyunun dışında ve öncesinde oluşmuş bir diş gerçeklik ya da kültür yoktur ve olamaz. Böyle bir "oyun" kavramsallaştırılması doğru olamaz. Daha önce bahsedildiği üzere oyun, gerçeklik ve kültür birlikte oluşmuşlardır. Ehrmann' a göre oyun; Huizinga' nın kavramlaştırdığının aksine kültürün bizzat içinde yer alan ve kültürün bütünlüğünü yansıtan, kendisinden farklı diğer kültürel faaliyetlerde görülen pek çok davranışlar gibi bir davranış tarzıdır. ${ }^{65}$

Başka bir ifade ile Ehrmann, Huizinga' nın oyunu "hayatın pazar günü" olarak kavram haline getirmesi ve bu anlamda bir oyunu modern toplumlarda bulamayışının yanlışlığını

\footnotetext{
64 Jacques Ehrmann, "Homo Ludens Revisited" Jacques Ehrmann (Ed.), Game Play, Literature, Boston, 1968, ss. 31-38 'den Akt: Ünsal Oskay, XIX. Yüzyıldan Günümüze Kitle İletişiminin Kültürel İşlevleri, Der Yayınları, İstanbul, 2010, S:162

65 Jacques Ehrmann, "Homo Ludens Revisited" Jacques Ehrmann (Ed.), Game Play, Literature, Boston, 1968, ss. 31-38 'den Akt: Ünsal Oskay, XIX. Yüzyıldan Günümüze Kitle İletişiminin Kültürel İşlevleri, Der Yayınları, İstanbul, 2010, S:162-163
} 
göstermiş olmaktadır. Oyunun bir şey üretmediğine bakarak, Huizinga' nın yaptığı gibi oyunu ciddi olan etkinliklerin dışında ve onların karşısında bir lüks, bir dinlenme unsuru, bir süs sayma yanılgısı oyunun yetersiz olarak kavramsallaşmasından dolayıdır. Ehrmann' in deyişiyle, "oyunun, toplumun ekonomik düzeyinde yapılmakta olan üretim sürecindeki işlerin dışında bir şey olduğunu sanmak" yanlış bir kavram olarak ortaya çıkmasına zemin hazırlamıştır. ${ }^{66}$

Yine Ehrmann' in düşüncesine göre oyunun, belli bir toplumsal yaşam içerisinde ritüelleri doğrultusunda kültürden ayrı bir olgu olmadığı, diğer tüm kültürel olgular gibi toplum hakkında, temel özellikte bilgiler aktaran bir iletişim biçimi olduğu anlaşılacaktır. Başka bir ifade ediliş şekliyle Ehrmann' ın bu eleştirisi, Huizinga' nın oyun ile oyun olmayanı ayrı yaşam alanları olarak düşünen ifadeleri aksine bugünkü toplumsal, ekonomik ve kültürel düzey ile etkin bir bütünlük olduğuna işaret etmektedir. ${ }^{67}$

\subsubsection{Eugen Fink 'in Eleştirisi}

Huizinga 'yı eleştiren bir başka yazar da Alman düşünür Eugen Fink (1905-1975)' tir. Fink' e göre, "oyun-olan" ile "ciddi-olan" içiçedir. Oyunun diğer kültürel unsurlara göre değerlendirmenin doğru olduğunu düşünmemektedir. Bu bağlamda, oyunun biçimlendirilmesi ve değiştirilmesi söz konusu olamaz. Aksine yaşanan belli bir toplumsal hayatın, gerçek yanlarını tamamlayan, onları temsil ettiği kendi düzenlemeleri içerisinde bir kurmaca niteliğinde ayrı bir olgu olarak algılanan ve özümsenen, gerçek yaşamın kurmaca niteliğindeki yanlarını belirli bir toplumsal formasyonun gereklerine uygun olarak bütünlüğe kavuşturan bir unsurdur. ${ }^{68}$

Oyunun sembolik niteliğinin iki taraflı bir karaktere sahip olduğunu söyleyen Fink, "Birincisinin, oyunun yaşanan gerçek dünyada oynanmakta oluşundan ve oynayan insanın, oyunu oynamakta olduğunu bilmesinden dolayı sahip olduğu özelliklerdir." İkincisi ise "Oyunun diğer insansal faaliyetlerinin oluşturduğu ciddi amaçlara göre alt konumda yer alışını belirtmektedir." Fink'e göre oyunun, kendinden başka bir kültür unsurunun bağımlısı

\footnotetext{
66 Jacques Ehrmann, "Homo Ludens Revisited" Jacques Ehrmann (Ed.), Game Play, Literature, Boston, 1968, ss. 31-38 'den Akt: Ünsal Oskay, XIX. Yüzyıldan Günümüze Kitle İletişiminin Kültürel İşlevleri, S:163

${ }^{67}$ Ehrmann, a.g.e., S:164

${ }^{68}$ Eugen Fink, "The Oasis of Happiness: Toward an Ontology of Play", Ehrmann po. cit., s. 22' den Akt: Ünsal Oskay, XIX.

Yüzyıldan Günümüze Kitle İletişiminin Kültürel İşlevleri, S:164-165
} 
olmaması, belirtilen bu ikili özelliğinden kaynaklanmaktadır. Böylece oyunu oynayan insan, aynı zamanda hem gerçek yaşamını sürdürebilmekte hem de oyun olanı bu yaşamında her mekanda oynayabilmektedir. Başka bir ifadeyle insan, oyundan türemiş ve bazılarına göre üst konumda sayılan oyun dişı diğer bütün kültürel faaliyetlerde aynı anda iki ayrı alanda yaşayabilmektedir. Bu iki yanlılı̆̆ kullanarak yaşayabilen insan hem gerçek dünyadan hem bir oranda ayrı olması onu tamamı ile göz ardı etmemesi sayesinde hiçbir canlıda yer almayan bir kabiliyete sahip olduğunu gösterir. Bu kabiliyet, insanın yaşadığı gerçek dünyadan istediği zaman, istediği derecede geri çekilebilme olanağı kazandırmakta; üstelik bu geri çekilmede gerçek dünya ile olan bağlantılarını koparmasına da gerek yoktur. Öte yandan da insanın gerçek yaşama hizmet ediyor oluşuyla belli bir toplumsal yapı ile bütünleşmesi kolaylaşır. ${ }^{69}$

Bu nedenlerden ötürüdür ki Fink' e göre oyun, her zaman kurmacanın bir ürünü olmakla birlikte hiçbir zaman sadece kurmaca niteliğinde bir faaliyet alanı değildir. Çünkü oyunu oynayanın oyun sırasında yaşadığı kendi özelliği ile, kendisini kuşatan somut dış dünya arasında bir yerde durabilmesini olanaklı kılmakta ve bireyin kendi öznelliğini ve gerçekliğini sürdürebilmesini sağlamaktadır. Bunun anlamı, oyunda oynanan dünyanın, insanın içinde yaşarken kendi varoluşuna anlam vermeye çalıştığı gerçek dünyanın sembolik bir biçimde yansıtılması oluşudur lakin oyunun oynanabilmesi için gerçek dünyadan geri çekilme yolu içine sığınılan dünyanın gerçekten ideal bir dünya değil, gerçek dünyadan uzak olsa bile bu gerçekliği göz ardı etmeyen bir dünya olması gerekmektedir. ${ }^{70}$

Tüm bu bilgiler doğrultusunda, oyunun bütünüyle yansıtmış olduğu dünya, gerçek dünyanın dışında olmayan bir dünyadır.

\subsection{OYUN KAVRAMININ DÍLDE İFADE EDILİŞI}

Oyun kavramının, alışıla gelmiş biçiminden, yani modern Avrupa dillerinin çoğunluğundaki gündelik kelimelerin bazı farklılıklarla beraber ifade ettikleri haliyle oyun kavramından yola çıkmak gerekmektedir. Bu kavramı şöyle sınırlandırmak mümkündür. Oyun, özgürce razı gelinen ama tamamen emredici kurallara uygun olarak belirli zaman ve mekan sınırları içinde gerçekleştirilen, bizzat bir amaca sahip olan, bir gerilim ve mutluluk

\footnotetext{
${ }^{69}$ Eugen Fink, "The Oasis of Happiness: Toward an Ontology of Play", Ehrmann po. cit., s. 22' den Akt: Ünsal Oskay, XIX. Yüzyıldan Günümüze Kitle İletişiminin Kültürel İşlevleri, S:165-166 70 Fink, a.g.e., S: 177
} 
duygusu ile "alışılmış hayat" tan "başka türlü olmak" bilincinin eşlik ettiği irade eylemi veya faaliyettir. Böylece açıklanan kavram, hayvanlar, çocuklar ve yetişkin insanlara ilişkin olarak oyun adını verdiğimiz her şeyi kapsamaya yakın hale gelmiştir: beceri, zeka, güç ve şans gösterileri gibi. Bütün halklar oyun oynar ve bu işi birbirlerine oldukça benzeyen biçimler şeklinde yaparlar ancak bütün diller oyun kavramını, modern Avrupa dillerinde olduğu gibi, aynı anda hem çok belirgin hem de geniş bir kitle içinde kavrayamazlar. Hiçbir insan topluluğu için, oyun kavramı, oyunu ifade etmek için sahip oldukları kelimenin ama bu aynı zamanda kelimeler de olabilir, ifade ettiğinden daha fazlasını içermez. Bir dilin, kavramın farklı özelliklerini tek bir kelimede, diğer dillerden daha iyi birleştirmiş olması her zaman mümkündür. ${ }^{71}$

Mitolojilerin hiçbirinde oyun tanrısal veya şeytani bir biçimde cisimleştirilmemiştir, ama bu mitolojilerde oyun oynayan bir tanrının temsil edilmesine siklıkla rastlanmaktadır. Genel oyun kavramının ortaya geç tarihlerde çıktığına ilişkin başka bir kanıt da şudur: Oyunu ifade eden hiçbir ortak Hint -Avrupa kelimesi yoktur. ${ }^{72}$

Oyun hakkında; Yunanca, Sanskritçe, Çince ve İngilizce olarak çeşitlik kelimelere rastlamak mümkündür. Yunancadaki "inda" eki, çocuk oyununu belirtmek üzere dikkat çekici bir ifade olanağı sunmuştur. Bu son ek çekimsizdir ve dilsel açıdan indirgenemez niteliktedir. Yunanlı çocuklar, sphairinda -top-, helkustinda -ip-, streptinda -çelik çomak-, basilinde küçük kral- gibi oyunlar oynamışlardır. Bu son ekin tam bağımsızlığında, herhalde sembolik olarak ifade edilen oyun kavramının indirgenemezliği yatmaktadır. ${ }^{73}$

Yunancada genel oyunsal alanı ifade etmek üzere en azından üç kelime kullanılmaktadır. Bu kelimenin etimolojisi açık bir biçimde ortadadır. Öncelikle, oyunu ifade etmeye en uygun olan paidia terimi vardır. Bu kelimenin etimolojisi açıkça ortadır. Terim çocuğa ait olanı işaret etmekte, ama çocuksuluk anlamına gelen paidia'dan vurgusuyla hemen ayrılmaktadır. Ayrıca, paidia gündelik kullanımı içeren çocuk oyunlarıyla asla sınırlı değildir. Kelime, paizen -oynamak, paigma ve paignion -oyuncak- gibi türevleriyle, daha önce gördüğümüz üzere, en soylularına ve kutsallarına varana kadar oyunsal biçimlerin bütün türlerini ifade edebilmektedir. Geriye, yine oyun alanına giren ama Yunanlılarda ne paidia'

\footnotetext{
${ }^{71}$ Huizinga, Homo Ludens Oyunun Toplumsal İşlevi Üzerine Bir Deneme, S: 50

72 Huizinga, Homo Ludens Oyunun Toplumsal İşlevi Üzerine Bir Deneme, S: 51

73 Huizinga, a.g.e., S:52
} 
nın de athurma' nın kapsadığı ve ifade ettiği, özellikle müsabakaları ve yarışları kapsayan çok geniş bir terminolojik alan kalmaktadır. Yunan hayatında büyük önem taşıyan agon kelimesidir bu. Agon Yunan kültüründe hayatın en önemli parçalarından biri olarak kabul edilir. Yunan hayatında rekabete yönelik yarışmaların sahip olduğu yeri gösteren agon, ister sadece Yunan kültüründe isterse tüm dünyada ele alınsın, oyunun bütün biçimsel niteliklerini taşımakta ve işlevsel olarak, öncelikli bir bölümü itibariyle şenlik alanına yani oyunsal alana aittir. $^{74}$

Sanskritçeye geldiğimiz zaman, oynamak için kullanılan en genel terim Kritadi' dir. $\mathrm{Bu}$ kelime, çocukların, yetişkinlerin ve hayvanların oyununu ifade etmektedir. Tıpkı Germanik dillerdeki karşılığı olan terim gibi, rüzgarın veya dalgaların hareketini belirtmektedir. Bu kelime, özellikle bir oyun kavramı içermeksizin, atlayıp zıplamak ve dans etmek konusundaki genel fikri de ifade edebilir. ${ }^{75}$

Oyun olarak gördüğümüz bütün faaliyetlerin tek bir isim altında birleştirilmesine Çinlilerde rastlanmaktadır. Özellikle müsabakaya ilişkin her şey için, Yunancanın agon' uyla kıyaslanabilir bir niteliğe sahip olan çang kelimesi ile, düzenlenen müsabaka fikrine özgü olan sai teriminden yararlanılmaktadır. Oyun kavramının kültürden bile eski olduğu belirtildiği zaman, zamanın akışı içerisinde farklı dillerde ne tür anlamlar taşıdığı dikkat çekici bir husustur. ${ }^{76}$

Daha yakın tarihte Germen, İngiliz ve Fransız dillerinde de oyunun çeşitli anlamlarına geldiğini belirtmek gerekmektedir. Germen dilinde oynamak ve oyun spelen ve spielen anlamlarını taşırken, İngiliz dilinde to play ve play, Fransız dilinde ise oyun (jeu) ve oynamak (jouer) anlamlarını ifade etmektedir. ${ }^{77}$

Oyunun nasıl kavrandığı farklı kültür ve dillerde ne şekilde ifade edildiği önemli bir yere sahiptir. Çünkü, oyunun evrensel bir yapıya sahip olması, her kültürün kendine özgü ifade edilişs şeklinin bilinmesi gereklidir.Gerek Çin, gerek Yunan, Fransız, Germen ve İngiliz kültürlerinde "oyun"un kavranmasını kısacası bu şekilde özetlemek mümkündür.

\footnotetext{
${ }^{74}$ Huizinga, a.g.e., S:53

75 Huizinga, a.g.e., S:53

76 Huizinga, a.g.e., S:54

77 Huizinga, Homo Ludens Oyunun Toplumsal İşlevi Üzerine Bir Deneme, S: 66
} 


\subsection{OYUNDA YARATICILIK}

Oyun hakkında geniş literatürde başlıca iki ekol vardır. Bunlardan ilki oyunu bilme etkinliğinin bir biçimi olarak değerlendirilir. Oyunlarda nasıl simgeler üretildiği ve bu simgelerin giderek nasıl karmaşık bir hale geldiği incelenir. Öteki ekol ise oyunu bir davranış biçimi olarak ele alır. ${ }^{78}$

Oyunun zıddı ciddi olan değil, gerçek olandır. Oyun konusundaki araştırmalarıyla Freud'un bu oyun-yaratıcılık ile gerçekliği karşı karşıya koyuşunu sorgulama noktasına gelenler argümanlarını genelde, zıt olmasa bile eş anlamlı terimlere ifade ederler. Oyun ve yaratıcılıktan gerçeklik üzerine değil, tümdengelim mantığından söz edilir. ${ }^{79}$

Oyunla ilgili olarak yapılan araştırmalarda edinilen bulgulara göre bir sorun da "yaratıcılık" terimidir. Çoğunlukla yaratıcılık ve oyun ilişkisini kuran teoriler, örneğin sanatçının eserinde bu sonuca hangi adımlarla ulaşıldığını ve bu sürecin oyun oynayanın içsel aktiviteleriyle ilişkisini açıklayamaması gibi. Oyun ve yaratıcı çalışmaya ilişkin teori geliştirmek önemlidir. Teori geliştirirken oyun faaliyetleri yaratıcı faaliyetlere hazırlık olarak görülmelidir. Oyundaki kendine özgü eylemlerle yaratıcı çalışmanın özgün biçimleri arasında mutlaka bir bağ kurulmalıdır. ${ }^{80}$

Oyunun kültürel işlevi dışında özellikle yaratıcılık konusunda ne gibi bir etkiye sahip olduğu düşüncesi, görüldüğü üzere farklı yaklaşımları beraberinde getirmiştir.

J.Huizinga , Homo Ludens incelemesinde belirtildiği üzere oyunu üç şekilde ele alabiliriz. Oyun, öncelikle tam bir gönüllü faaliyettir. Daha sonra "çıkar gözetmeyen" bir etkinliktir. Son olarak da oyun yalıtılmış ve sınırlı bir faaliyettir. ${ }^{81}$

Burada belirtilen durumlarda çıkar gözetmemek asla ilgisizlik anlamına gelmez. Oyun oynayan bireylerin sıkıldıkları ise nadir görülür. Huizinga çıkar gözetmemeyi anlık isteklerden ya da doyumlardan uzak durmak anlamında kullanmıştır. R.Sennett de bu durumu Huizinga doğrultusunda ifade etmiştir. Esas itibariyle bahsedilen bu uzak durma sayesinde,

\footnotetext{
78 Richard Sennett, Kamusal İnsanın Çöküşü, çev: Serpil Durak ve Abdullah Yılmaz, Ayrıntı Yayınları, İstanbul, 2013, S: 405

79 Richard Sennett, Kamusal İnsanın Çöküşü, çev: Serpil Durak ve Abdullah Yılmaz, S: 405

80 Sennett, a.g.e., S: 406

81 Sennett, a.g.e., S: 406
} 
insanlar birlikte oyun oynayabilmektedir. Çıkarsız oyun olgusu nitekim, yaşam döngüsünde insanlık tarihi kadar eski bir süreci kapsamaktadır. ${ }^{82}$

R.Sennett'e göre oyun, bireylerin üzerinde anlaşıp bilinçli olarak benimsedikleri eylem ilkeleriyle bir araya gelerek gerçekleştirdikleri bir faaliyet biçiminde tanımlanabilir. Oyunun toplumsal bir olgu olarak ortaya çıkması bireylerin içinde yaşadıkları farklı kültürlere bağlı olarak, farklı yaş dönemlerinde farklı kurallara bağlı olarak değişkenlik gösterebilir. ${ }^{83}$

Çoğu Batılı oyunlarında, mutlaka bir son, kazanmaya ilişkin bir kural ve Çin oyunlarında olduğu gibi oyunu bitiren bir kural olmalıdır. Zaten oyun sırasındaki özel kazanımlar dahil hep kazanmayı ve oyununu sonunu geciktirmeye ve heyecan katmaya yöneliktir. İster batılı oyunlar, ister Çin oyunları isterse de Modern Amerikan oyunları olsun, oyun oynanırken kuralların yumuşaklığg ve esnekliği toplumsal bir bağ oluşturur. Oynamak, bireysellikten özgürleşmeyi gerektirir ve bu özgürlük de belli başı kurallar aracılığı ile yarat1labilir. $^{84}$

Belli kurallar bütününe oturtulmuş oyun sistemi, asla kısıtlama değil aksine özgürleştirici bir özelliğe sahiptir. İster çocukluk isterse de yetişkin dönemler olsun oyun oynama işlevi gerçek anlamıyla sosyalleştirme ve kaynaştırma özelliğine sahiptir.

\subsection{KÜLTÜR İŞLEVİ OLARAK OYUN VE MÜSABAKA}

Kültür oyun biçiminde doğar, başlangıçtan itibaren oynanan bir şeydir. Örneğin av gibi doğrudan hayati gereksinimlerin giderilmesini hedefleyen etkinliklerde bile, eski topluluklarda kolaylıkla oyun biçimine bürünmektedirler. Toplumsal yaşam, oyunlar tarafından temsil edilen ve yüksek bir saygınlık kazandıran biyoloji üstü biçimler halinde ortaya çıkmaktadır. Topluluk, bu oyunlarda yaşamı ve dünya düzenini yorumlama biçimini ifade etmektedir. ${ }^{85}$

\footnotetext{
${ }^{82}$ Sennett, a.g.e., S: 407

83 Sennett, a.g.e., S: 408

${ }^{84}$ Sennett, a.g.e., S: 409

85 Huizinga, a.g.e., S: 70
} 
Demek ki, oyunun kültüre dönüştüğünü değil de, tamamen tersine, kültürün ilk aşamalarından itibaren bir oyunun çizgilerini taşıdığını ve oyun biçimleri altında ve oyun ortamında geliştiğini anlamak gerekir. Kültür ile oyunun bu ikili birlikteliğinde, oyun nesnel olarak gözlenebilen ve somut biçimde belirlenebilen revize unsuru meydana getirmektedir. Buna karşılık kültür, bizim tarihsel yargımızın kaynağı olan bir duruma atıfta bulunulan nitelemeden başka bir şey değildir. ${ }^{86}$

Kültürün gelişiminde, oyun ile "oyun olmayan" arasında kökeninden beri olduğu düşünülen ilişki değişime uğrar. Kültür doğal olarak, oyunsal öğeyi yavaş bir biçimde arka plana iter. Oyunsal özellik, artık tamamen kültürel olgular tarafından gizlenmektedir ancak oyunsal özellikler yine de, evrime uğramış kültürel bağlamlar içinde bile her zaman bütünüyle yeniden geçerli hale gelebilir ve bireyi de, kitleyi de devasa bir oyunun sarhoşluğuna sürükleyebilir. ${ }^{87}$

Oyun ile kültür ilişkisi, tüm bulgulardan anlaşıldığı üzere, özellikle toplumsal oyunun üst noktalarında yani bu oyunun bir topluluğun veya bir grubun yahut karşılıklı olarak iki grubun kurallı eylemleriyle bağlantılı olduğu yerde aranmaktadır. Bireyin tek başına oynadığı oyun, kültür için ancak sınırlı ölçüde yararlıdır. Daha önce de belirtildiği üzere oyunun, hatta grup halindeki oyunun bütün ana unsurları hayvanlar aleminde mevcuttur. (Mücadele, temsil, tahrik, gösteriş, taklit, kısıtlayıcı kural vb.) Bu bilgi ışığında şu örnek dikkat çekicidir. Dem çeken kuşlar danslar yapar, kargalar uçma yarışları düzenler ve güzel öten kuşlar melodi üretir. Demek ki, yarışma ve temsil, güzelce vakit geçirme şekli olarak, kültürden kaynaklanmamakta hatta ondan önce gelmektedir. ${ }^{88}$

Oyun; fiziksel, entelektüel, ahlaki veya soyut değerler sayesinde de kültür seviyesine yükselebilir. Oyun, bireyin veya grubunun hayat düzeyini yükseltmeye ne kadar yatkınsa, o ölçüde gerçekten kültür haline bürünür. ${ }^{89}$

Oyun ve müsabaka ilişkisi açısında değerlendirme yaptığımız zaman; kendi içinde ele alınan müsabakanın oyun kategorisine dahil edilmesi gerekmektedir. Müsabaka da, tıpkı diğer oyunlar gibi, belli bir noktaya kadar amaçtan yoksundur. Başka bir ifadeyle kendi içinde

\footnotetext{
${ }^{86}$ Huizinga, a.g.e., S: 71-72

${ }^{87}$ Huizinga, a.g.e., S: 71

88 Huizinga, a.g.e., S: 72

89 Huizinga, a.g.e., S: 72
} 
oluşmaktadır ve sonucu hiçbir şekilde, topluluk hayatının zorunlu akışının bir parçası değildir. Şu halk deyişi bu özelliği destekler bir nitelik taşımaktadır. Önemli olan kazanılan misketler değil, oyundur. Bunun da manası, eylemin nihai unsurunun öncelikle, ardından gelenle doğrudan ilişkisi olmayan başlangıcın içinde yer aldığıdır. ${ }^{90}$

Bir müsabakanın en önemli çıkış noktası kazanma olgusudur. Kazanma isteği ile oyun arasında çok sıkı bir bağ mevcuttur. Bireysel oyunda, oyunun amacına ulaşmak henüz kazanmak anlamına gelmez. Bu kavram ancak ve ancak, ötekine karşı oynandığı zaman işin içine dahil olmaktadır. Kazanmak, bir oyunun sonunda "üstünlügünü belli etmek demektir" ancak, sınırları iyice belli olan bu üstünlük, görünümüne bürünme eğilimi gösterir. Bu yüzden de, kazanmak oyunun sınırlarını aşar, itibar ve onur verici bir nitelik kazandırır. Böylece oyunun çok önemli bir biçimi ortaya çıkar. Burada kazanılan başarı, büyük ölçüde bireyden gruba aktarılabilir bir özelliktedir. ${ }^{91}$ Onur ve saygınlık, bu bağlamda uzun süreli sonuçlar doğurur ancak, olası bir durumda oyunun sınırlarının belli olduğu andan itibaren kazanma fikrine onurdan daha fazla bağlı olan bir etken ortaya çıkmaktadır. Oyun kazanana bir ödül vaat etmektedir. Bunun sembolik, maddi veya tamamen soyut bir değeri vardır. Ödül, altın bir kupa, mücevher, çeyrek bir florin gibi...92

Her müsabaka, yalnızca bir maddi kazanç için değil, aynı zamanda bir manevi değere ilişkin ve onun yardımı sayesinde de yapılır. Güç veya beceri, bilgi, ustalık, şan ve şöhret, iyi kalplilik veya mutluluk gibi değerler açısından da mücadele edilmektedir ancak bu olgular suistimale açık bir şsekilde tezahür etmektedir. Zira oyunda, hileye ve aldatmacaya da başvurulmaktadır. Bizim kavrayışımıza göre, hile ve aldatmacaya başvurulması, müsabakanın oyunsal karakterini bozar ve ortadan kaldırır. Çünkü oyunun özü, kurallara uyulmasıdır. ${ }^{93}$

Müsabaka kavramının karşımıza çıkma biçimi de ilerleyen, değişen ve gelişen dönemlerde özellikle top oyunlarının gelişimi itibariyle, karşılıklı gerçekleştirilen oyun biçimini almış ve gelişimini iyiden iyiye göstermiştir.

\footnotetext{
90 Huizinga, a.g.e., S: 74

${ }^{91}$ Huizinga, a.g.e., S: 75

92 Huizinga, a.g.e., S: 76

93 Huizinga, a.g.e., S: 77
} 


\subsection{MODER KÜLTÜRDE OYUNSAL ÖĞE}

Genç kuşaklar tarafından çok "eski zaman" a ait sayılan olgular, daha yaşlılar için hala "bizim zamanımız" kavramının içinde yer almaktadır. Bunun da sebebi, daha yaşlının bu zamana ilişkin kişisel bir anıya sahip olması değil de, kültürünün hala o döneme ait olmasıdır. Genel kurallar bütünü olarak, tarihsel dönem olgusuna sahip olan akıl, farklı bir bakış açısının gördüğü şimdiki zamandan daha geçmiş bir zaman dilimine kendi "modern" veya "çağın gerekliliğine ayak uyduran" kavramlarıyla bütünleşecektir. ${ }^{94}$

İçinde yaşamakta olduğumuz kültürün, hangi oyun türleri altında dağıtıldığı konusunda tarihsel süreç içinde çeşitli veriler karşımıza çıkmaktadır. Bu kültüre maruz kalan insanlar oyunsal zihniyete belirli ölçülerde maruz kalmıştırlar. İlk bakışta, toplumsal hayatın içindeki oyunsal türlerin farklı biçimi karşımıza çıkmış gibi görünse de yıllar içerisinde oyun kavramı spora indirgenmiş gibidir. ${ }^{95}$

\subsubsection{Bir Oyunsal Öğe Olarak Spor Kavramı ve Turnuva}

Spor kavramı, bireylerin "hareket” etme gereksinimini karşılaması, eğlence, oyun, neşelenme, keyifli vakit geçirme, hobi olarak, sosyalleşme, toplumda yer elde etme ve daha birçok nedenden dolayı tercih edilen faaliyetlerin bütünüdür. Spor, sözlük anlamı olarak incelendiğinde Latince Disportare ve Desport biçiminde "dağıtmak, birbirinden ayırmak" anlamına gelen sözcüklerden oluşmuştur. 17.yüzyıldan sonra ilk hecesi değişerek "SPORT" biçimine dönüştüğü araştırmacılar tarafından öne sürülmektedir. ${ }^{96}$

Spor, toplumsal işlev olarak anlamını sürekli genişletmeye ve giderek daha da geniş kitleleri etkisi altına almaya devam etmektedir. Çok eski dönemlerden beri, beceri, güç ve dayanıklılık müsabakaları her uygarlıkta ya ibadetle ilişkili olarak ya da sadece gençlik oyunları ve törensel eğlenceler olarak önemli bir yere sahip olmuşlardır. Ortaçağ toplumunda da yalnızca turnuvaya özel bir durum dikkat çekmektedir. Turnuva, fazlasıyla seyirlik ve aristokratik edasıyla, yalnızca spor olarak nitelenemez. Aynı zaman da tiyatro işlevi de

\footnotetext{
${ }^{94}$ Huizinga, a.g.e., S: 244

${ }^{95}$ Huizinga, a.g.e., S: 245

${ }^{96} \mathrm{http}: / /$ ds.anadolu.edu.tr/eKitap/SYT101U.pdf, (10.04.2015)
} 
görmektedir. Yalnızca, sınırlı sayıdaki seçkinler grubunun katılımı söz konusudur, bu durum da tarihsel kültürel süreçte dikkat çekici bir öğedir. ${ }^{97}$

Sportif müsabaka biçimleri, yüzyıllardan beri sabit kalmıştır. Bazı müsabaka biçimlerinde güç denemesi veya kimin daha hızlı olduğu ön plana çıkmaktadır. Koşu veya paten yarışı bunlara örnek olarak verilebilir. Bu tarz müsabakalar, düzenlenmiş oyun biçimine sınırlı olarak sahip gibi görünse de bunları oyun olarak adlandırmakta bir yanlışlık görülemez. Zaten, bir kurallar bütünüyle birlikte, kendiliğinden düzenli oyunlar halinde gelişen biçimler de vardır. Bunun en güzel örneği de, şüphesiz ki top oyunlarıdır. Bu bağlamda, eğlenceden, kulüp ve müsabakaya geçiş sorununa gelmiş oluyoruz. Bu kulüp ve müsabakaya geçiş süreci, belli bir grubun başka bir gruba karşı oynadığı bir oyundur. ${ }^{98}$

Esasında müsabaka ve örgütlenme olgusu dünya kadar eskidir. Bir köy başka bir başka köyle boy ölçüşmekte, bir okul başka bir okulla oynamakta, bir mahalle bir başkasıyla çekişmektedir. Daimi takımların birlikte antrenman yapmaları, özellikle top oyunları vesilesiyle ortaya çıkmıştır ve çağdaş spor olgusu da bu alandan beslenmiştir. Bu sürecin oluşumuna hiç kuşkusuz katkıda bulunan ve bir sonraki bölümde ayrıntılı bir biçimde bahsedileceği üzere, İngiliz halkının kendine özgü doğasının meydana getirdiği bir oyun olması inkar edilemez olsa da, bu oyunun XIX. yüzyılda İngiltere'de doğmuş olması da az veya çok açıklanabilir niteliktedir. İngiliz toplumunun temel özellikleri de hiç kuşkusuz bu oluşuma katkıda bulunmuştur. ${ }^{99}$

Şimdilerde yaşanan, oyunun sistemleştirilmesi, kurallaştırılması ve sürekli artan disiplini, oyunsal içeriğe ilişkin bazı durumları uzun dönemde yok etme noktasına getirecektir. $\mathrm{Bu}$ olgu, profesyonellerle amatörler arasındaki bağın kopuşunda açığa çıkmaktadır. ${ }^{100}$

Huizinga' ya göre; profesyonellerin tavrı artık bir oyun tavrı değildir, kendine özgülüğünü ve tasasızlığını artık kaybetmektedir. Spor, modern toplumda oyunsal alandan yavaş yavaş kopmuştur. Spor, bugünkü dünyada, asıl kültürün evriminin dışında bir yere sahiptir; bu kültür sporu içermez. Eski uygarlıklarda, müsabakalar kutsal bayramların içinde

\footnotetext{
${ }^{97}$ Huizinga, a.g.e., S: 245

${ }^{98}$ Huizinga, a.g.e., S: 245

${ }^{99}$ Huizinga, a.g.e., S: 246

100 Huizinga, a.g.e., S: 247
} 
yer alırken modern dönemde sporda, ibadetle olan bağlar tamamen kopmuştur ve toplumun organik yapısıyla bir bağlantısı kalmamıştır. Spor aslında, oyunsal içeriğin en iyi bölümlerini kaybetmiş ve daha ciddi bir hale bürünmüştür. ${ }^{101}$

Özellikle; artan nüfus, teknik, reklam gibi unsurların gelişimi ve kitleleri etkisi altına alması çeşitli propaganda yöntemleriyle her yerde rekabeti teşvik etmekte ve içgüdünün tatminini mümkün kılmaktadır. Bu bağlamda ortaya çıkan modern ticari ilişkiler ve istatistik sayesinde de artık sporun endüstriyel bir zemine oturtulması mümkün kılınmıştır.

Kültürel ve tarihsel değişim çerçevesinde oyun kavramının bu şekilde değişime uğradığını belirtebiliriz. İlerleyen başlıklarda tarihsel değişimler ve modern dönem hakkında daha ayrıntılı bilgiler verilecektir. ${ }^{102}$

101 Huizinga, a.g.e., S: 249

102 Huizinga, a.g.e., S: 249 


\section{BÖLÜM:POPÜLER BİR KÜLTÜR ÖRNEĞİ OLARAK FUTBOL OYUNU}

Futbol oyununa gelmeden önce oyunun kültürel unsurları, türleri ve oyun kavramına farklı yaklaşımlar spor ve müsabaka gibi ifadelerden bahsedilmiştir çünkü tarihsel gelişim sürecinde futbolun her şeyden evvel bir oyun olarak ortaya çıktığı bilinmesi gerekmektedir Bu bağlamda futboldan önce oyun kavramı hakkında ayrı bir başlık altında eleştirel incelemeler yapılmıştır. Bu ifadelerden sonra öncelikle dikkat çekilmesi gereken nokta; top oyunlarının nasıl ve hangi toplumlarda ortaya çıtı̆ğ, bunun beraberinde futbol oyununun ne amaçla gerçekleştirildiği, kurallarının ne olduğu, oyuncular, oyun mekanı v.b futbolu oyun yapan argümanlar ve öğeler ele alınması ve bağlamsal bir açıdan anlatım yapılması gerekmektedir

\subsection{FUTBOLUN TARİHÇESI}

Sıradan bir ayaktopu oyunundan, adeta bir güç imgesine, milli benliğe, uygar bir dine, halkları peşinden sürükleyen bir olgudan profesyonelliğe taşınan, oldukça geniş ve hareketli bir maziye sahip olan futbolun; tarihi gelişimini ifade etmek sadece kronolojik bir teknik çerçevede ele almakla değil, onu üreten insan yaşamında kapladığı alanla da açıklamak gerekmektedir. Futbol tüm dünyayı etkisi altına almış, kendini kabul ettirdiği her toplumda yeni bir tarih yazmış ve bu toplumlar tarafından ilk defa kendi ülkesinde doğmuşçasına benimsenmiş ve öznelleşmiş kitlesel bir olgudur. ${ }^{103}$

Futbolun nasıl incelenmesi gerektiğine dair yöntemsel ve biçimsel öğeleri "Futbolun İncelenmesi” adlı makalesinde derleyen daha önce popüler kültür bölümünde hakkında çokça adından söz edildiği İrfan Erdoğan bu sporun tarihte ortaya çıkış nedenini ve ihtiyacını şu cümlelerle ifade etmektedir: "Futbol dahil herhangi bir insan faaliyetinin tarihinde, öncelikli olan, neyin hangi tarihte çıktığını bulmak değildir; önemli olan, hangi insan ihtiyacından kaynaklandığı, kimin ihtiyacına yanıt verdiği, amacının ve ortaya çıkarılmak istenen sonuçlarının ne olduğudur. Futbol, bir yerlerde birilerinin günlük yaşamlarını sürdürmeleri sırasında ortaya çıkan ihtiyaçlarını karşılamak için çıkmıştır. Bu ihtiyaçlar, bir grubun kendini gerçekleştirmesiyle ilgili olabileceği gibi gruplar ve geniş toplumsal yapılar arasındaki

\footnotetext{
103 Gülşah Pilpil Yöney, Kitlelerin Afyonu Futbolun Latin Amerika Edebiyatındaki Yankıları Yayınlanmamış Yüksek Lisans Tezi, Ankara Üniversitesi Sosyal Bilimler Enstitüsü Batı Diller Ve Edebiyatları (İspanyol Dili Ve Edebiyatı) Anabilim Dalı, 2012, s.1
} 
ilişkisel bir ihtiyacı da olabilir. Bu ihtiyaç bir başarıyı kutlamayla ilgili olabileceği gibi, bir ilişkiye başlangıç veya sonuçlandırma, bir egemenliği perçinleme, bir yönetimsel yapıyı yeniden üretme, doğaüstü güçlerle ilişki kurma ve yürütme ile ilgili bir ihtiyaç olabilir. Futbol gibi bir oyuna ihtiyaç olarak rekabet, savaş, mücadele, yarış, grup veya sınıf farklılığı yaratıcılık ve deneyim, futbol etkinliğgi yoluyla beceri geliştirmeyle başka faaliyetlerde başarılı olma, sınıfsal farklılığı ve ilişkileri yeniden üretme, ruhsal gücün kendini ve gücünü yeniden ortaya çıkarması, eğlence ve futbol adı altında 'sirk ve ekmek', 'böl, birbirine düşür ve yönet' politikalarını gerçekleştirme, ticari çıkar sağlama gibi birçok neden verilebilir." Erdoğan'ın da makalesinde değinmiş olduğu gibi sınırlı sayıdaki tarihsel kanıtlar böylesine bir değerlendirmenin tam olarak gerçekleştirilmesini mümkün hale getirememektedir. Futbol oynandığı her çağda ve toplumda halkları etkileyen önemli bir insan pratiği olmuş ancak çok fazla kayıt altına alınamamışıtı. ${ }^{104}$

Tarihsel süreç çerçevesinde futbolun ortaya çıkışı ve yayılmasını daha önce yapılan araştırmalara göre, incelemek, değişim ve gelişim süreci içinde yaşadığı farklılıkları görmek mümkündür.

\subsubsection{Top Oyunları}

Top oyunları, en eski dönemlerden itibaren dünyanın hemen her köşesine yayılmıştır. Amerika'nın keşfi öncesi Orta Amerika' dan Çin' e firavunların Mısır' ından Eskimolara kadar... Burada dikkat çeken nokta bilinen bu top oyunları arasında tarihsel bir bağ yoktur, her biri diğerinden bağımsız bir biçimde gelişmiştir. İnsanlar, bu oyunlar aracılığıyla aynı anda birden fazla ihtiyacını gidermiştir. Bu top oyunlarının çoğunu,bir önceki bölümde sıkça adından bahsettiğimiz kültür tarihçisi Huizinga' nın bir ifadesiyle açıklayabiliriz; "Oyun bir şey için mücadele ve bir şeyin temsilidir." 105

Top oyunlarının ortaya çıkışı, sadece oyun olsun diye oynanan bağımsız birer etkinlik olarak değil, dini bir işlevi yerine getiren ve insan toplumuna hizmet eden oyunlar olarak tezahür etmiştir. Bunların oyalanma ya da vakit geçirmeyle bir ilgisinin olmaması dikkat çekici bir öğedir. ${ }^{106}$

\footnotetext{
104 İrfan Erdoğan, “Futbolun İncelenmesi”, Iletişim Kuram ve Araştırma Dergisi, Gazi Üniversitesi, Sayı 26,, 2008, s. 10.

105 Theo Stemmler, Futbolun Kısa Tarihi, Dost Yayınları, Ankara, 2000, S:10

106 Theo Stemmler, Futbolun Kısa Tarihi, S:11
} 


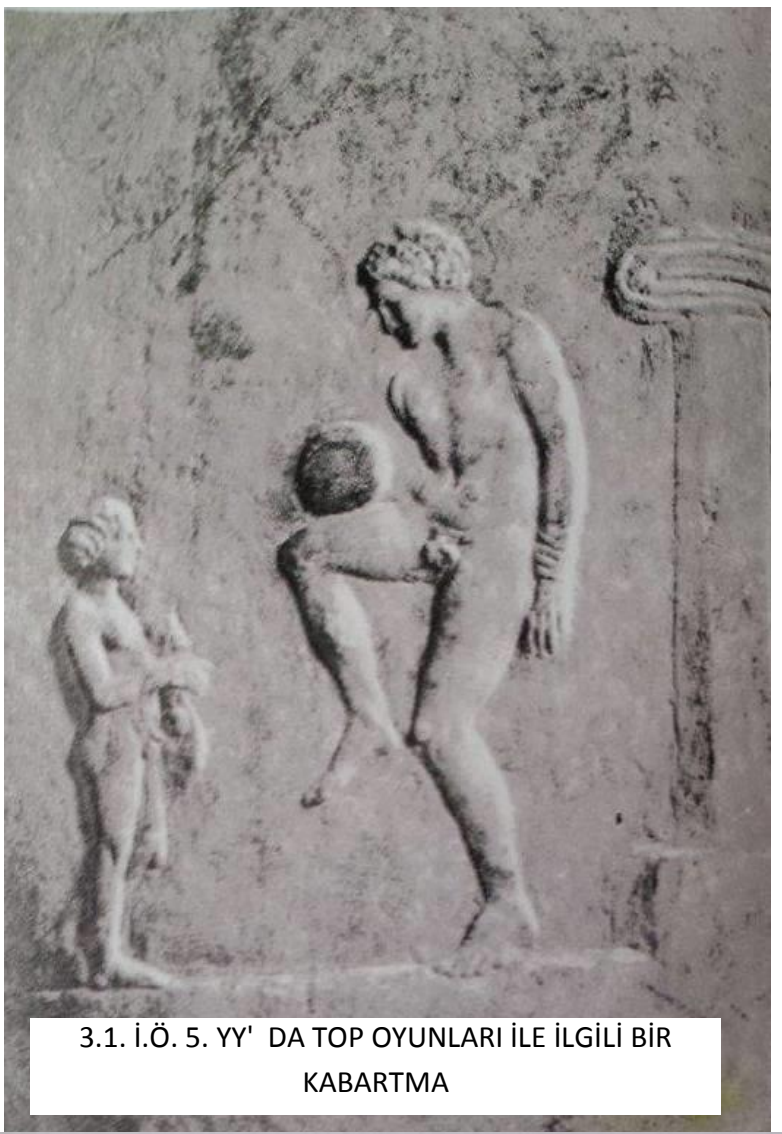

1. Top oynayan Azteklet. Christoph Weiditz'in çizimi, 1528.

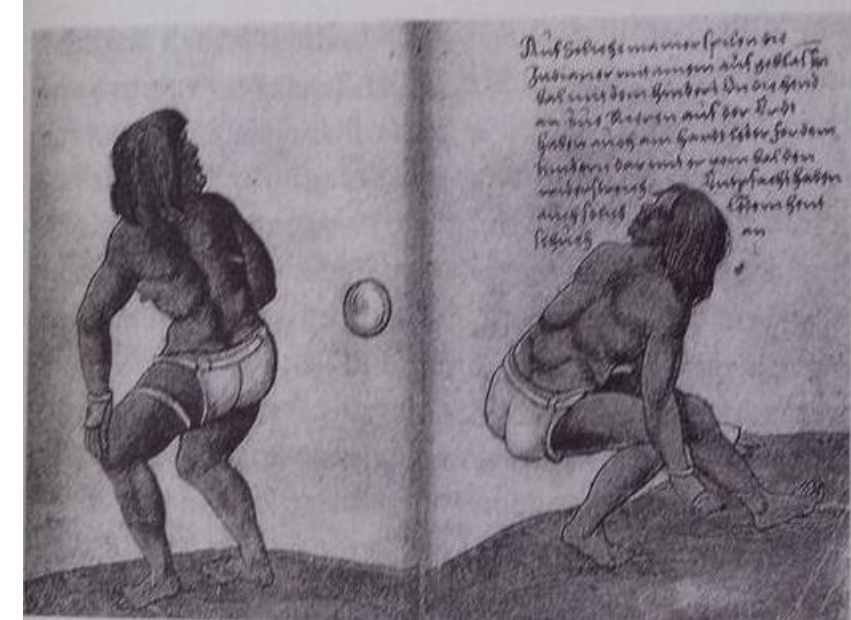

3.2. TOP OYNAYAN AZTEKLER
Eski Çin ve Japonya'da oynandıkları bilinen oyunlar tartışmasız birer futbol oyunu iken, eski Amerika oyunlarında daha ziyade farklı bir tür-top oyunu olduğundan bahsedilmiştir, bu nedenle bu top oyunun üzerine fazla durulması gerekmemektedir. Amerika'nın keşfedildiği dönem öncesine dayanan top oyunları hakkında çok fazla şey bilinmemektedir. ${ }^{107}$

Bu konu ile ilgili olarak Theo Stemmler önemli araştırmalara yapıp birtakım tarihsel bilgiler ortaya çıkarmıştır. Stemmler'ın araştırmaları doğrultusunda;Top oyunlarının ilk yıllarında edilen bilgilere göre; oyuncular topu uylukları, ayak bilekleri ya da elleriyle rakip sahaya atmaya, hatta mümkünse yan duvarlarda en azından son Aztek oyun alanlarının yan duvarlarında bulunan taş halkaların içinden geçirmeye çalıştıkları belirtilmiştir. Eski Amerika'ya özgü bu top oyunların dinsel nitelik taşıdığı söylenmektedir. Aztek diyarında keşfedilen yüzden fazla oyun sahası tapınakların birer parçasıdır. $\mathrm{Bu}$ oyunlar aracılığıyla güneşin ay ve yıldızlar üzerindeki zaferi, dolayısıyla bitki evreninin devamlılı̆̆ sağlanmaya çalışıldığı vurgulanmaktadır. Oyun sahası yeryüzünü, orta çizgi gece ile gündüz arasındaki sınırı, top güneşi ya da ayı, topun havada süzülüşü yıldızların geceleyin gökyüzündeki hareketini, topun halkalar içinden geçmesi ise yıldızların ufukta kaybolması gibi olayları simgelediği ifade edilmiştir. ${ }^{108}$ 


\subsubsection{Cinliler ayaktopu (futbolu) icat ediyor}

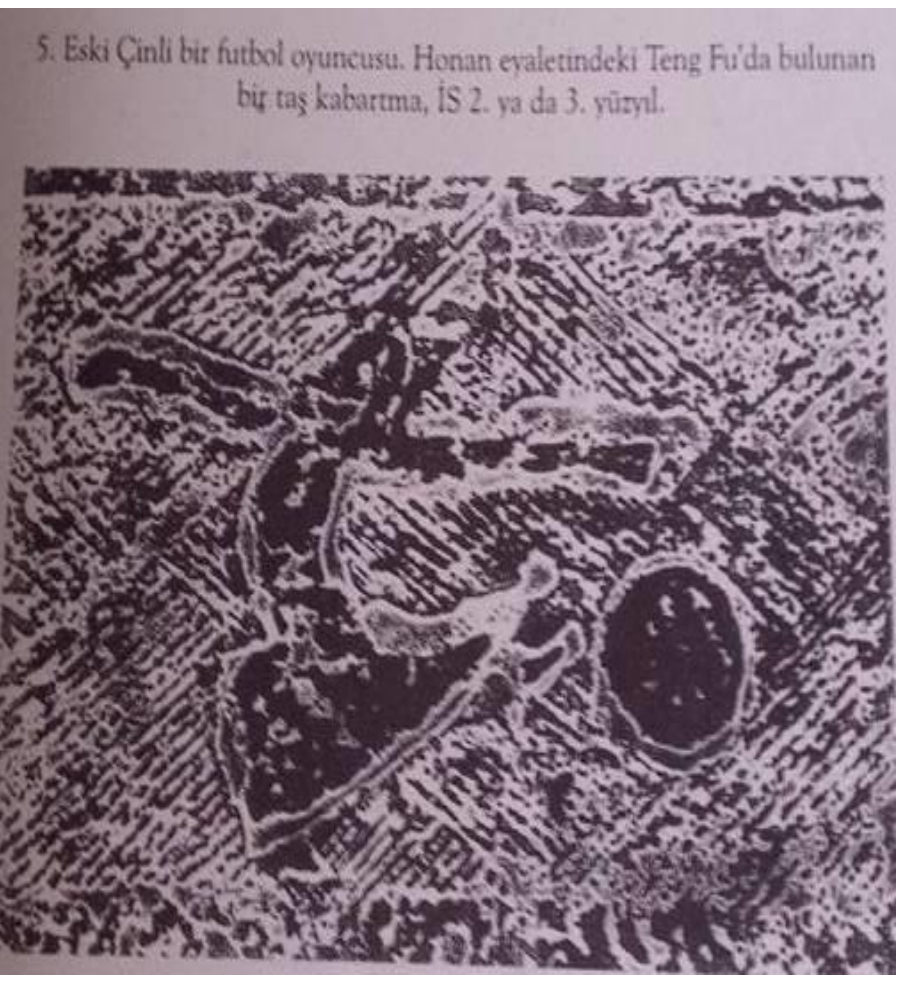

3.3. ÇINLI BIR FUTBOL OYUNCUSU I.Ö. 2-3 Y.Y.

Eduardo Galeano da futbolun kökeni hakkında, hemen hemen öbür dalların tümünde olduğu gibi öncülüğünün Çinliler tarafından yapıldığını araştırmış ve belirtmiştir.. Beş bin yıl önce Çinli hokkabazlar topu ayaklarıyla dans ettirmişlerdir ve daha sonra ilk oyunlar da yine Çin'de düzenlendiği bilinmektedir. Sahanın ortasında bir çit bulunmakta ve iki taraftaki oyuncular ellerini kullanmaksızın topun yere değmesini engellemektedirler. $\mathrm{Bu}$ gelenek, hanedandan hanedana aktarılarak sürdürülmüştür. Milattan önce yapılmış bazı anıtlardaki kabartmalarda ve milattan sonra yapılmış bazı rölyeflerde görüldüğü üzere Ming Hanedanı' na mensup Çinliler bugün günümüzde kullanılan futbol toplarına benzeyen toplarla bu oyunu oynadıkları görülmüştür. ${ }^{109}$

Maya, Aztek ve diğer Orta Amerika kavimlerinin Amerika'nın keşfinden önceki döneme ait top oyunlarıyla bilinen futbol oyunu arasında çok az sayıda benzerlikler olmasına karşın, daha önce belirtildiği üzere, eski Çinlilerin ts'u kü adlı oyunu günümüz futboluna şaşırtıcı derecede benzemektedir. Gerçekten de futbolu eski Çinliler icat etmiştir. Belki de futbolu, bazı efsanelerde iddia edildiği gibi, milattan önce üçüncü bin yılda, ama her halükarda, bu oyunun Çin kökenli olduğundan bihaber Avrupalıların futbolu yüksek ortaçağda keşfetmelerinden iki veya üç bin yıl önce icat ettiği görülmektedir. Çin kaynaklarına göre, futbol İ.Ö. 2697 civarında, efsanevi "beş imparator" dan biri olan Huangti zamanında oynanmaya başlanmıştır. ${ }^{110}$ Yine Çin kaynaklarına göre, ts'u (ayakla oynamak) kü (topu) anlamına gelmektedir. Yaklaşık onar kişiden oluşan iki takım dört köşeli bir oyun

\footnotetext{
${ }^{109}$ Eduardo Galeano, Gölgede ve Güneşte Futbol, Çev. Ertuğrul Önalp ve M. Necati Kutlu, Can Yayınları, İstanbul, 2011, S:54 110 Stemmler, a.g.e., S: 13
} 
sahasında başlangıçta içi tüy dolu bir topu bambu direklerinin yapılmış ve fileyle örülmüş olan yaklaşık beş metre yüksekliğindeki bir kaleye sokmaya çalıştıkları söylenmektedir. ${ }^{111}$

Kısa zamanda popüler hale gelen ve sevilen bu oyun sadece askerlerin oynadığı bir oyun olmaktan çıkmış, rahipler, generaller ve imparatorlar da bu oyunun bağımlısı olmuşlardır. Eski Çin futbolunu şaşırtıcı derecede modern kılan bir diğer özellik de şudur: Galip takım hediye yağmuruna tutulurken, mağlup takım azar işitmekte, hatta dayak yemektedir. Çinli filozof Konfüsyüs'ün (İ.Ö. 551-479) günümüzde bile geçerliliğini koruyan şu sözüne de dikkat çekmek gerekir: "Galibin burnu büyümemeli, mağlubun cesareti kırılmamalıdır" ancak günümüz futboluyla Ts"u kü birbirinize çok benzese de birbirleri arasında farklar olduğunu tarihsel kaynaklar açıklamıştır ve bu konu hakkında ilerleyen bölümlerde bilgiler aktarılacaktır. ${ }^{112}$

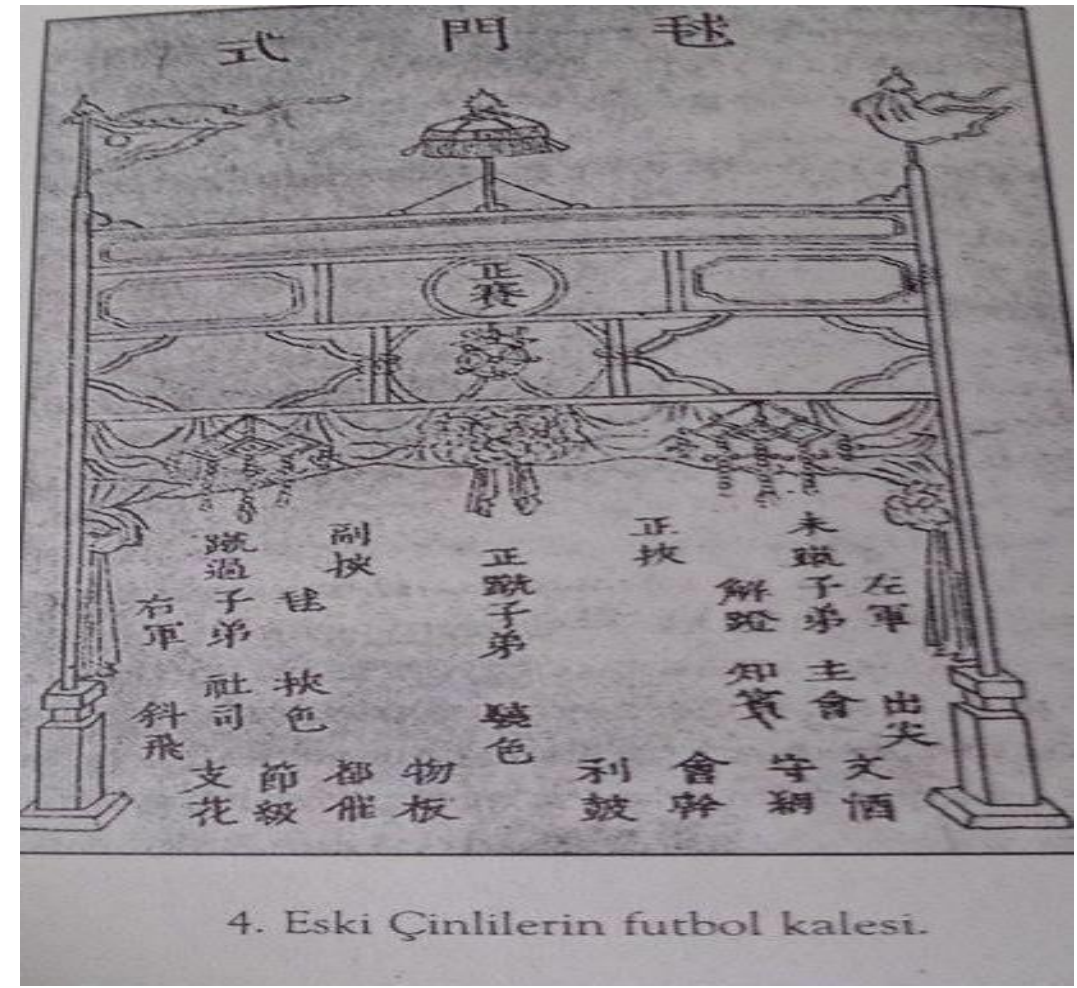

3.4. ÇINLLILERDE FUTBOL KALESI

${ }^{111}$ Stemmler, a.g.e., S: 14

112 Stemmler, a.g.e., S: 15 


\subsubsection{Diğer Uygarlıklarda Ayaktopu (Futbol)}

Eski zamanlarda Misırlıların ve Japonların topu tekmeleyerek oynadıkları bilinmektedir. Milattan beş yüzyıl önceye ait bir antik Yunan mezarının mermerinde bir adam topu diziyle vururken görülmektedir. Antiphanes' in komedya eserlerinde bunu ortaya koyan parçalar vardır: Uzun top, kısa pas ileriye atılan toplar gibi. Söylenene göre İmparator Julius Caesar her iki ayağını da ustalıkla kullanmaktadır. Neron ise yalnızca birini kullanabilmektedir. Kesin olarak bilinen, Romalıların futbola oldukça benzeyen bir oyunu oynadıklarıdır. $^{113}$

Yüzyıllar sonra 1314' te Kral II.Edward bu gürültülü ayaktakımı olarak ifade oyununu, Tanrı'nın izin vermediği birçok kötülüğe neden olan, büyük topların peşinde koşularak yapılan mücadele olarak niteleyen bir kraliyet fermanına mührünü vurmuştur. $\mathrm{Bu}$ dönemde oyun artık, futbol olarak adlandırılmakta ve ardında birçok kurban bırakmaktadır. Bir köy halkı öbür köy halkına karşı, topu, tekmeleyerek, yumruklayarak hedefe doğru sürüklemektedir. $O$ dönemlerde top yerine, değirmen taşı kullanıldı̆̆ı da görülür. Karşılaşmalar günler boyu sürmekte, birçok cana mal olarak geniş alanlara yayıldığı ifade edilmektedir. Krallar bu kanlı mücadeleleri yasaklamıştır. 1349'da III.Edward futbolu "işe yaramaz ve aptalca" oyunlara dahil etmiştir. 1410 'da IV.Henry 1547 'de VI.Henry tarafından imzalanan futbol aleyhinde fermanlar da vardır. O dönemde futbolun ne kadar çok yasaklanırsa o kadar çok oynandığı görülmüştür. $\mathrm{Bu}$ da yasaklamanın kışkırtıcı yönünü doğrulamaktan başka bir işe yaramamıştır.1592'de Shakespeare, Yanlışlıklar Komedyası'nda bir karakterin şikayetini belirtirken futbolu kullandığı görülmüştür:

Yuvarlak bir şey miyim ki,

Beni böyle ayaktopu gibi tekmeleyip duruyorsunuz?

Siz tekmeyle beni yollayacaksınız,

O bir tekmeyle beni geri postalayacak,

Ĕger böyle hizmet vereceksem beni meşinle kaplatın bari.

${ }^{113}$ Eduardo Galeano, Gölgede ve Güneşte Futbol, S:52 
Birkaç yıl sonra Kral Lear de, Kent Kontu, karşısındakine "Sen ! Aşağılık futbol oyuncu !" diye hakaret etmiştir. ${ }^{114}$

Milattan önce 1500 yıl önce kauçuk top, Meksika ve Orta Amerika'nın birçok yerinde futbolun ne zamandan beri oynandı̆̆ı bilinmemektedir. Bolivya'nın Amazon bölgesi yerlilerine göre de iki sopanın arasına ellerini kullanmadan sokmak için bu yuvarlak lastik topun peşinde koşturma işinin kökenleri çok eskiye dayandığı ifade edilmektedir. XVIII. yüzyılda Cizvit tarikatına mensup bir İspanyol rahip Parana yükseltisinde yaşayan Guarinlilerin eski bir geleneğinden söz eder: "Bu insanlar topu bizler gibi elle atmıyorlar, topa çıplak ayaklarının üst kısmıyla vuruyorlar."115

\subsubsection{Orta Çăğa Futbol}

Alfred Wahl, Ortaçağ ve modern Avrupa'da top oyunlarının halka özgü ve kaba bir özelliğe sahip olduğunu vurgulamıştır. Yazılı kurallar olmaksızın, geleneğin kurallarına göre bu oyun oynanmaktadır. Bu model kendi içinde, sayısız değişkene sahiptir. ${ }^{116}$

İngiliz futboluna geçtiğimiz zaman, 15.yüzyılın sonuna ait bir yazı dikkat çekmektedir. Son derece dindar bir zat olan Kral IV. Henry'ye (1421-1471) atfedilen bir mucizeden bahsedilir. Countonlu William Barttram maç esnasında tekme yemiş ve uzun süre dayanılmaz acılar çekmiştir. Fakat rüyasında VI. Henry'yi görmesiyle iyileşmesi bir olmuştur. Bu mucize şöyle devam eder:

Eğlenmek için oynanılan bu oyuna bazlları "futbol" diyor. Bu taşra oyununda genç erkekler büyük bir topu hareket ettiriyor, fakat topu elleriyle değil, ayaklarlyla havaya atarak değil, yerde sürüp yuvarlayarak... Oyun sahasının sınırları işaretlenmişti. Oyun başlayabilirdi artık. Kıran kırana mücadele ettikleri, topu dört bir sırada, kahramanımız izdihamın tam ortasına dald ve topu iskalayan vücudunun tam ortasina tekme attı... ${ }^{117}$

Bu örnek bize dönemin İngiltere'sinden futbol adına bir kesit sunmaktadır.

\footnotetext{
${ }^{114}$ Eduardo Galeano, Gölgede ve Güneşte Futbol, S:52

115 Galeano, a.g.e., S: 54

${ }^{116}$ Alfred Wahl, Ayaktopu Futbolun Öyküsü, Genel Kültür Dizisi, Yapı Kredi Yayınları,1998, S:12

117 Stemmler, a.g.e., S:29
} 


\subsubsection{Ingiltere ve İskoçya}

Rönesans döneminde genel olarak oyun, spor ve beden eğitimi üzerine sarf edilen sözler özellikle de futbol için geçerlidir. Bu diyarlarda futbola toplumun hemen her kesimi kucak açmıştır. Bu nedenle 1633 tarihli İngiliz tiyatro eserinde yer alan şu söz: "Football is all sport nowadays" (Günümüzde spor, futbol demektir). Futbolun dönemdeki yerini anlamamız için yeterli olacaktır.İngiltere'de egemenlik kurmaya başlayan futbol, coğrafi konumu ve özellikle yakın bölgelerde hızlı bir şekilde yayılması itibariyle kuşkusuz İskoçya'da da etkili olmuştur. $^{118}$

Avrupa ortaçağı 15. yüzyılın son demlerini yaşar. Ortaçağı en geç 16. yüzyılda Rönesans izler. Gerçekten de, antik mirasın adeta "yeniden doğuşu" anlamını taşıyan ifadeyi kapsamaktadır. Rönesans, yalnızca Yunan ve Latin dilleri, edebiyatı ve kültürünü değil, aynı zamanda kısmen de olsa insanı her şeyin ölçütü kabul eden antik çağa özgü yaşam duygusunu yeniden keşfetmek demektir. Rönesans, futbol açısından ortaya çıktığı dönem ve coğrafi konum itibariyle de önemli bir yere sahiptir. ${ }^{119}$

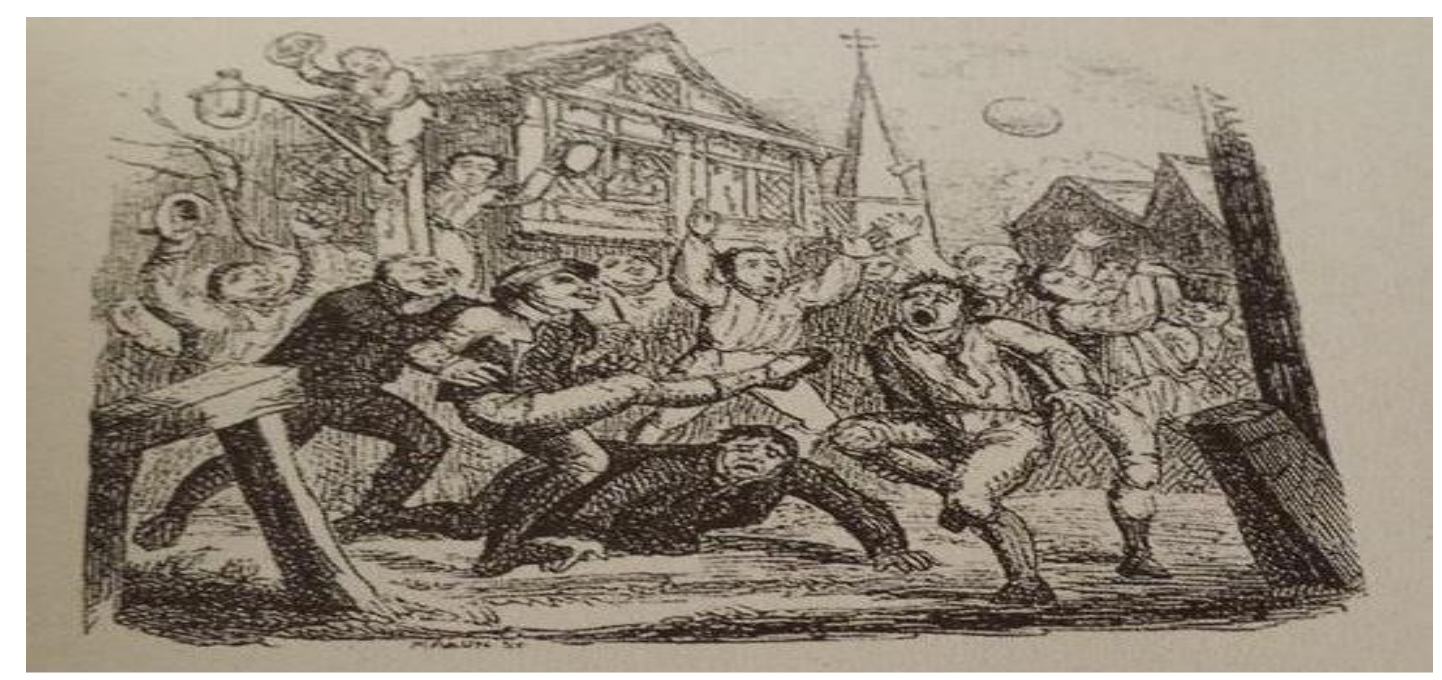

3.5. ORTAÇAĞ INGILTERESI' NDEN BIR FUTBOL KARESI

118 Stemmler, a.g.e., S: 39

119 Stemmler, a.g.e., S: 41 


\subsubsection{Bir Fransiz, Oyunu: La Soule}

19. yüzyıla kadar Fransa'nın Bretagne ve Picardie bölgelerinde yaygın olarak oynanan bu halk oyununun geçmişi, kırsal ve endüstri öncesi toplumun geleneklerine dayanmaktadır. Oynanış tarzına bakıldığı zaman, nasıl ortaya çıktığı belli olmayan, dinsel ve kiliseye bağlı olduğu anlaşılmaktadır. "La soule" iki komşu köyün gençlerini ya da aynı cemaatin bekarlarıyla yeni evlilerini karşı karşıya getirmektedir. Oyunun kesin kuralları yoktur. Esnek, yazılı kurallara dayanmayan ve yalnızca geleneğin meşru kıldığı bu uygulamalar son derece yavaş bir gelişim göstermiştir. Oyuncular, tüm fiziksel güçlerini kullanarak soule'ün üstüne çullanır ve topla birlikte ilerlemek amacıyla elleri ve ayaklarıyla dikkat etmeksizin birbirlerine girişirler. Oyuncular farklı görevlere göre sınıflandırılmaz; yalnızca güç ve hız hesaba katılır.Akı1 almaz mücadeleleri amansız koşular izler. Oyun taraflardan birinin topu önceden kararlaştırılmış alana getirmesiyle sona erer. 16. ve 17 yüzyılda futbola bir övgü futbolun ne derece etkin olduğunu katınlar niteliktedir. Bu övgü de şudur: "Futbol, insan vücudundaki tüm kasları kuvvetlendirir. Sıvı fazlasını aşağıya doğru sevk ederken, kafanın dinç olmasını sağlar... Futbol hazım için de iyidir ve mesane ili böbreklerdeki taşların ve kumların düşmesini sağlar. Baldırları en az atçılık kadar geliştirir... ${ }^{120}$

\subsubsection{Italyan Calcio'su}

İtalya'da futbol ise, sıradan halk yerine sadece soyluların oynadığı bir futbol versiyonudur. 15. yüzyılın sonlarına doğru oynanmaya başlanmıştır. Kuzey Fransa ve İngiltere'de yüksek ortaçağdan beri oynanan ilkel halk futbolu arasında farklar olsa da bu dönemdeki futboldaki gelişimin temeli İtalya gibi bir ülkede soyluların oynadığı bir oyun olma özelliği göstermesinden kaynaklanmaktadır. ${ }^{121}$

İtalyan futbolu , şu anda da olduğu gibi calcio olarak adlandırılmıştır. Leonardo da Vincinin de koyu bir futbol taraftarı olduğu bilinir. Machiavelli ise bizzat futbol oyuncusudur. 27 kişilik ekipler üç sıraya dağılmış şekilde oyuna katılmışlardır; ellerini ve ayaklarını topa vurmak ve rakiplerinin karnını deşmek için kullanmışlardır. ${ }^{122}$

\footnotetext{
120 Alfred Wahl, Ayaktopu Futbolun Öyküsü, S:12-13

${ }^{121}$ Stemmler, a.g.e., S:47

122 Eduardo Galeano, Gölgede ve Güneşte Futbol, S:54
} 
Modern kitle toplumunun temeli hatta ön koşulu İngiliz futbolunun asırlar boyu süren düzensizliği ve toplumsallığıdır. Futbol 16. ve 17. yüzyıllar boyunca her yerde günün konusudur ve şaşırtıcı biçimde yepyeni bağlamlarda ortaya çıkar: İngiltere'de ve İskoçya'da, İtalya'da ve Fransa'da görüldüğü üzere her yerde yaygındır.

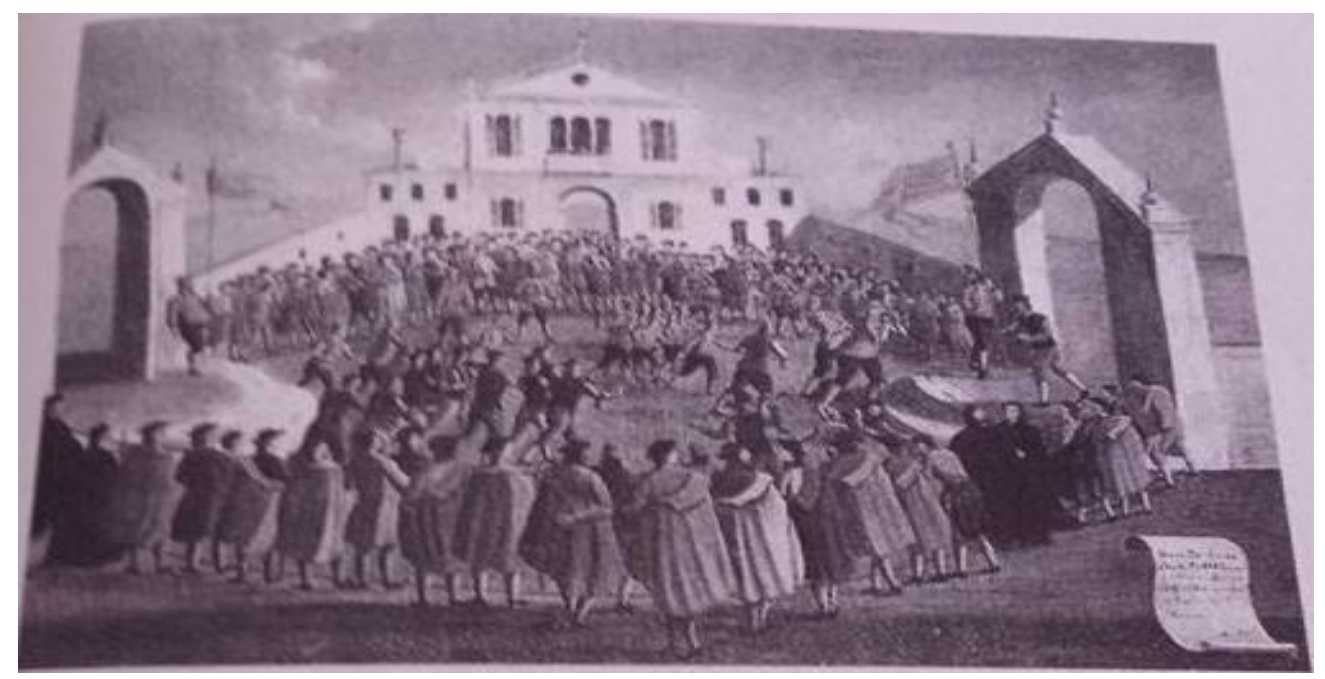

3.6. 18. YÜZYILDA VENEDIK' TE ITALYAN CALCIOSU

\subsubsection{Ayaktopu: evrensel bir geleneksel oyun}

Ortaçă̆ İngiltere'sinde de bu tür popüler top oyunlarına rastlanıyordu: Shakespeare'in Kral Leare'inde karakterlerden biri şöyle haykırır: "Seni beş para etmez ayaktopçusu." Top oyunlarının edebi eserlerde de kendine yer bulması da dikkat çekici bir unsurdur. ${ }^{123}$

Rönesans İtalya'sında Bolonya ve Floransa'da, topa ayakla müdahale edilen quico del calcio adlı bir oyun oynanıyordu. Paskalya ya da karnaval bitiminde oynanan calcio, kesin çizgilerle belirlenmiş ve küçültülmüş alanlar içinde oynanan bir oyundu. Sahanın iki uç çizgisi hedef nokta olarak belirlenmişti. Oyuncuların topu ellerinde taşımasına izin veriliyordu. Görev dağılımları ve kolektif oyunun ilk belirtileri üstünkörü de olsa ortaya çıkmaya başlamıştı: calcio modern futbolun ilk işaretlerini veriyordu. Esas itibariyle top oyununu etkin hale getiren topluluk, hemen hemen aynı dönemlerde İngiltere'de varlığını sürdüren public school'un (devlet okulu) kaymak tabakadan gelen öğrencileridir. Top oyunu, bu okullarda öğrenciler tarafından özerk biçimde düzenlenen bir eğlence haline gelmiştir. ${ }^{124}$

\footnotetext{
${ }^{123}$ Alfred Wahl, Ayaktopu Futbolun Öyküsü, S:13

124 Wahl, a.g.e., S: 13
} 
İlk zamanlarda, tam olarak 1830'a kadar, top oyunları kolejlerde kökensel özelliklerini korudular: dağınık, belli bir biçimi olmayan bir düzenleme, yazılı kuralları olmayan değişken ve gelişmeye açık bir uygulamaydı. Her kurum kendine özgü bir gelenek inşa ediyordu. Sahanın büyüklüğ̈nü, oyunun süresini ya da oyuncu sayısını belirleyen kurallar söz konusu değildi. Karşılaşmalarda görev dağılımının yapılmadığı ve atakların savruk olduğu görülüyordu. İçtenlik kadar güç de önemliydi. Sonuç olarak, cemaatin rolü bireyin ortaya çıkmamasıyla belirginleşiyordu. ${ }^{125}$

\subsubsection{Futbol Oyununun Sporlaştırılması}

1830 'dan itibaren, İngiltere'nin endüstriyelleşmesinin de etkisiyle,"public school' larda (devlet okulu), Futbol oyununun kesin bir dönüşümü beraberinde getiren bir değişim süreci başlar. Angaryalar azalır, öğrenciler arasında ilişki düzene girer; böylelikle kolejler barışa kavuşur. Bu yatışma sonucunda, yazılı ve belirgin kurallara dayanan, eskiye göre daha az şiddetli ve kişilik yapısını güçlendirmeye yönelik bir kendini denetleme mekanizmasını sağlayan bir oyunun yaratılması için gerekli ortam kurulur. Böylece modern futbolun doğmasına uygun bir zemin hazırlanmış olur. Özellikle öz denetime önem ağırlık verilir, kişisel roller önem kazanır ve çeviklik şiddetten daha önemli hale gelir. ${ }^{126}$

\subsubsection{Football Association'ın Kuruluşu (Futbol Birliği)}

Futbolun yaygınlaşması ve yayılmasının hızlı bir biçimde gerçekleşmesinden dolayı kurumsallaşma gereği duyulmuştur. Bu bağlamda 1863 yılında orjinal adı Futbol Association olan Futbol Birliği kurulmuştur. $\mathrm{Bu}$ kuruluşun amacı futbol oyununu belli kurallar çerçevesinde kurumsal bir yapıya dönüştürerek etki alanını genişletmektir. 1862 yılında kurulmuş FC Barnes kulübünün avukatı olan Ebenezer Morley Futbol Birliği kuruluşunun babası olarak kabul edilmektedir. ${ }^{127}$

Bu bağlamda, Futbol Birliği tam olarak kaptanların ve kulüp başkanlarının imzaları ile ve destekleri ile İngiltere' de 28 Ekim 1863 yılında bir pazartesi akşamı kurulmuştur.

\footnotetext{
125 Wahl, a.g.e., S:16

$126 \mathrm{Wahl}$, a.g.e., S:17

127 http://www.thefa.com/about-football-association/history, (23.04.2015)
} 


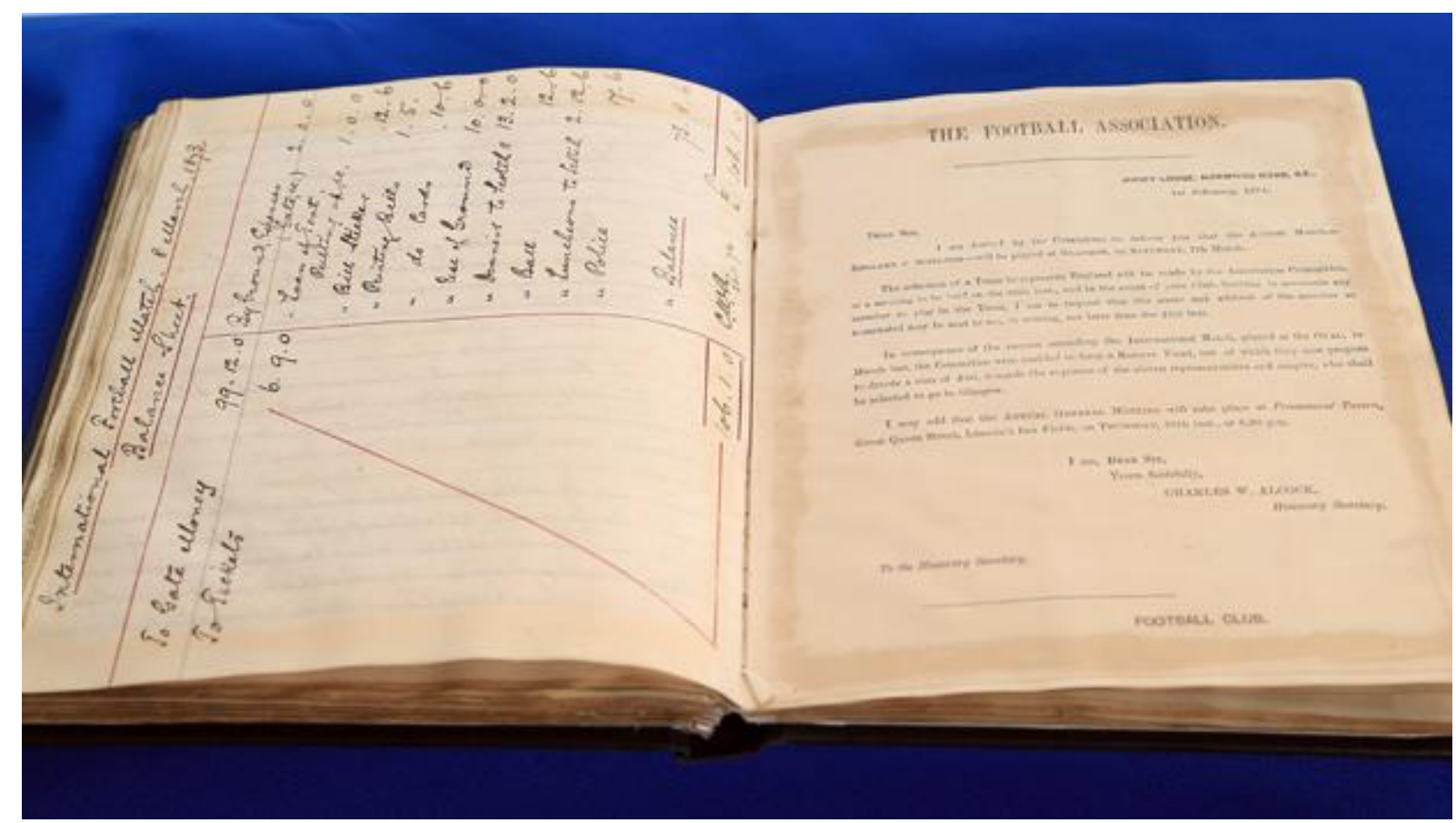

3.7. 1863 FUTBOL BiRLiĞi' NIN KURULUŞU

FA ile birlikte futbolun ülkenin tamamına yayılması gayesi gerçekleştirilmiştir. Futbolun yayılması 1860'ların sonunda başlar ve zaman zaman orta sınıfın yararına olan cumartesi öğle sonrası tatilinin düzenlenmesi sayesinde hem toplumsal hem de bölgesel planda gelişir. Esas olarak, oyunun yangınlaşması 1870'lerin başlarında İngiltere'nin Lancashire şehrinde başlar. Kısa süre içerisinde para, tazminat ya da transfer ücreti görünümünde işin içine girer. ${ }^{128}$

1905 'te FA' ya bağlı on bin kulüp ve 1910'da da FA' ya kayıtl1 300.000 lisanslı amatör oyuncu vardır. Oyun halk katmanlarına yayılır, seçkin tabakanın oyuncuları çoktan geri çekilmiştir. FA kulüp yönetimlerinin çoğunda olduğu gibi her zaman orta sınıf tarafından yönetilir. Bu durum, dönemin yönetimsel özelliği açısından önemli bir yere sahiptir.Futbol, tartışmasız en popüler gösteri halini almıştır. Kupa finalleri adı altında, çeşitli futbol müsabakalarının yer aldığı turnuva düzenlenir. İlk kupa finalini iki bin kişi izler. Bu sayı 1888 'de on yedi bine, 1893 'de kırk beş bine, 1901 'de yüz on bine ulaşır. Seyirci sayısındaki bu artıştan dolayı daha büyük stadyumların inşa edilmesi ihtiyacı doğmuştur. Futbol, otuz yıldan

128 http://www.thefa.com/about-football-association/history, (23.04.2015) 
kısa bir süre içinde popüler kültürün en canlı unsurlarından biri haline gelir. Özellikle işçiler, yüzlerce gazetenin yansıttığı sonuçlar üzerine günü gününe yorumlar yapmaya başlarlar. ${ }^{129}$

Bir başka kaynağa göre de 1871 y1lında federasyona üye kulüp sayıs1 50 iken, bu rakam 1888'de 1000 'e 1905 'te 10 bine ulaşmıştır. 1871 yılında "İngiltere Kupası" maçları geleneği başlatıldığında, seyirci sayısında muazzam bir artış görünmüştür. İlk yıllarda en az 4-5 bin seyirci gelirken bu rakam 1884 yılında 12 bine 1888'de 27 bine, beş y1l sonra 45 bine 1901' de ise tam 110 bine ulaşır. Bu seyirci kitlesi ağırlıklı olarak " oyun hakkında her şeyi bilen, ama oynayamayan" insanlardan oluşuyordu. Futbol daha o zamanlarda, seyircilerin ödediği paraya karşılık onlara bir şeyler sunması da gereken bir gösteri olma yolundadır. ${ }^{130}$

\begin{tabular}{|c|c|}
\hline 1848 & $\begin{array}{l}\text { Tüm futbol kurallarının "Cambridge Kuralları" adı altında birleştirilerek, tüm İngiltere'de aynı } \\
\text { standartta futbol oynanmasının sağlanması ve bu kurallara göre Cambridge'de öğrenciler arasında } \\
\text { ilk futbol maçının oynanması. }\end{array}$ \\
\hline 1857 & İngiltere'de ilk futbol kulübü Sheffield Club'ün kuruluşu. \\
\hline 1863 & $\begin{array}{l}\text { Futbolun İngiltere'de uyandırdığı büyük ilgi karşısında } 11 \text { kulüp temsilcisini; Londra'da, Great } \\
\text { Queen Street' teki Lincoln Hanı altındaki bir birahanede toplanıp, futbol dünyasının ilk } \\
\text { federasyonu olan İngiltere Futbol Federasyonu "Football Association (The FA)"u kurmaları (28 } \\
\text { Ekim 1863). Bu tarih, modern futbolun doğuş tarihi olarak kabul edilmektedir. }\end{array}$ \\
\hline 1879 & $\begin{array}{l}\text { Glasgow'dan Danven'e, para ve parlak iş teklifleriyle futbolcu getirtilerek futbolda profesyonellik } \\
\text { yolunda ilk adımın atılması. }\end{array}$ \\
\hline 1885 & Futbolda profesyonelliğin, İngiltere Futbol Federasyonu tarafindan resmen kabulü. \\
\hline 1889 & $\begin{array}{l}\text { Futbolun İngiltere adalarından taşıp Avrupa'ya yayılmaya başlaması karşısında Danimarka ve } \\
\text { Hollanda'da ilk futbol federasyonlarının kuruluşu ve } 1890 \text { yılında Futbol maçlarında tam } \\
\text { salâhiyetin hakemlere verilmesi. }\end{array}$ \\
\hline 1893 & Amerika kıtasında ilk futbol federasyonunun Arjantin'de kurulması. \\
\hline 1908 & $\begin{array}{l}\text { Londra Olimpiyat Oyunları ile futbolun ilk kez Olimpiyat Oyunları'nda yer alma ve İngiltere'nin } \\
\text { şampiyon oluşu. }\end{array}$ \\
\hline
\end{tabular}

Tablo 3.1. FUTBOLUN KURUMSALLAŞMASI

129 Wahl, a.g.e., S: 27

130 Stemmler, a.g.e., S:98-100 


\subsubsection{Futbolun Dünya' ya Yayılmast}

1870'li y1llardan itibaren, dünya üzerindeki birçok İngiliz vatandaş1, Football Association'1 Latin Amerika'ya ve hatta Asya ve Afrika'ya kadar yayar. İngilizler, daha sonra da yerli dernekler kurarlar, karşılaşmalar düzenlerler ve ulusal federasyonlar kurarlar. Bu dönemde oyun halk katmanlarına yayılır. Futbolun yayılmasını sağlayanlar, dünyadaki İngiliz ekonomik yayılımının aktörleridir. Gemiciler, 1874'te Botafogo'da, Brezilya plajlarında ya da on yıl sonra Marsilya ve Portekiz'de tutku ve merak dolu gözlerle futbol oynamaktadırlar. Oyun, denizcilik şirketi işçileri, 1872'de Havre'daki South Western Railway işçileri ya da 1890'a doğru, Porto ya da Bilbao limanlarındaki işçileri gibi yerleşik grupların ortasında daha kalıcı bir hale gelir. Futbol, Lizbon'da telgraf üreten işçiler ya da 1885 'e doğru Rio Tinto madenlerinde çalışan teknisyenler yoluyla tüm coğrafyaya yayılır. ${ }^{131}$

Dünya çapında kabul edilmeye başlanan futbol dili sayesinde, tarlalardan kovulmuş işçilerle Avrupa'dan kovulmuş işçiler birbirlerini gayet iyi anlamışlardır. Futbolun ortak dili, yoksul yerli halka, denizi aşarak gelmiş, Vigolu, Lizbonlu, Napolili, Beyrutlu ya da Basarabyalı; Amerika heveslisi duvar işçisi, hamal, fırını ve çöpçü emekçileri bir araya getirmiştir. Hoş bir yolculuk yapmıştı futbol; İngiltere'de üniversitelerde ve kolejlerde doğmuştur, Latin Amerika'da ise hayatında okula hiç adım atmamış insanların hayatını renklendirmiştir. ${ }^{132}$

İlerleyen dönemlerde de Orta, Batı ve Kuzey Avrupa'ya kadar da sınırlarını ilerleyerek genişletir. Çok kısa süre içerisinde, futbolun Güney Avrupa ve Latin Amerika'ya yayılması itibariyle de artık global bir oyun haline geldiğini belirtmek gerekmektedir.

\subsubsection{Uluslararası Futbol Federasyonu (FIFA)}

Uluslararası Futbol Federasyonu gerçek adıyla The Fédération Internationale de Football Association (FIFA), 1904'te iki Avrupalı tarafindan kurulur. Hollandalı Hirschmann ve ilk başkan olan Fransız Robert Guerin. FIFA her ülkeden bir tek federasyonu tanıma kararı alır, bu koşul birbirine bağlı federasyonların kendi ülkelerinde tekeli sağlamaları için bir fırsat sağlar; bundan böyle FIFA' ya bağlı olmadan yabancı kulüplerle karşılaşmak olanaksız hale

\footnotetext{
131 Wahl, a.g.e., S:29,30
}

132 Galeano, a.g.e., S:58 
gelir. 1921'den 1954'e kadar Jules Rimet tarafindan yönetilen FIFA, Birleşmiş Milletler Örgütü'ne benzer bir gelişim gösterir. Merkezi Zürih'te bulunan FIFA, 1984'te 52 milyon oyuncu ile 150 ulusal federasyonu denetlemektedir. ${ }^{133}$

Bir kararsızlık döneminden sonra FIFA, ulusların ağız birliğiyle yürürlüğe giren kurallarla düzene kavuşur ve Bohemya gibi bağımsız olmayan ulusların federasyonlarının üyeliğini geri çevirir. Robert Guerin, FIFA'nın himayesinde düzenlenecek olan uluslararası bir yarışma fikrini ortaya atar. Bu tasarı tam anlamıyla bağımsız hale gelmeden önce, bir süre Olimpiyatların çatısı altında kalır, FIFA bu organizasyon içindeki futbol turnuvalarının denetimini üstlenmiştir. Bu bağlamda ilk dünya kupası da 1930 yılında Uruguay' da gerçekleşir. ${ }^{134}$

$\mathrm{Bu}$ dönemden itibaren 2.dünya savaşı dönemi hariç dört yılda bir dünya kupası düzenlenmektedir. $\mathrm{Bu}$ düzenlemenin denetlemesi, organize edilmesi ve hangi ülkede yapılacağına karar verilmesi FIFA tarafından gerçekleştirilmektedir.

\subsubsection{Modern Futbol}

Evrensellik ve sınırlı değişimler üzerine kurulu olan futbol kuralları basittir; öncülerin oyunun ayırt edici özelliklerini korumak istedikleri doğasına uygundurlar. Ama söz konusu özellikler hedefe ulaşmayı da zorunlu kıldığından, teknik yenilikler ve taktik kadar hazırlanma süreci de pratiği değişime uğratır. Gerek oyunun kuralları gerekse de antrenman gibi taktiksel ve teknik özellikleri itibariyle daha sistemli bir değişime ihtiyaç doğmuştur bu bağlamda modern futbol olgusu ortaya çıkmaya başlamıştır. ${ }^{135}$

Modern futbolun doğuşu dediğimiz zaman aklımıza gelmesi gereken ilk akademik kurum kuşkusuz Cambridge Üniversitesi'dir. Cambridge, futbolun bir düzene oturtulmasında ve hayatta kalabilmesinde çok etkin bir rol üstlenmiştir. Bu bağlamda Cambridge' deki etkin kişiler aracılığıyla futbol kuralları belirlenmiş ve bu kurallar kısmen günümüzde bile halen geçerliliğini korumaktadır:

- Takımlar bir "takım kaptanı" nın liderliğinde oynanan on birer oyuncudan oluşur.

\footnotetext{
133 http://www.fifa.com/about-fifa/who-we-are/history/index.html , (24.04.2015)

${ }^{134} \mathrm{Wahl}$, a.g.e., S:60

135 Wahl, a.g.e., S:63
} 
- Hakem zorunludur.

- Oyun sahas 150 x 100 yarda (137.16 x 91.44 metre) boyutlarındadır.

- Oyun süresi 75 dakikadır; ilk yarıdan sonra (37.5 dakika sonra rakipler kale değiştirir. ${ }^{136}$

$\mathrm{Bu}$ belirlenen kurallar doğrultusunda modern futbol Londra'daki bir tavernada dünyaya gelmiştir. Orada Futbol Federasyonu'nun oyun kuralları karara bağlanır. Bu bağlamda diğer kurallar da şöyle sıralanmıştır: ${ }^{137}$

- Kalenin iki direği arasındaki "herhangi bir yükseklikten" geçen top, "goal" (gol) olarak değerlendirilir,

- Kaleciler hariç hiçbir oyuncu topa elle müdahale edemez ve topu eline alarak koşamaz,

- Çelme takmak, tekme atmak ve rakibini tutmak yasaktır ve bu ihlaller sonucunda rakip takıma serbest vuruş hakkı tanınır,

- Ayakkabının ucuna çivi takmak ya da tabanına demir pençe koymak yasaktır. ${ }^{138}$

\subsection{FUTBOL OYUN KURALLARI TARİHSEL GELISŞIMI}

Yüzyılın oyunu olarak kabul edilen futbol; kuralları, kültürü, ekonomisi, ulusal ve uluslararası unsurları, mücadelesi, zevki vb. itibariyle kitleleri peşinden sürüklemiştir. $\mathrm{Bu}$ bağlamda, futbolun bu derecede cazip ve etkin bir hale bürünmüş olması şüphesiz, oyun kurallarının şekillendirdiği değişimin bir sonucu olarak ortaya çıktığı görülmektedir.

Futbol, kurallara bağlanıp bir oyun olarak ortaya çıkmasından sonra gelişme gösterdiği açık ve nettir. İlk basit futbol kurallarının 1863 yılında İngiltere Futbol Federasyonu tarafından oluşturulduğunu ve aynı tarihte modern futbolun başladığını bir önceki başlıkta dile getirildiğini belirtmek gerekmektedir. Ancak oyun kuralları ile ilgili olan değişiklikler 19.yüzyılın ikinci yarısında şekillenmeye başlamıştır. Buna göre, kronolojik sıralama doğrultusunda kısa bir özetleme yapacak olursak; 1872 yılında oyunun en önemli aracı olan topun ölçüleri değiştirilmiş ve korner(köşe vuruşu) kuralı kabul edilmiştir. 1875 yılında,

\footnotetext{
136 Stemmler, a.g.e., S:89

137 Stemmler, a.g.e., S:91

138 Stemmler, a.g.e., S:93
} 
kalelerin devreler itibariyle değiştirilmesi kuralı konulmuştur. 1881'de hakem kuralları yazılı olarak yer almıştır. 1883 'te taç atışları el ile atılmaya başlanmıştır. 1884 yılına gelindiği zaman, karşılaşmalarda hakemlerin kayıtsız şartsız tek yetkili olmalarına karar verilmiştir.1891'de penaltı(ceza) vuruşu getirilmiş ve kale ağlarından bahsedilmiştir. 1896 yılında futbol oyun kuralları ilk kez yayınlanmıştır. 1930 yılında, 14 maddeden oluşan oyun kuralları 17'ye çıkarılmıştır. Futbol oyun kuralları kolay anlaşılabilir ve yorumlanabilir olmasından dolayı, toplumlarda ilgi odağı haline gelmiş ve yaşadığımız döneme damgasını vurmuştur. Futbolun popülerliğinin artması itibariyle oyun kurallarında günümüzde dahi değişiklikler oluştuğunu görmek mümkündür. ${ }^{139}$

\subsubsection{Futbol Oyun Kuralları}

Futbol kuralları, 1848 yılında İngiltere'deki Cambridge Üniversitesi'nde atıldığını ve rugby(hem ayak hem el ile oynanan bir oyun) ile futbol oyunundan ayrıldığını belirtmekte tekrar fayda vardır. Çünkü futbol bu tarihten önce kuralsız ve kaba bir şekilde oynanmaktaydı. Futbol oyun kurallarının yayınlanması 1896 yılında gerçekleşmiştir ve böylelikle tüm dünyada ortak bir uygulama sağlanabilmiştir. Oyunda istikrar ve etkinlik sağlanması ancak bu şekilde mümkün bir hale gelmiştir. ${ }^{140}$

Bu bilgiler doğrultusunda futbol oyun kuralları, IFAB adı verilen Uluslararası Futbol Birliği Kurulu ve FIFA (Uluslararası Futbol Federasyonları Birliği) tarafından belirlenmektedir. Futbol оуипи temel olarak, 11'er kişiden oluşan 2 takımın, 1'i orta, 2'si yardımcı 3 hakemin bazı kurallarla yönettiği, 90 dakika boyunca birbirlerinin kalesine gol atmaya çalışmasından ibarettir. Takımlar, sınırları belirli ölçülerle çizilmiş oyun alanı içerisinde, üç direkten oluşan, boyu 2.44 metre, eni ise 7.32 metre olan kalenin içine topu ayakla atmaya çalışırlar. En fazla gol atan takım maçı kazanır. Gol olmaması ya da eşit sayıda gol atılması halinde her iki takım da 1'er puan alır. Galibiyete 3 puan verilirken, mağlup takım puan alamaz. Bu spor, yüzyılı aşkın bir süredir, bu kurallarla oynanmaktadır. ${ }^{141}$

\footnotetext{
139 Lale Orta, Futbol Oyun Kurallarının Evrimi (1863-2008), Gazi Üniversitesi illetişim Fakültesi Kuram ve Araştırma Dergisi içinde, sayı 26 kış-bahar, 2008, S: 462

140 Lale Orta, Futbol Oyun Kurallarının Evrimi (1863-2008), Gazi Üniversitesi illetişim Fakültesi Kuram ve Araştırma Dergisi içinde, S: 464,472

141 http://www.futbolsahalari.com/futbol-oyun-kurallari.html, (02.05.2015)
} 


\subsubsection{Temel Futbol Kuralları}

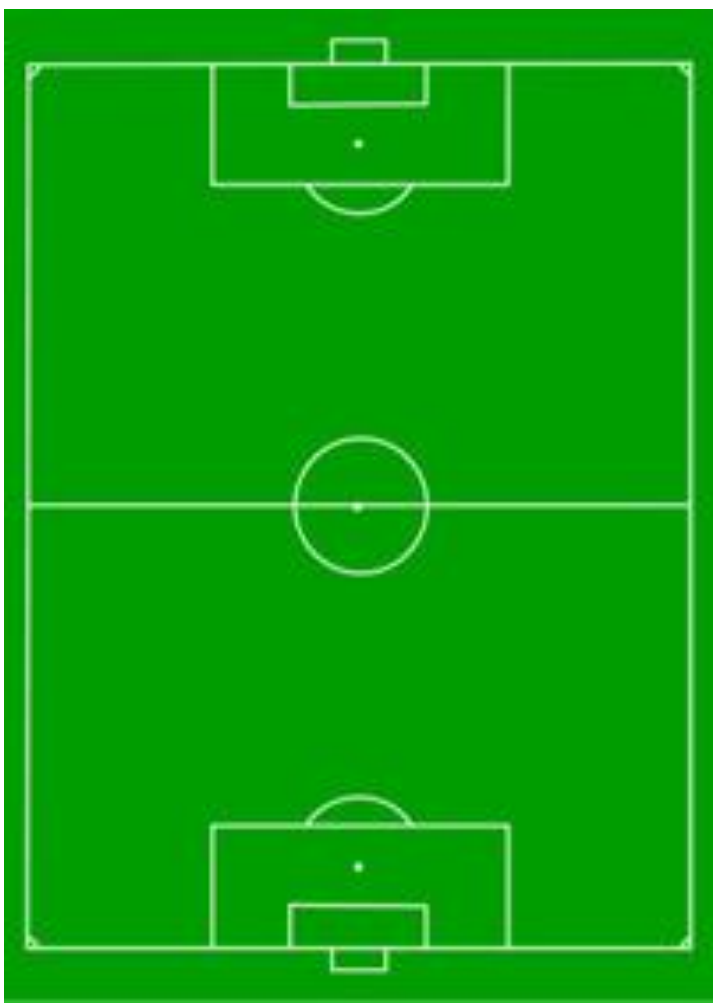

Ana hatlarıyla bu oyun, oyun alanı, oyuncular, hakemler ve toptan oluşmaktadır. Günümüze kadar geldikçe, ortaya çıkan sorunlar ve ihtiyaçlardan ötürü, futbol kuralları yenilenmiş ve oyunu hızlandırıp, güzelleştirip aynı zamanda daha seyredilebilir bir hale dönüştürülmüştür. İşte futbolun temel kaideleri :

* Oyun Alanı : Maçın oynandığı yer, dikdörtgen şeklindedir. Eni en az 45, en fazla 90 metredir. Boyu ise en az 90, en fazla 120 metre ile sinırlandırılır. Uluslararas1 müsabakalarda bu oranlar ende 64 - 75 metre, boyda ise 100 -110 metredir.

* Top : Yuvarlak biçimde olan bu oyun aracı, ortalama 410 - 450 gram ağırlığında olup çevresi de 68 - 70 santimetre arasında olmalıdır.

* Oyuncuların Sayısı : Her iki takımdan da oyun alanı içinde 11'er futbolcu bulunur. Maçın başlayabilmesi ya da devam edebilmesi için bir takımın saha içinde 7 kişiden az olmaması gerekir. Yedek kulübesinde en fazla 7 oyuncu bulundurulup, oyun süresi içinde bir takım en fazla 3 kez oyuncu değiştirebilir.

* Oyuncuların Giysileri : Her iki takım futbolcuları birbirinden farklı renklerde forma giymek zorundadır. Bir takımın tüm oyuncuları ise kaleci hariç, tek tip forma giymelidir. Genel anlamda giysiler, kısa kollu ya da uzun kollu forma, şort, uzun çorap, tekmelik ve futbol ayakkabısından oluşur.

* Hakem : Müsabakalar, oyun kurallarını uygulamada yetkili olan birisi tarafından yönetilir. Bu kişi hakemdir. Hakem, futbolculardan farklı renkte kıyafet giyer. Hakeme sahanın 2 karşı uzun çizgisinde bulunan ve bayraklarla oyuna müdahale eden 2 yardımcı hakem eşlik eder. Asıl ve tartışmasız kararı veren ise orta hakemdir. Hakem, kararlarını düdük çalarak duyurur.

* Maçın Süresi : Futbol, 45'şer dakikadan oluşan 2 devre halinde oynanan bir oyundur. Toplam 90 dakika süren maçın devre arası 15 dakikayı aşmaz. 
Ofsayt : Oyunun temel kurallarındandir. Bir oyuncu, rakip kaleye toptan ve rakibin sondan ikinci oyuncusundan daha yakın ise ofsayt pozisyonundadır. $\mathrm{Bu}$ pozisyon sırasında topa dokunursa, hakem ofsayt kararı vererek, karşı takım lehine düdük çalar.

* Fauller ve Fena Hareketler : Saha içinde oyunun kuralına göre oynanmasını sağlayan etkenlerin başında fauller gelir. Maçta faul yapan bir oyuncu, kuralları ihlal etmiş sayılacağından hakem tarafindan karşı takıma vuruş hakkı verilir. İşte 10 temel kusurlu hareket :

- Rakibe tekme atmak ya da tekme atmaya teşebbüs etmek

- Rakibe vurmak ya da vurmaya teşebbüs etmek

- Rakibi tutma

- Rakibe tükürmek

- Bilerek topa elle dokunmak

- Rakibi çelmelemek

- Rakibin üzerine sıçramak

- Rakibi itmek

- Rakibe şarj yapmak

- Rakibe ayakla kayarak müdahale etmek

Kusurlu hareketleri bir ya da birden fazla tekrarlayan oyuncu, faulün şiddetine göre sarı kart veya kırmızı kartla cezalandırılır. Kırmızı kart gören oyuncu, oyun alanından ihraç edilir ve bir sonraki müsabakada görev yapamaz.

Serbest Vuruşlar : Bu vuruşlar, hakem kararıyla belirlenip direkt ve en direkt olarak ikiye ayrılır. En direkt serbest vuruşta, topun oyuna girmesi için 2 farklı oyuncuya temas etmesi gerekir.

* Penaltı : Kusurlu hareketler, ceza sahası içinde olursa penaltı ile cezalandırılır. Kaleye 11 metre mesafede bulunan penaltı noktasından kaleye doğru yapılan vuruştur. Tek bir oyuncunun, kaleyi koruyan rakip kalecinin olduğu alana topa vurma avantajına sahip olmasidir. 
Taç Atışı : Oyuna yan çizgiden başlama yöntemidir. Oyuncu, çizginin gerisinden topu eliyle, başlarının üzerinden firlatarak oyuna dahil eder.

* Kale Vuruşu : Topun kalelerin yanından oyuna girmesidir. Rakip kaleye yapılan vuruşta, top kalenin dışından çizgiyi geçerse, tekrar kale vuruşuyla oyun başlar.

* Köşe Vuruşu : Rakip kaleye yapılan vuruşta, top rakip futbolcuya çarpıp, kalenin dışından oyun alanını terk ederse, vuruşu yapan oyuncunun takımı, topun çıktığı oyun alanı köşesinden köşe vuruşuyla oyunu başlatır. ${ }^{142}$

Oyun kuralları, temel olarak bu başlıklar altında toplanmaktadır. Oyun kurallarının değiştirilmesiyle etki alanını daha da genişleten futbol oyunu; Fair-Play, Pozitif oyun, Hücum futbolu, Defansif taktikler, Bariz gol şansı, Taktik faul, Hücum faul, gibi kavramların da ortaya çıkmasına zemin hazırlamıştır. ${ }^{143}$

142 http://www.futbolsahalari.com/futbol-oyun-kurallari.html, (02.05.2015)

143 Orta, a.g.e., S:476 


\begin{tabular}{|c|c|c|c|}
\hline 1863 & $\begin{array}{l}\text { Cambridge Üniversitesi tarafından futbol } \\
\text { oyunun rugby oyunundan ayrılması }\end{array}$ & 1891 & $\begin{array}{c}\text { Penaltı vuruşu getirilmiş ve ilk kez kale } \\
\text { ağlarından bahsedilmiştir }\end{array}$ \\
\hline 1866 & Ofsayt kuralının değiştirilmesi & 1896 & $\begin{array}{l}\text { Futbol oyun kuralları ilk kez } \\
\text { yayınlanmıştır }\end{array}$ \\
\hline 1870 & $\begin{array}{l}\text { Hava toplarının elle tutulması kuralı } \\
\text { kaldırılmıştır }\end{array}$ & 1905 & $\begin{array}{l}\text { Penaltı atışları sırasında kalecilerin kale } \\
\text { çizgisi üzerinde durması kuralı } \\
\text { eklenmiștir }\end{array}$ \\
\hline 1871 & $\begin{array}{l}\text { İlk kez kalecilerden bahsedilmiş ve topu } \\
\text { elle tutma hakkı sadece kalecilere } \\
\text { verilmiştir }\end{array}$ & 1912 & $\begin{array}{l}\text { Kalecilerin topu elle oynamaları sadece } \\
\text { ceza sahası alanıyla kısıtlanmıştır }\end{array}$ \\
\hline 1872 & $\begin{array}{l}\text { Topun ölçüleri belirlenmiş ve köşe vuruşu } \\
\text { kuralı kabul edilmiştir }\end{array}$ & 1913 & FIFA IFAB' in üyesi olmuştur \\
\hline 1875 & $\begin{array}{l}\text { Kalelerin devreler itibari ile değiştirilmesi } \\
\text { kuralı konmuştur }\end{array}$ & 1925 & $\begin{array}{l}\text { Ofsayt kuralında oyuncu şartı 2'ye } \\
\text { indirilmiştir }\end{array}$ \\
\hline 1878 & İlk kez düdük kullanılmıştır & 1929 & $\begin{array}{l}\text { Penaltı atışları sırasında kalecilerin kale } \\
\text { çizgisi üzerinde durma kuralı, kaleci } \\
\text { penaltı vuruşu yapılana kadar çizgi } \\
\text { üzerinde durmalıdır şeklinde } \\
\text { değiştirilmiştir }\end{array}$ \\
\hline 1881 & $\begin{array}{l}\text { Oyun kurallarında hakemden } \\
\text { bahsedilmiştir }\end{array}$ & 1938 & $\begin{array}{l}\text { Oyun kuralları önceki kuralları esas } \\
\text { alarak maddeler haline getirilmiş ve } \\
\text { daha kolay anlaşılabilmesi için yeniden } \\
\text { yazılmıştır }\end{array}$ \\
\hline 1883 & $\begin{array}{c}\text { Taç atışları el ile kullanılmaya } \\
\text { başlanılmıştır }\end{array}$ & 1970 & $\begin{array}{l}\text { İlk defa sarı ve kırmızı kartlar } 1970 \\
\text { Meksika Dünya Kupası' nda } \\
\text { kullanılmaya başlanmıştır }\end{array}$ \\
\hline 1884 & $\begin{array}{l}\text { Karşılaşmalarda hakemlerin kayıtsız } \\
\text { şartsız tek yetkili olmalarına karar } \\
\text { verilmiştir }\end{array}$ & $\ldots$ & $\begin{array}{l}\text { Oyun kuralları günümüzde hala } \\
\text { düzenlenip değişiklilere uğramaktadır }\end{array}$ \\
\hline
\end{tabular}

Tablo 3.2. FUTBOL OYUN KURALLARININ EVRIMI 


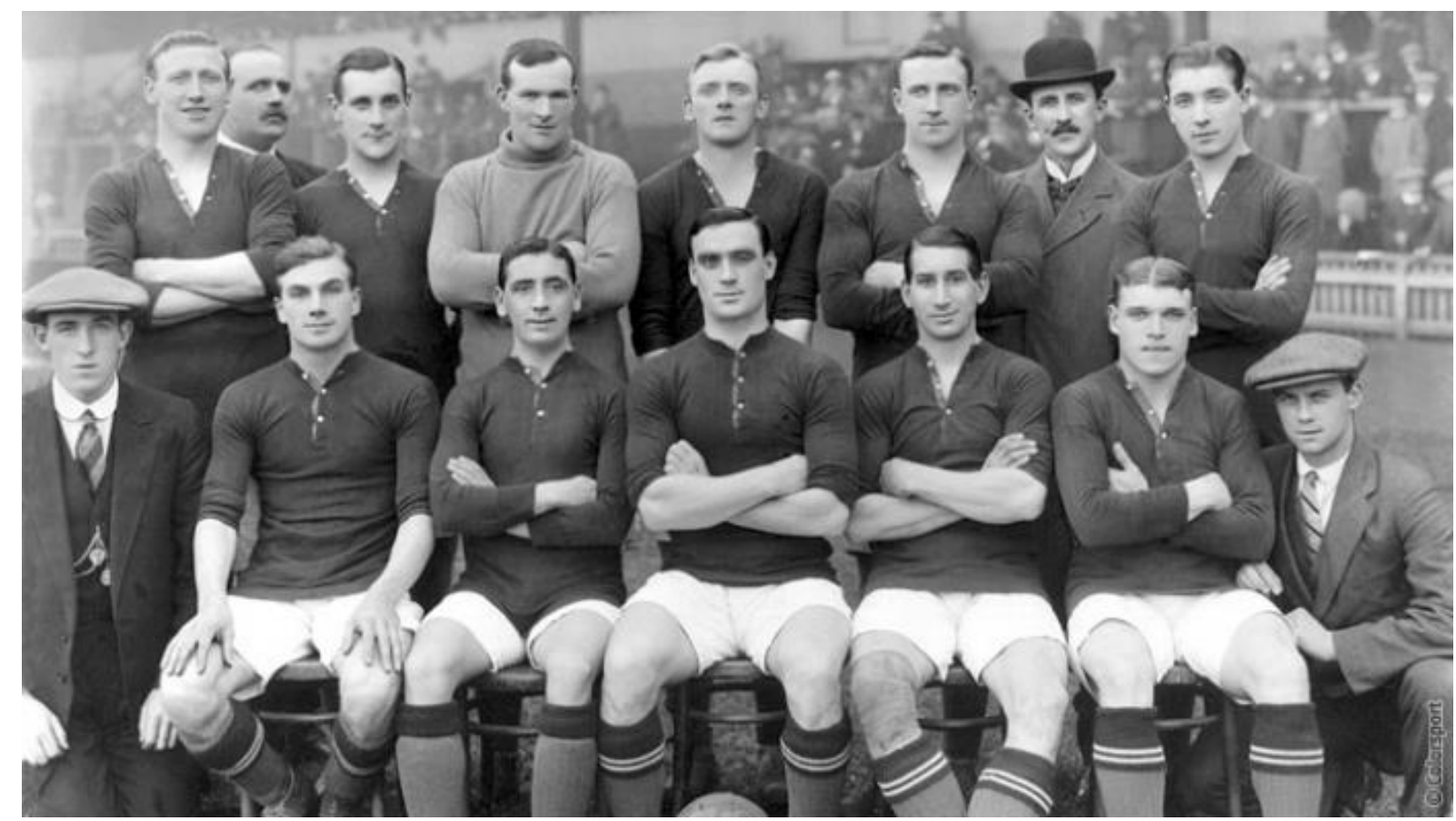

3.8. işÇi FUTBOLUNUN BIR SONUCU OLARAK KURULAN ARSENAL KULÜBÜ 1914-1915

\section{3. İŞÇI FUTBOLUNUN MODERN FUTBOLUN GELIŞ̧ìINE ETKİSi}

Günümüzde bir oyun ve bedensel aktivite dışında futbol, sosyal olgulara ilişkin bir anlamlandırma ve gösterge unsuru olarak birçok araştırmaya konu olmaktadır.Bu bağlamda futbolun tarihsel gelişim sürecinin öncelikli olarak bilinmesi gerektiğini vurgulamak gerekir. Futbolun tarihsel durumunu ve tam anlamıyla anlaşılmasını ancak işçi sınıfı ve gündelik hayat kültürünün bağlantısının incelenmesiyle mümkün olduğu, dünya genelinde modern futbolun ortaya çıkışında, kurumsallaşmasında ve yayılmasında, ortaya çıkan kuralların ve düzenlemelerin uygulanması bakımında da, Sanayi Devrimi ile gelişen işçi hareketlerinin etkisinin oldukça fazla olduğunu ve futbolun sınıfsal mücadelede etkin bir araç olarak geliştiği söylenmelidir.Bilindiği gibi tarihsel süreç içerisinde Sanayi Devrimi, devlet ve toplum yapıları yönünden değişimler meydana getirmiş ve toplumsal hayat düzeninden yeni yapılar ortaya çıkarmıştır.Bu bağlamda Sanayi Devrimi etkisi ile hızlanan sanayileşme ve kentleşme olgusu, işçi sınıfının ortaya çıkmasına sebep olmuştur. ${ }^{144}$ Bu süreçte ,modern anlamda futbolun da doğuşu ve gelişimi Sanayi Devrimi ile beraber gelen şehirleşmenin etkisi büyüktür. Buna göre de, modern futbol Sanayi Devrimi'nin 19.yy başının bir evladı olarak

\footnotetext{
${ }_{144}$ Mustafa Yaşar Şahin ve H.Mehmet Tunçkol, İş̧i Hareketlerinin Futbolun Tarihsel Gelişim Sürecine Etkisi, 220 TSA/YIL:14, S:1, NISAN 2010, s.219
} 
nitelendirilebilir. ${ }^{145}$ Modern futbolun işçi sınıfı içinde yayılması da 19.yüzyılın son çeyreğinde hızlanarak etkinliğini sürdürmüştür.Bu etkinliğin sürmesinin alt yapısında Sanayi Devrimi'nin bir sonucu olarak ortaya çıkmış olan fazla çalışma saatlerinin yaşam standartlarını ve işçilerin verimliliğini düşürdüğü gerekçesiyle birtakım düzenlemeler yapılması gereği doğmuştur Buna göre, 14 Avrupa ülkesinin katıldığı Berlin Konferansı'nda, çalışma saatleri ile ilgili "zaruri olan sanayiden gayri, sanayide çalışan bütün işçilere hafta tatili hakkı" tanınması kararı alınmıştır. ${ }^{146}$ Bu düzenleme ile birlikte işçi sınıfına, anlamlı bir şekilde geçirebilecekleri bir boş gün sunulmuştur. İşte tam bu aşamada asiller, centilmenler, kapalı bir kast halinde kriket ve tenis gibi oyunları oynamayı sürdürürken, proletarya (İşçi sınıfi) futbolu geliştirmeyi başlamıştır. Bu açıdan bakıldığında futbol, soyluların uzantısı olan kolej amatörlüğüne karşı demokratik bir devrim olarak görülebilir. ${ }^{147}$

İşçi sınıfına sunulan bu boş vakit uygulamasında, bahsedildiği üzere yoğun çalışma saatlerinden dolayı psikolojik ve fiziksel yorgunluğa düşen işçilerin bir nevi kendilerini yenileme ve hareket etme ihtiyaçlarının karşılanması hedeflenmiştir ancak şu unutulmamalıdır ki serbest zamanlarda futbol vb sosyal aktivitelerin ortaya çıkması da endüstrileşmenin bir sonucudur.

Boş vakitlerin değerlendirilme çabası, özellikle modern futbol ortaya çıktıktan sonra artan çok nüfuslu işçi mahallerinde futbol aracılığıyla birlik ve beraberlik oluşturmaları daha kolay olmuştur. Dolayısıyla bu kalabalık nüfusa sahip olan bu işçi mahalleleri birçok futbol kulübünün doğmasına zemin hazırlamıştır.Buna bağlı olarak da oyun sahalarında artış olmuştur. $^{148}$

$\mathrm{Bu}$ kulüpler, işçi örgütlenmeleri yoluyla sporun ve futbolun yayılmasını hızlandırmış ve bu sayede kurumsallaşma ve gelişmeye katkı sağlamışlardır.Bu bağlamda, ilk kez Almanya'da 1890 yılında "İşçi Spor Kulüpleri kurulmaya başlanmıştır. Bunu daha sonra Finlandiya, İsveç gibi ülkeler izlemiştir. İlk adımları 1908'de atılan ancak resmi kuruluş tarihi

\footnotetext{
145 Metin Kurt, Spor, Toplum ve Ötesi, Özgür Üniversite Forumu, sayı;25, s.131-140, 2004)' den akt: Mustafa Yaşar Şahin ve H.Mehmet Tunçkol, İşçi Hareketlerinin Futbolun Tarihsel Gelişim Sürecine Etkisi, s.222

${ }^{146}$ Cahit Talas, Sosyal Politika, Sevinç Matbaası, Ankara, 1967)' den akt: Şahin ve Tunçkol, İşçi Hareketlerinin Futbolun Tarihsel Gelişim Sürecine Etkisi, s.223

${ }^{147}$ Metin Kurt ve Veysel Atayman, Modern Sporun ilkelerinin Kökeni, "Arena Show" Modern Sporun Dünü ve Bugünü, Sorun Yayınları, İstanbul, 1997' den akt: Şahin ve Tunçkol,a.g.e, 223

${ }^{148}$ Roman Horak, Futbol Kültürü der.Roman Horak, Wolfgang Reiter, Tanıl Bora, illetişim Yayınları, 1993' den akt: Şahin ve Tunçkol,a.g.e., s.224
} 
24 Aralık 1934 olarak görünen "Iş̧̧̧i Jimnastik ve Spor Federasyonu (Federation Sportive et Gymnigue du Travail-FSGT)" kurulmuştur. FSGT, devlet tarafindan tanınan ve kamu yararına faaliyet gösteren bir kimliğe sahiptir. FSGT' nin mahalle örgütlenmelerinden kent örgütlerine kadar 4 bin alt kuruluşu 220 bin civarında üyesi bulunmaktadır. ${ }^{149}$

Bu kurumsallaşma etkisi ile birlikte halen günümüzde de varlığını sürdüren ve tarihsel süreç içerisinde işçi sınıfının ortaya çıkardığı kulüpler doğmuştur. Bu ekipler endüstrileşme sürecinin bir etkisi olarak ortaya çıkıp varlığını halen sürdürmektedirler. Bu ekipleri kısaca şöyle sıralayabiliriz. İngiliz kulüpleri olan Liverpool ve Southampton(Woolston Tersanesi), Sheffield(Bıçak Üreticileri), West Ham(Demir İşletmeleri), Manchester United(Dokuma),Arsenal(Kraliyet, silah ve cephane fabrikası).İspanya'da ise Atletico Madrid kulübü İspanyol işçiler tarafından kurulan bir kulüptür. Aynı şekilde Almanya' da FC Schalke 04 ve Borrusia Dortmund kulüpleri Ruhr adı verilen maden bölgesi işçilerinin oluşturduğu kulüplerdir. ${ }^{150}$

Görüldüğü üzere geçmişten günümüze varlığını hala sürdüren bu köklü kulüpler, işçi sınıfının modern futbola olan katkılarını gözler önüne sermektedir.

İşçi sınıfının, modern futbolun oluşumu içinde ne derece etkili olduğunu 1978 yılında Arjantin milli takımı ile Dünya kupası kazanan Cesar Luis Menotti' nin şu ifadelerine dikkat çekmek gerekmektedir. "Futbol sporu varoluşunu, emekçi halka borçludur. Futbolun mülksüz ve hakları elinden alınmış insanlar arasında doğmasının temel bir nedeni vardır. Ucuz ve neredeyse bedava oluşu. Bu oyunu yoksullar bulmuş ve ona karakterini vermiştirler... Söz söyleme ve özgürce konuşma hakkı elinden alınmış olan sıradan halk, o parasız eğlencede bir ifade biçimi, bir yaşam içeriği bulmuştur... Oyun sevinci içinde, yaratıcı yeteneğini geliştirmede kendilerini özgür hissetmişlerdir. Orada kendi yeteneklerinin farkına varmış, zekalarını kanıtlama olanağına kavuşmuş ve bu şekilde bir kimlik edinmişlerdir. Yani futbol sayesinde birisi olmuşlardır. ${ }^{151}$

\footnotetext{
149 Uğur Y., Halk Sporu Kurultayı, İnsanca Spor Dergisi(1), S: 2-3, 2012' den akt: Şahin ve Tunçkol,a.g.e., s.224 150 Kurthan Fişek, Sporun Anatomisi, YGS Yayınları, İstanbul, 2003' den akt: Şahin ve Tunçkol,a.g.e., s.225
}

151 Tanıl Bora, Karhanede Romantizm Futbol Yazıları, İletişim Yayınları, İstanbul, 2013, S:25 
Teknik direktör Menotti' nin bu derin ve anlamlı sözleri modern futbolun gelişimi ve evrimleşmesi açısından işçi sınıfının etkilerini bir kez daha bize kanıtlamaktadır ancak tarihsel değişim süreci içerisinde gerçekleşen futbolun, popülerliğinin artması ve futbolda profesyonelleşme sürecinin ortaya çıkmasıyla birlikte işçi futbolu varlığını pek sürdürememiştir ancak futbol işçi sınıfının kitle toplumuna dahil olma süreci açısından önemli bir yere sahip olmuştur. ${ }^{152}$ Modern futbolun mücadele olarak gösteri özelliğinin, dünyadaki süreç içerisinde az önce ifade edildiği üzere endüstriyel bir niteliğe evrilmesi, gerçek ifade ile ticari bir iş kolu haline gelmesi, işçi sınıfı futbolunun varlığını sürdürememe sebeplerinden en önemlisidir. ${ }^{153}$

\subsection{FUTBOLDA PROFESYONELLİĞIN ORTAYA ÇIKIŞI}

Futbolun gelişim süreci çerçevesinde, futbolun ahlaki olarak gelişmesinin en iyi yolunu profesyonelleşme olduğu düşünülmeye başlandı. Normal ekonomik dolaşımda olduğu gibi, patronlar yani yöneticiler ve ücretliler yani oyuncular söz konusu olursa durum daha belirgin olacağı düşünülüyordu. İlk olarak İngiliz, Alman ve İspanyol futbolu daha sonra finansal risklere bağlı endişelerden kurtarılarak Avusturya 1924'ten itibaren, Çekoslavakya ve Macaristan 1930'dan önce bu güç engeli aştılar, onları 1931 ve 1933'te Arjantin ve Brezilya izledi. Fransa 1932'de kabul etti. Gerçekte profesyonelleşme hiçbir şeyi aydınlamadı. Resmi makamların dayattığı ücretler bir kurmacadan başka bir şey değildi; ücretlerin arttırılması vaadi yaygındı ve statüler sürekli değişiyordu. Tazminat günümüzde bölgesel liglerde bile bir kural haline gelmiştir. ${ }^{154}$

\subsubsection{Oyuncu Pazarı ve Oyuncuların Gelirleri}

Profesyonel futbol ve hatta amatör futbolun üst kademeleri, oyun olma özelliklerini korumalarına rağmen, yeni bir ekonomik sektör haline geldiler. İngiltere'nin ardından profesyonellik yaygınlaştı ve bu durum fiyatlara ve oyuncu pazarına yön verdi. Önceleri sinırlı olan fiyatlar, 1950'den sonra gelirlerin yüksek olduğu zengin Avrupa kulüplerinde büyük artışlar gösterdi. Fransız yöneticilerde bunu örnek almayı denediler; Matra Racing'in 1986 'da Luis Fernandez adlı futbolcuya ayda 700,000 frank (106,715 euro) vermesinin nedeni

\footnotetext{
152 Pascal Boniface, Futbol ve Küreselleşme, Çev: İsmail Yerguz, Ntv Yayınları..5, İstanbul, 2007' den akt: Şahin ve Tunçkol,a.g.e.,s.234

153 Tuğrul Akşar, Endüsriyel Futbol, Literatür Yayınları, İstanbul, 2005' den akt: Şahin ve Tunçkol,a.g.e.

154 Wahl, a.g.e., S:88
} 
budur. En iyi oyuncular, futbolcuların Avrupa Birliği sınırları içinde serbest dolaşımını sağlayan "Bostman kararı"ndan (1995) sonra yurtdışna gitmeye başladılar. Böylece futbol pazarı daha yayılmaya ve gelişmeye başladı. ${ }^{155}$

Futbolda profesyonelliğin doğuşu ve oyuncu pazarı ve oyuncu gelirlerindeki düzenlemelerle birlikte artık futbolun iyice popüler bir gösteri aracı haline geldiği açık bir şekilde görülmüştür. Özellikle 1950' lerden sonra oyuncu transferlerinin ortaya çıkması, o günden günümüze kadar etkin bir şekilde devam eden ve oldukça fazla yatırımların yapıldığı bir endüstri halini almaya başlamıştır.

155 Wahl, a.g.e., S:105-106 


\section{BÖLÜM: FUTBOLUN POPÜLERLEŞME SÜRECİ VE KÜLTÜREL}

\section{İȘLEVI}

Dünyanın her yanındaki insan toplulukları üzerine muazzam etkiye sahip tek bir spor vardır, futbol. İnsan davranışlarını fazlasıyla etkileyen bu spor dalındaki karşılaşmalar bu etkiyi, farklı duygu yüklerini bir araya getirerek sağlar. Futbol, kimilerinin hayatının anlamını teşkil ederken, bazen de en korkunç suçları işlemek için bir neden haline gelir veya bir başkası için ise yalnızca rahatlatıcı özelliği olan mükemmel bir sığınaktır. Futbol, nispeten yeni ve modern bir spor dalıdır ancak ilk uygarlıklara kadar uzanan öğeleriyle yaygın kültür içine tamamıyla yerleşik durumdadır. Günümüz futbol stadyumları, oyuncuların etkileşim kurduğu yerler olan antik tiyatrolarla karşılaştırılabilir.

Bununla beraber; futbol oyunları, kitle iletişim araçları sayesinde futbolun vermek istediği mesajlar milyonlarca insana ulaşabiliyor. Açık olan şu ki futbol, kurallarla ve elde edilen sonuçlarla sınırlandırılan bir oyundan çok daha fazlasıdır. Futbol, kültürel bir ürün; onun anlamı ve önemi ise tamamen ekonomik ve politik ile belirleniyor denemez. Barlarda ya da restoranlarda insanlar canlı oyunlarda olduğu gibi, oyunun genel kültürü üzerinden belli bir kültürel kimliğin ifadesini tartışıyorlar. Diğer taraftan kitle iletişim araçları, reklamcılar, futbol aktivistleri, menajerleri ve oyuncuların kendileri de sorumluluk taşıyor. Eğitim, medya ya da din gibi futbol da gönderide bulunanların istedikleri içeriğin yayıldığı bir diğer kurum olarak dikkat çeker. ${ }^{156}$ (Sosyalizasyonun etkili bir aracı olarak futbol, Pierre Bourdieu'nun sembolik şiddet kavramına dikkat çektiği bir unsur olarak anlaşılabilir. Hiç şüphesiz ki, insanlar dahil oldukları kolektif kimliklere duydukları güçlü arzu nedeniyle de futbol takımlarını destekler. ${ }^{157}$

Genel anlamıyla futbol, en azından 90 dakikalık oyun boyunca farklı bütün gruplarla ve çeşitli toplumlarla her kesimin kaynaşması için bir firsat yaratır. Futbol müsabakasının ruhu, insan topluluklarının bütünleşmesi için imkan sunmaktadır. Şüphesiz, George Simmel' in dediği gibi hiçbir şey, bir düşmanın varlığı kadar bir zümreyi daha mahkum ve birbirine

\footnotetext{
156 Bartosz Weiss, Günümüzde Medeniyetler Çatışması Olarak Futbol: Rakip Tarafların İmgelerinin Yaratılışı, Cogito Dünya Gözüyle Futbol (İçinde), Yapı Kredi Yayınları, Sayı:63, 2010, S:112-114

157 Pierre Bourdiou ve Wacquant L.J.D, An Invitation to Reflexive Sociology, Chicago ve Londra University of Chicago Press, 1992'den akt: Bartosz Weiss, Günümüzde Medeniyetler Çatışması Olarak Futbol: Rakip Tarafların İmgelerinin Yaratılışı, Cogito Dünya Gözüyle Futbol, S:114
} 
bağlı kılamaz. Ayrıca takımların sembolleri ve çoğalan futbol mitleri, bütünleşme sürecine hız kazandırır ve taraftar kimliklerini kuvvetlendirir. Futbol, aslında dünyanın her yerindeki büyük izleyici kitlelerini heyecanlandıran olağanüstü bir şey bahşeder bizlere. Zaten futbolun icat edilişi amacı da bu değil midir ? ${ }^{158}$

\subsection{FUTBOLUN POPÜLERLEŞME SÜRECI}

19. yüzyılın ortalarında başlayan modern futbol serüveni, modernleşme ve sanayileşme süreçleri ile üretim ve organizasyon modellerinin paralelliği doğrultusunda gelişme göstermiştir. Adeta hayatın yoğunlaştırılmış bir hali gibi görünen bu oyunda, insanlar yaşamları içinde adını koyamadıklar pek çok şeyin yansımasını bulmaktadırlar. Biraz da bu sebepten ötürü futbol artık sadece futbol değildir, popüler kültürün en önemli unsurlarından birisidir. Bir oyun olmasının ötesinde futbol toplumsal yaşamın içerisinde var olan bir rol model işlevi görmektedir. Futbol, 19. yüzyılın ortalarından günümüze kadar olan süreçte popülerliğini ve etkinliğini her geçen gün arttıran küresel hale gelmiş bir olgudur. ${ }^{159}$

$\mathrm{Bu}$ olgunun popülerleşmesi futbolu oynayandan çok izleyenle ilişkilendirilerek açıklanabilir. Önceki başlıklarda futbolun tarihsel gelişiminde izleyenden çok oynayanların etkinliği görülmekteydi. Futbol küreselleştikten sonra ve bunun beraberinde kitleleri peşinden sürüklemesi itibari ile oynayandan izleyene doğru bir geçiş dönemine girmiştir. $\mathrm{Bu}$ da futbolunun popülerliğinin artmasının bir tezahürüdür.

Özgür Dirim Özkan' a göre de "Futbolun popülerliği" nden bahsederken, referansımız "oyun oynayan" dan çok "oyunu izleyendir." Yani "oyun" bir nesne olarak oyun alanından daha çok, oyun alanının dişında kültürel etkinliğini sürdürmesiyle, "spor"dan daha çok "kültürel etkinlik" olarak karşımıza çıkmaktadır.Elimizde pozitif veri olmamasına rağmen, ampirik gözlemlerimizden yola çıkarak, futbolun küresel olarak en popüler spor dalı olduğunu söyleyebiliriz. Futbolun popülerliğinin arkasında yatan en önemli etken, futbolun bir takım

\footnotetext{
158 Weiss, a.g.e., S:119

159 Ahmet Talimciler, Futbol Değil İş: Endüstriyel Futbol, İletişim Kuram ve Araştırma Dergisi İçinde, Sayı 26 Kış-Bahar, 2008 , S:90-91
} 
oyunu olmasıdır. Peki dünyadaki tek takım oyunu futbol mu? Elbette değil, ama futbol diğer takım oyunları arasında sıyrılan en popüler oyundur. ${ }^{160}$

\subsubsection{Futbolu Popüler Yapan Etkenler}

Futbolu popüler yapan birçok etken vardır. Farklı kitlelerin ve grupların, değişik amaçlara hizmet etmesi sonucu futbol, değişik kimliklere bürünmüştür. Bütün bunlar futbolu günümüzde önemli bir endüstri haline getirmiştir. Futbolun tüketime çok açık, heyecan veren yapısı, diğer spor dallarına göre daha ucuz, eğlenceli ve daha geniş kitlelerce benimsenmesi futbolun diğer spor dallarının önüne geçmesinde şüphesiz önemli bir rol oynamıştır. ${ }^{161}$

Futbola popülerlik kazandıran en önemli etkenleri şu şekilde sıralayabiliriz; medya, pazarlama ve reklâm, siyaset v.b... Futbolu bu denli popüler yapan en büyük etken medyadır. Medya düşünce ve kamuoyu oluşturur. Etki alanı insan zihinleridir. Dolayısıyla da eylemlere egemen olur. İnsanların davranışlarını, arzularını, inançlarını, yaşam biçimlerini yaptıkları seçimleri etkisi altına alır. İnsanın ve toplumun düşünce yapısı ne şekilde ve hangi yönde oluşturulursa o şekilde ve o yönde hissedecek, heyecanlanacak ve hareket edecektir. ${ }^{162}$

Medyaya futbolun çok geniş bir şekilde yer alması, futbolun kitlelerce çok çabuk kabullenmesini sağlamıştır. Futbol maçlarının televizyonlardan canlı olarak verilmesi bireyleri stadyumlara taşımakta, daha önce belirtildiği gibi futbolu evrensel bir olgu haline getirmesini daha da kolaylaştırmaktadır. Böylece çok farklı kültür ve statüdeki bireyler ortak amaçta buluşmaktadırlar.

Medyanın yayın organlarının çeşitliliği, futbolu seven farklı kültür ve statüdeki bireylere farklı biçimlerde ulaşmaktadır. Gazetelerin spor sayfaları, tamamen spor içeren gazete ve dergiler, spor kitapları, radyo ve televizyonda yayınlanan spor programları, spor ve özellikle futbola popülerlik kazandırmaktadır. Yayın medyası (televizyon, kablolu yayın ve radyo) bir bilgi, analiz ve eğlence kaynağı olarak dünyanın her yerinde insanlar tarafindan kullanılır. Medya günümüzde çağdaş yaşamın en büyük parçası olarak değerlendirilir. Sporu

160 Özgür Dirim Özkan, Futbolun Kültürü Spor mu, Oyun Mu Yoksa (hala) Afyon mu?, KÜLT: İstanbul Bilgi Üniversitesi, Kültürel Çalışmalar, Sayı 2., S: 2

${ }^{161}$ Selçuk Özdağ, Savaş Duman ve Bülent Fişekçioğlu, Popüler Kültür: Futbol mu Putbol mu?, Türkiye Kickboks Federasyonu Spor Bilimleri Dergisi, Sayı: 4, Sayı:1, Ocak, 2011, S:15

162 Ahmet Erimhan, Medya ve Değişim, Yeni Türkiye Dergisi Medya Özel Sayısı. 12, 1503-1507, 1996' den akt: Selçuk Özdağ, Savaş Duman ve Bülent Fişekçioğlu, Popüler Kültür: Futbol mu Putbol mu?, Türkiye Kickboks Federasyonu Spor Bilimleri Dergisi, Sayı: 4, Sayı:1, Ocak, 2011, S:15 
bunun dışında düşünmek mümkün değildir. Spor ve yayın arasındaki ilişki karşılıklıdır. Her biri diğerini etkiler ve birinin popülerliği ve ticari başarısı diğerini etkiler. Medya, oyun ve müsabaka başına tanıtım, yorum, spor olayının tanıtımında aracılık, heyecan, spor ve sporculara destek sağlar. ${ }^{163}$

Şüphesiz ki futbolun popülerliğinin artmasının temel niteliği medyadır. Çünkü medya üzerinde durduğumuz gibi kitlelere çok hızlı bir şekilde yayılan bir aracı görevi üstlenmektedir. Medya, binlerce kişi tarafindan stadyumlarda izlenen bu futbol gösterisini televizyon aracılığı ile milyonların evlerine taşımaktadır. Bu örnekten de anlaşılacağı üzere medya çok önemli bir unsurdur.

Futbol popüler yapan etkenler araştırmasında Ünal Şentürk' ün görüşlerine de değinecek olursak, futbolun bu kadar taraftar toplamasının sebepleri öncelikle; aklın, bedenin, hayal gücünün ve duyguların etkilerini içeren futbol, insanın kendi varlığında barındırdığı tüm yetenek, potansiyel güç ve eğilimlerin dışa vurumu olarak tanımlanabilir. İzleyenlere hoş vakit geçirme firsatı sunarak belli bir süre eğlenme olanağı sağlayan futbolun popüler olmasının arkasında bu gerçek yatmaktadır. Günümüzde insanın biliminden ve aklından ziyade; bilinçaltına, duygu, haz ve iç dünyasına hitap eden sinema, televizyon, bilgisayar, internet, müzik, eğlence ve spor endüstrisinin kitlelerin hayatlarını, zevklerini, beğenilerini ve anlam dünyalarını biçimlendiren bir mekanizma yapılandırdığı gözlemlenmektedir. Futbolun bu denli dikkat çekici ve popüler olması, insanların zevk, beğeni ve özel ilgilerin odak noktasında bulunması sebebiyle günden güne artış göstermiştir. Futbolun, mahallede çocukların oynadığı basit sahalardan, en teknik ve modern dev sahalara, televizyonlara, metropol sokaklarına kadar kitleselleşmesi ve küreselleşmesi, onun insanlar üzerindeki büyüsünün etkisiyle açıklanabilir. Sıkıcı iş ve tekdüze yaşam alışkanlığına karşı koyuşunu ifade ederek muhalif özelliği de taşıyan futbol, mevcut sistemin mekanikleştirici, yabancılaştırıcı ve ruhsuzlaştırıcı etkisini azaltma işlevi görmektedir. ${ }^{164}$

Futbolu popüler yapan etkenlerin gerek sosyolojik gerekse teknik donanım açısından irdelenmesi sonucu ortaya çıkan bu veriler, bize sanayi devriminden günümüze kadar sürekli

\footnotetext{
${ }^{163}$ Metin Argan ve Hakan Katırcı, Spor Pazarlaması. Ankara: Nobel Yayın ve Dağıtım' den akt: Selçuk Özdağ, Savaş Duman ve Bülent Fişekçioğlu, Popüler Kültür: Futbol mu Putbol mu?, Türkiye Kickboks Federasyonu Spor Bilimleri Dergisi, 2011, S:15

164 Ünal Şentürk, Popüler Bir Kültür Örneği Olarak Futbol, S:36
} 
etkileşim içerisinde olan toplulukların değişimlerini, yaşayış şekillerini, sosyal aktivitelerini göstererek, ortak bir paylaşım alanı sunulduğu görülmektedir. Tabi ki bu paylaşım alanının oluşumunu sağlayan en önemli unsurlardan birisi futbol olduğu görülmektedir.

\subsubsection{En Önemli Medya Unsuru Olarak Televizyon ve Futbol}

Televizyonun gücünün (medyanın) futbol üzerinde ne kadar etkili olduğunu yazar Andreas Klose "Futbol ve Kültürü" adlı eseri içerisinde vurgulamıştır. Televizyon, medyanın vazgeçilemez bir yapı taşı olduğundan dolayı futbolun popülerleşmesi medya ve televizyon unsurunun gelişmesiyle paralellik göstermektedir. Futbol oyununun medyatik(yeniden) üretimiyle, kendine özgü bir televizyon gerçekliği meydana gelmektedir ve yeni bir ürün yaratılmaktadır. Bunun adına da televizyon futbolu denmektedir. ${ }^{165}$

Televizyon futbolu, seyircinin dikkatini her türlü teferruattan arındırılmış futbol maçına odaklaştırmakta ve yönlendirmektedir. Hedefi ise, televizyonun ayrılmaz ilkeleri olan eğlence, gerilim ve dramatikliğin mükemmel uyarlamasıdır. Böylelikle medyatik işlem futbol sporunun algılanışını değiştirmektedir. "Kitlesel medyayla aktarılan bu algılama biçimi bir kez toplumsallaştığında, futbol oyununun 'yerinde', statta algılanması kaçınılmaz olarak eksikli hale gelmektedir." Önceden de bahsedildiği üzere, futbolun popülerleşme sürecinin aslında medyanın etkisiyle daha da aşama kaydettiğini söylersek kesinlikle yanılmış olmayı. ${ }^{166}$

Profesyonelleşme ve kitlesel medyatik pazarlama çerçevesinde ticarileşme süreçlerine bağlı olarak, futbol "proleter sporu" olmaktan çıkıp toplumsal kabul gören boş vakit eğlencesi haline gelmiştir. Toplumsal köklerinden kopmuştur fakat geniş toplumsal tabakalar içindeki çekiciliğini yitirmemiştir. Bilindiği üzere futbolun faaliyet alanı etkinliğini sürdürmekte ve günden güne arttırmaktadır. ${ }^{167}$

\footnotetext{
165 Roman Horak, Wolfgang Reiter, Tanıl Bora, Futbol ve Kültürü (Takımlar, Taraftarlar, Endüstri, Efsaneler) İçinde, Andreas Klose, Televizyon Futbolu (Medya Yapımı Bir Ürün Gerçekliği Nasıl Değiştirir), S: 374

166 Roman Horak, Wolfgang Reiter, Tanıl Bora, Futbol ve Kültürü (Takımlar, Taraftarlar, Endüstri, Efsaneler) İçinde, Andreas Klose, Televizyon Futbolu (Medya Yapımı Bir Ürün Gerçekliği Nasıl Değiştirir), S: 374

${ }^{167}$ Roman Horak, Wolfgang Reiter, Tanıl Bora, Futbol ve Kültürü (Takımlar, Taraftarlar, Endüstri, Efsaneler) İçinde, Andreas Klose, Televizyon Futbolu (Medya Yapımı Bir Ürün Gerçekliği Nasıl Değiştirir), S: 376
} 


\subsection{FUTBOLUN ENDÜSTRILEŞMESI}

Halkın oyunu olarak ortaya çıkan futbol, zaman içinde kabuk değiştirmeye başlamış ve günümüze kadar ulaşmıştır. ${ }^{168}$ Futbolun profesyonelleşme süreci, sportif etkinliklerin bir oyun olma özelliğinden çıkartıp, ekonomik düzeyde işleyen bir alana doğru evrilmiştir. Futbolda hızla endüstrileşen yeni futbol anlayışına doğru geçildikçe, futbolun sadece özü değil, insanların hayatı içerisindeki yeri de değişmeye başlamıştır. Bir oyun olmanın ötesinde futbol, toplumsal yaşam içinde bir 'minyatür' model olarak işlev görmekte ve onun üzerinden toplumsal yaşama bir takım rol ve değerler yüklemiştir. İşte bu noktada futbol, evrim geçirmiştir diyebilmek mümkündür. ${ }^{169}$

19.yüzyılın ortalarında başlayan modern futbolun macerası; daha önce çokça ifade edildiği üzere, modernleşme ve sanayileşme süreçleriyle üretim ve planlama modelleri arasında bir paralellik içermektedir. Futbolun endüstrileşme süreci hızlandıkça, futbol ekonomisi büyümekte bu bağlamda, futboldan alınan haz ve heyecanın boyutları değişmektedir. ${ }^{170}$

Futbol, yaygın düşüncenin tersine, toplumun büyük sorunlarının dışında kalan kurtarılmış bir bölge değildir. Aksine, büyük ekonomik çıkarlar, ideolojik çarpışmalar, ulusal ve uluslararası politikalarla şekillenen alanlardan biridir. Futbol çağımızın sorunlarının aynasıdır. ${ }^{171}$ Futbol içinde bulunduğumuz dönemin en önemli iktidar nesnelerinden bir tanesine dönüşmüştür ve bu yüzden futboldan söz edildiği zaman, aynı zamanda ekonomidensiyasetten-kimlikten-şiddetten-toplumsal yaşamdaki bazı değişimlerden ve sıkıntılardan söz etmemiz gerekmektedir. ${ }^{172}$

Değişim ve dönüşüm olgusu çerçevesinde futbolun özellikle kapitalist sürecin çemberi içine girmesi, bu oyunu artık küresel bir hale getirmiştir. Ahmet Talimciler'e göre futbol, artık bir meta haline dönüşmüştür ve bu haliyle, yaşantımızı yönlendiren tüketim kalıplarını

\footnotetext{
168 Ahmet Talimciler, Futbol değil iş: endüstriyel futbol, İletişim Kuram ve Araştırma Dergisi (Gazi Üniversitesi İletişim Fakültesi), Sayı 26 Kış-Bahar, 2008, Ankara, S: 92

${ }^{169}$ Ahmet Talimciler, Futbol değil iş: endüstriyel futbol, İletişim Kuram ve Araştırma Dergisi (Gazi Üniversitesi İletişim Fakültesi), S: 90

170 Talimciler, a.g.e., S: 91

171 Wahl, a.g.e., S: 79

172 Talimciler, a.g.e., S: 91
} 
şekillendirmek suretiyle oyun özelliğini yitirmeye başlamıştır. ${ }^{173}$ Ayrıca Talimciler, "kültür endüstrisi" kavramı ile birlikte metalaşma sürecinin yaratmış olduğu etkilerin, futbol ve futbol üzerinden toplumsal yaşam içerisinde nasıl bir ortamın doğmasına neden olduğunu da günümüzde görmekte olduğundan bahsetmiştir. ${ }^{174}$ Serbest zaman diye adlandırılan iş sonrası ve tatil dönemlerinin de metalaşma sürecine dahil olma açısından da önem arz ettiğini de vurgulamak gerekmektedir. Bu noktada futbol çok önemli bir serbest zaman etkinliği olarak da yeniden üretilme sürecine çoktan girmiştir.

Frankfurt okulunun 'kültür endüstrisi' kavramı ile vurgu yaptığı bu süreçte, hayatın her alanı metalaştırma ve hakim ideoloji kitlelerin bilincinde yeniden üretilmektedir. ${ }^{175}$

Hargreaveas' a göre de futbol, geleneksel katılımc1 eğlence ve kutlamaların karakteristiğini en yoğun biçimde yaşayan popüler kültür pratiklerinden biridir. ${ }^{176}$

Popüler kültür içinde çok önemli bir noktada yer alan futbolun yaratmış olduğu kültürel meta, milyonlarca insanın talepleri doğrultusunda bu noktalara varmıştır. Bu durum ancak günümüzde var olan taraftar olgusunun fazlaca etkin olmasıyla mümkündür. Tanıl Bora' ya göre ise , Popüler kültür endüstrisinin futbol kolu, hedef kitle olarak bu potansiyelle değil halihazır taraftar profiline odaklanmış durumdadır. Taraftar olmayan, veya "sıkı taraftar" olmayan, "sinema tiyatroya" gelir gibi maça gelmeyi düşünebilecek futbolseverler değil coşkulu ve oyunun neticesini değiştirebilecek ateşli bir futbol seyircisinden bahsetmektedir. ${ }^{177}$

Futboldaki bu taraftarlık olgusu göründüğg̈ üzere, gündelik hayattan ve sorumluluklardan uzaklaşmak bir nevi stres ve sıkıntılardan arınmak adına da bir kaçış alanı yaratmıştır. Şöyle ki, bir zamanlar çocuklarının futbolcu olmasına karşı çıkan aileler bile popülerleşmenin etkisiyle neredeyse çocuklarını zorla futbolcu yapma noktasına gelmişlerdir. $^{178}$

\footnotetext{
173 Talimciler, a.g.e., S: 92

174 Talimciler, a.g.e., S: 95

175 Talimciler, a.g.e., S: 99

176 J. Hargreaves, Sport, Culture and Ideology, S: 30-61 'den Akt: Talimciler, a.g.e., S:100

177 Tanıl Bora, Karhanede Romantizm, S: 48

178 Can Kozanoğlu, Bu Maçı Alıcaz, İletişim Yayınları, İstanbul, 1996, S: 61-62
} 


\subsubsection{Seyircinin Sahaya İnişi}

Futbolun endüstrileşme sürecinin etkisiyle, seyircinin sadece izleyici olarak kalmadığ yeniden üretim sistemi içerisinde aktif bir rol üstlendiğini de belirtmek gerekir. Seyirci, sadece stadyumlarda futbol maçı izlememekte aynı zamanda aktif olarak saha içinde oynayan konumunda olabilmektedir. Bu noktada "halı saha" adı verilen yeni bir futbol endüstrisi kolu ortaya çıkmıştır.

Halı saha futbolu, hem sosyal faaliyet tarzı hem de bir sektör olarak, 1980'lerin ikinci yarısında doğup büyüdü. Anayolların kenarında, mahalle aralarında, eski yazlık sinemaların kısmen otopark haline getirilmiş arsalarında mantar gibi biten halı sahalar, ortaya çıktıkları andan başlayarak hiç müşteri sıkıntısı çekmemişlerdir. Halı sahada "top oynamak", şehirli erkek nüfusunun önemli bir yüzdesinin gündelik hayatının olağan unsurları arasına girmiştir. ${ }^{179}$

17-50 yaş arası yetişkin erkeklerin azımsanmayacak bir yüzdesine etkinlik imkanı veren bu kurumun yerleşiklik kazanmış bulunuşudur. Halı sahaların, genç ve yaş ortalaması yüksek kesimlerin bir arada mücadele ettiği toplumsal ve sosyal bir etkinlik alanı olduğunu her şeyden evvel belirtmemiz gerekiyor. Halı sahaların ortaya çıkışıyla birlikte, bırakın futbol gibi özel efor isteyen bir oyunu, sporun her türlüsünden bütünüyle kopmuş insanların kendilerini spor mağazalarının vitrinlerine bakarken bulurlar. Halı saha, otuzunu aşmış insanların sahalara dönmesini sağladı. İşe giderken, işten dönerken, hafta sonu aileleriyle ya da akşamları arkadaşlarıyla gezmeye çıktıklarında olsa olsa kısa mesafeleri yürümek dışında hareket etmeyen bedenler, birden, belli başlı bütün kaslardan, bütün eklemlerden esneklik, k1vraklık talep eden bir sporun sillelerine kendilerini terk ettiler. ${ }^{180}$

Burada belirleyici olan yaş değildir; spordan kopmuş olmaktır. Hafta boyu çalışmadan sonra hafta sonu yağmur çamur dinlemeden maçtan maça koşmanın insanın kendini aşırı ölçülerde zorlamasını gerektirmesi, henüz futbol için elverişli yaşlarda -otuzun altındabulunan çalışan erkekleri de haliyle sporsuz bir hayata mahkum ediyordu. Halı saha özellikle bu grup için cazip oldu. Bu gruptakiler, genellikle işyerlerinde veya mahalle-arkadaş

\footnotetext{
179 Roman Horak, Wolfgang Reiter, Tanıl Bora, Futbol ve Kültürü (Takımlar, Taraftarlar, Endüstri, Efsaneler) İçinde, Ümit Kıvanç, Seyircinin Sahaya İnişi: Halı Saha Futbolu, S: 385

${ }^{180}$ Roman Horak, Wolfgang Reiter, Tanıl Bora, Futbol ve Kültürü (Takımlar, Taraftarlar, Endüstri, Efsaneler) İçinde, Ümit Kıvanç, Seyircinin Sahaya İnişi: Halı Saha Futbolu, S: 386
} 
çevrelerinde organize edilen halı saha maçlarının daha fazla koşan, yükü taşıyan kahramanlarıdır. Çünkü halı sahada genellikle yirmilerinin sonuna dayanmış "genç"lerle yolun yarısını -zaman zaman epeyce -aşmış orta yaşlılar bir arada oynamaktadır. Halı sahanın her an hizmete hazır bulunuşu, insanların seyirci-taraftar kimliğiyle zaten içinde yaşadıkları aleme bambaşka, etkin bir tarzda katılımını teşvik eden, sınırsız bir imkan olarak kendini sunmuştur. ${ }^{181} \mathrm{Bu}$ bağlamda da seyircinin bizzat oynamak istemesi, futbol seyirciliğinin doğasında vardır. Halı saha, imkansız görüneni mümkün kıldı, seyirciyi bizzat sahaya inme imkanı sundu. ${ }^{182}$

Özel olarak kendi toplumumuza değindiğimiz zaman; erkeklerin de kadınların da, bir aradayken asla ulaşamadıkları hazlara kendi aralarındayken ulaşabildiklerinin çok sayıda kanıtı vardır. Geçimini sağlamak gereken aile, kirası ödenecek ev, duruma göre, peşine düşülmüş, hayali kurulan ya da alınabilmiş otomobil v.b. ile yerleşik orta sınıf aile yaşantısının artık hayatın değişmez gerçeği haline geldiğini fark eden ve bu yüzden ilk tepkisi kendine ev dışında "hava değiştirecek" ortamlar aramak olan orta sınıf şehirli erkek için halı saha futbolu mükemmel bir "özel hayat" dilimi yaratmıştır. Erkek arkadaşlar vardır, erkekçe şakalar, güç mücadeleleri, soyunma odalarında özel esprilerle, artık dönülmesine imkan olmadığı düşünülen delikanlılık günlerinin havasının birden canlanıverdiği görülmektedir. ${ }^{183}$

Futbolun popüler kültürün en önemli unsurlarından biri olmasının sonucu olarak; seyircinin sahaya inmesiyle birlikte bambaşka bir sosyal alan halini alan futbol artık sadece izlenen ve hakkında konuşulan bir serbest zaman alışkanlığı değil, aynı zamanda aktif olarak oynanan bir oyun haline gelmiştir, diyebiliriz. Görüldüğü gibi futbol; oynayandan izleyene, kitle iletişim araçlarından, teknolojik gelişmelere kadar hayatın sürekli içinde var olmuş insanlıkla bir arada ilerleme göstermiş olan bir olgudur.

\footnotetext{
${ }^{181}$ Roman Horak, Wolfgang Reiter, Tanıl Bora, Futbol ve Kültürü (Takımlar, Taraftarlar, Endüstri, Efsaneler) İçinde, Ümit Kıvanç, Seyircinin Sahaya İnişi: Halı Saha Futbolu, S: 387

182 Roman Horak, Wolfgang Reiter, Tanıl Bora, Futbol ve Kültürü (Takımlar, Taraftarlar, Endüstri, Efsaneler) İçinde, Ümit Kıvanç, Seyircinin Sahaya İnişi: Halı Saha Futbolu, S: 388

183 Roman Horak, Wolfgang Reiter, Tanıl Bora, Futbol ve Kültürü (Takımlar, Taraftarlar, Endüstri, Efsaneler) İçinde, Ümit Kıvanç, Seyircinin Sahaya İnişi: Halı Saha Futbolu, S: 389
} 


\subsection{FUTBOL OYUNUNUN BİR ÖZGÜRLEŞME VE MÜCADELE ALANI OLARAK POTANSIYYLLIIKLERİ}

Futbol'un, son dönemde özellikle endüstrileşme süreciyle kabuk değiştirmesi, geçmişten günümüze kadarki süreç içerisinde kitlesini ve potansiyelliklerini arttırarak sürdürmesi sadece var olan sistemin çarkını döndüren bir alan olarak düşünülmemesi gerektiğini bize açık bir şekilde göstermektedir. Modern dönemde futbol, sadece bir oyun olmaktan çıkmıştır ve popüler kültürün özelliklerini en fazla yansıtan bir olgu haline dönüşmüştür, bu gerçek asla yadsınamaz ancak kendi içerisinde barındırdığ güç ile birlikte futbol; insanlara bir sığınma, bir mücadele ve kendilerini özgürce ifade edebildikleri bir ortam da yaratmıştır. Bu hususta futbolun, toplumsal yaşantı içerisindeki yeri ve gücü bizlere asla inkar edilemez bir gerçekliği tekrar hatırlatmaktadır, bu gerçeklik özellikle hayatın farklı farklı kesimlerinden olan kitleleri bir araya getirme, ortak bir dil oluşturma ve ortak bir kaygıya cevap verme şeklinde karşımıza çıkan bir gerçekliktir.

Futbol, günümüzün en önemli sorunlarından biri olarak algılanan sıkıcı iş ve tekdüze yaşam alışkanlıklarına karşı koyuşunu ifade eden bir muhalif özellik taşımaktadır. Var olan sistemin, mekanikleştirici, yabancılaştırıcı ve ruhsuzlaştırıcı etkisini azaltma ve kısa süreli dilimler halinde de olsa yok etme işlevi görmektedir. ${ }^{184}$ Tanıl Bora'ya göre ise futbol, popüler-kültürel yeniden-üretimi yine popüler dilin içinden, kendi içinde bir mücadeleye yeltenerek etki alanını arttırmış ve güçlendirmiştir. ${ }^{185}$ Futbol, her şeyden önce çok sevilen bir olgudur. Bu kelimenin olur olmaz kullanımları gibi değil, gerçekten de bir olgudur: Bir spor, bir oyun, bir ortam, bir iletişim ve sosyalleşme mecrasıdır. Kapsamlılı̆̆ı, birçok cephesi olması, ona olan sevginin hem boyutlarını büyütür hem biçimlerini çoğaltır ve bir mücadele bir özgürleşme alanı sunar. ${ }^{186}$

Futbol'un en etkileyici yanı, daha önce de ifade edildiği gibi, herkesin oynayabileceği çok kolay bir oyun olmasıdır. Nizami bir top yoksa, onun yerini alabilen bir plastik top da tutabilir, bezler, kağıtlar sıkıştırılıp iple bağlanarak yaratılmış bir topak da, bir teneke yahut gazoz kutusu da bir futbol topu işlevi görebilmektedir. Futbol; çim, toprak, halı saha yoksa, beton zeminde, koridorda da oynanabilen bir oyundur, okul bahçesinde ceketlerden direk

\footnotetext{
184 Şentürk, a.g.e, S:36

185 Tanıl Bora, Karhanede Romantizm, S:10

186 Bora, a.g.e, S:17
} 
yaparak, evin salonunda sandalyeleri kale niyetine kullanarak dahi oynanabilen ve gerek kapalı gerek açık alanlarda bir sosyalleşme ortamı yaratan, bireylerin özgürce hareket edebildikleri, kendilerini ifade edebildikleri ve gündelik hayatın sorunlarından kaçabildikleri bir sığınma mecrası halini almıştır. ${ }^{187}$

Futbolun ortaya çıkmasından itibaren yaratmış olduğu bu etki ile, yaşamakta olduğumuz dönemin yeniden üretimine tabi tutulmasına ve özellikle Huizinga'nın kuramı çerçevesinde oyunsal özelliklerini yitirmiş olmasına rağmen bir muhalif kimliğe sahip olduğunu da unutmamak gerekmektedir. Bu bağlamda modern futboldan bu yana varlığını sürdüren futbol kulüpleri, sadece birer futbol kulübü değil, kendi topluluklarını oluşturmuş adeta bir din ya da etnik köken gibi bütünleştiren ya da ayrıştıran köklü kurumlardır.

$\mathrm{Bu}$ bilgiler doğrultusunda şu ifadelere dikkat çekmek gerekmektedir: Futbol oyunu öteden beri, bir oyun olmaktan fazla bir şeydir. Futbol için genelde geçerli olan, tek tek takımlar için de geçerlidir. Avrupa'nın büyük kulüpleri, daima bir futbol kulübü olmaktan fazla bir şeydirler. Oluşum tarihi, takımın bileşimi ve oyun üslubu, bir bölgenin, bir kentin veya bir mahallenin, bir toplumsal, etnik veya dinsel grubun gerçek veya hayali kimliğinin metaforlarıdır: Örneğin İspanya'nın FC Barcelona kulübü "Katalan halkının epik yücelişidir"; İskoçya kulüpleri olan Glasgow Rangers militan Protestanlığın Celtic ise militan Katolikliğin bir forumudur. ${ }^{188}$

Görüldüğü üzere, futbolun sahip olduğu bu özgürleşme ve mücadele potansiyelliği asla sadece bir oyun ya da bir serbest zaman etkinliği olarak düşünülmemesi bunun ötesinde bir aidiyet olgusundan bahsedilmesi gerektiğini bizlere göstermektedir.

\footnotetext{
${ }^{187}$ Bora, a.g.e, S:23

${ }^{188}$ Roman Horak, Wolfgang Reiter, Tanıl Bora, Futbol ve Kültürü (Takımlar, Taraftarlar, Endüstri, Efsaneler) içinde Tanıl Bora, Takımlar-Taraftarlar-Efsaneler-Endüstri, S:22
} 


\section{SONUÇ}

Futbol oyununun tarihsel gelişim ve dönüşüm içerisindeki önemi ve yeri yadsınamaz. Futbol'un oyun olarak ortaya çıkışından itibaren günümüze kadar geldiği bu süreçte toplumları etkisi altına alması ve buna bağlı olarak yeniden üretilmesi popüler kültürün en önemli unsurlarından biri olmasının başlıca sebebidir çünkü futbol, kendi kulvarında rakibi olmayan ve milyonlarca insanı peşinden sürükleyin oyun ötesi bir olgu haline dönüşmüştür.

Çalışmamın birinci bölümünde bahsedilen kültür endüstrisi kavramı, kültürün değiş̧im süreci içerisinde nasıl yeniden üretildiğini bize işaret etmektedir. Kültür kavramının uğradığı bu değişimler gündelik hayatta farklı kavramların ortaya çıkmasına zemin hazırlamıştır. Bu kavramlardan en önemlisi de popüler kültür kavramıdır. Tam bu noktada popüler kültürün ortaya çıkışı da, bu endüstrileşmenin, bir başka tabirle yeniden üretilmenin bir sonucudur. Burada popüler kültürün, iktidar güçleri tarafından yönlendirilebiliyor olmasına rağmen aslında bir mücadele ve nefes alma alanı olarak da varllğını sürdürdüğü noktası ele alınmıştır. $\mathrm{Bu}$ hususta popüler kültürden bahsederken, ideolojik bir üst yapı kurumu niteliği taşıdığını vurgulamak gerekir. Popüler kültür, iktidarda olanların kültürüne karşı veya onun adına mücadele içerisinde olan alanlardan biri olarak kabul edilmektedir. Örneğin; burjuva kültürü, işçi sınıfının kültürünü değiş̧irerek ya da onu ortadan kaldırarak değil işçi sınıfının burjuva kültürü ile birlik olmasıyla bir sığınma ortamı yaratılmaktadır. Bu bilgiler ışığında popüler kültürü tanımlarken, gündelik hayatın kültürü olduğundan söz edilmiştir. İnsanların gereksinimleriyle örtüşen ve bunlarla birlikte var olan bir kültür öğesi olduğu vurgulanmaktadır. Tüm bu sığınma ve mücadele alanına rağmen popüler kültürün, toplumun ihtiyaçlarına göre varlığını arttırarak sürdürdüğü bu ihtiyaçların değişkenlik gösterdiği ve buna bağlı olarak yeniden üretimin en çarpıcı kesitlerinin sunulduğu kanısına varıldığını belirtmek gerekmektedir.

Çalışmamın ikinci bölümünde ele alınan "oyun" kavramı, Huizinga çerçevesinde değerlendirilmesi ve geçmişten günümüze kadar ulaşmış olan kültürel ve oyunsal öğelerin halen varlığını sürdürdüğü mü? Yoksa kendi özgünlüğünü kaybettiği ve yeniden üretim süreci içerisinde mi olduğu ? Gibi tartışmalarla birlikte eleştirel bir bakış açısıyla ifade edilmiştir. Şöyle ki; esas itibariyle oyun, gönüllü bir etkinliktir ve asla bir görev değildir. Oyun, kendi dünyasını yaratır ve bu noktada tüm çözümlemeleri ve mantıksal yorumlamaları reddeder. 
Oyun, özgürleşme alanıdır. Oyun, bu hayattan kaçarak kendine özgü eğilimleri olan ve kalıcı olmayan bir etkinlik alanına girme bahanesi sunmaktadır. Oyun bu özellikleri itibariyle olağan hayatın dışında yer aldığı hissedilen özgür ve kurmaca ancak yine de oyuncuyu tamamen içine çekme yeteneğine sahip bir eylemdir ancak başka bir ifade de yer alan tanımlamaya göre oyun, oyun olan ile oyun olmayanı ayrı bir yaşam alanı olarak düşünmek yerine, mevcut toplumsal ve kültürel düzey ile bir bütünlük içerisinde olan bir kavramdir.

$\mathrm{Bu}$ hususta, oyun bir amaca ya da bir çıkara hizmet ederse kendi özelliklerini yitirmesine rağmen var olan toplumsal süreç içerisinde gerçek dünyadan kopmadan, "kurmaca" içerisinde de gerçekliğini sürdürebilmesi sonucu ortaya çıkmaktadır.

Çalışmamın üçüncü bölümünde futbol oyununun tarihsel gelişim süreci ele alınmıştır. Önceki bölümde yer alan oyun kavramının bilinmesi ve tarihsel değişim süreci içerisinde farklı kavramlarla ifade edilmesi futbolun ortaya çıkması açısından bizlere çok önemli bir çıkış noktası sunmaktadır. Her şeyden evvel futbolun bir oyun olduğunun bilinmesi gerekmektedir. Diğer bütün oyunlar gibi futbol da belli bir amaca yönelik olarak ortaya çıkmıştır. Burada temel amaç, gönüllü bir faaliyet ve eğlenme ortama yaratılmaya çalışılmasıdır. Yapılan araştırmalara göre futbolun ilk örneklerine Çin'de rastlandığı görülmüştür. Özellikle ortaçağ döneminde futbol, adından çokça söz ettirmiştir, edebi eserlere konu olmuştur ve hatta kitlelerin çok etkilendiği bir mecra olmasından ötürü yasaklandığ̣ da görülmüştür. Bu gelişim süreci içerisinde futbolun asıl ortaya çıktığı yerin 19. yüzyılda İngiltere olduğu belirtilmiştir. Modern anlamda futbol İngiltere'de ortaya çıkmış ve günümüze kadar etkisini sürdürmüştür ve sürdürmeye etkili bir biçimde devam etmektedir. Modern futbolun 19. yüzyılda sanayi devrimi ile birlikte ortaya çıkması asla tesadüf değildir. Sanayi devriminin bir sonucu olarak var olan işçi sınıfının modern futbolun ortaya çıkışındaki yeri ve önemi çok büyüktür.

$\mathrm{Bu}$ noktada, kapitalist değişim süreci içerisinde yoğun çalışma saatleriyle hayatı sıkışmış olan işçi sınıfının futbolu bir özgürleşme alanı olarak görmesi futbolun gelişimi açısından çok önemli bir yere sahip olduğu kanısına varılmıştır. 
Çalışmamın son bölümünde, futbolun popülerliğini arttıran nedenlerden bahsedilmiştir. Futbol'un karakteristik özellikleri, kolay ve ucuz bir oyun olması, gerek kapalı gerekse de açık alanlarda oynanabilen bir oyun olması, gerçek futbol sahaları yerine herhangi bir alan içerisinde de keyif alınabilecek bir ortam yaratması gibi sebeplerden dolayı çok sevilen bir oyundur. Burada dikkat çekilen nokta, oynayandan başlayan süreç kitle iletişim araçlarının etkisiyle izleyene doğru bir evrim dönemine girmiştir. $\mathrm{Bu}$ evrilme noktasında özellikle televizyonun çok önemli bir aracı işlevi olduğu görülmektedir. Milyonlarca insan, futbol müsabakalarını televizyondan izlemekte ve hayatının en önemli serbest zaman etkinliklerinden birini yaratmaktadır.

Milyonları ekran başına kilitleyen, binlerce taraftarı ile stadyumları coşturan, yediden yetmiş yediye herkesin her zaman dilinde olan bu oyun, yeniden üretilme döneminin en önemli sonuçlarından biri olarak görülmektedir. Futbol, kapitalist düzen tarafından en fazla kuşatılan alanlardan biri halini almıştır. Halkın oyunu olarak ortaya çıkan futbol, profesyonelleşme süreci ve kitleleri peşinden sürüklemesinden dolayı bir oyun olma özelliğinden çıkmış, ekonomik düzeyde işleyen bir alan halini aldığı belirtilmiştir. Futbol sadece futbol değildir; siyasi, ideolojik ve ekonomik kaygıları olan bir olgu halini almıştır. Bir başka ifade ile futbol, içinde bulunduğumuz dönemin iktidar nesnelerinden biridir. $\mathrm{Bu}$ hususta, futbolun popüler kültürün en önemli örneklerinden biri olduğuna dikkat çekilmiştir.

Futbol' un oyunsal özelliklerini yitirmesine, endüstriyel bir iş kolu haline gelmesine rağmen toplumların yaşayışları açısından çok önemli bir konuma sahip olduğunun bilinmesi gerekmektedir. Toplumun her kesiminden insanlarının ortak bir paydada buluşabildiği nadir alanlardan biri de kuşkusuz futboldur. Toplulukları bir araya getirebilen, söz sahibi yapabilen, özgürleşme ve kendini ifade etme biçimi olabilen tek bir oyun vardır o da futboldur. Özel efor gerektiren bu aktivite genç ve yaş ortalaması yüksek kesimleri bir araya getiren toplumsal ve sosyal bir faaliyet imkanı da yaratmaktadır. Yoğun, sıkıcı ve tekdüze yaşam alışkanlıklarına karşı, bir muhalif olma özelliği taşıyan futbol, mevcut düzenin yabancılaştırıcı ve ötekileştirici etkisini azaltma işlevi görmektedir. Bu noktada futbol; bir sı̆̆ınma, özgürleşme, gündelik hayatın stres ve sıkıntılarından uzaklaşmak adına, adeta bir kaçış alanı sunmaktadır. 
Futbol kulüplerine karşı duyulan sevgi ve taraftarlık bağının, bireylerde bir aidiyet olgusu yarattığı görülmektedir. Taraftarların maddi bir çıkar elde etmeden, aksine kendi desteklediği kulübü için hiçbir maddi fedakarlıktan kaçınmamaları içinde bulunduğumuz dönemde tamamen manevi tatmin duygusunun bir nevi arınma ihtiyacının giderilmesinin boyutlarını gözler önüne sermektedir.

Tüm bu bilgiler doğrultusunda popüler kültürün unsuru olan futbol, oyunsal özelliklerini yitirip kapitalist sistemin en önemli çarklarından biri haline gelmiş olsa da, halen bir özgürleşme ve bir mücadele alanı potansiyelliği açısından çok önemli konuma sahip olduğu, bir sığınma mecrası ve sosyal faaliyet alanı özelliklerini koruyabileceği kanısına varılmıştır. 


\section{KAYNAKÇA}

a) Kitaplar

Adorno, Theodor W. Kültür Endüstrisini Yeniden Düşünürken, Bülent O. Doğan(çev.), Cogito, 2003.

Adorno, Theodor, Minima Morallia (Çev. Orhan Koçak, Ahmet Doğukan ), Metis Yayınları.

Akşar, Tuğrul, Endüsriyel Futbol, Literatür Yayınları, İstanbul, 2005.

Batmaz, Veysel, Medya Popüler Kültürü Gizler, Karakutu Yayınları, İstanbul, 2006.

Boniface, Pascal, Futbol ve Küreselleşme, Çev: İsmail Yerguz, Ntv Yayınları..5, İstanbul, 2007.

Bottomore, Tom, Frankfurt Okulu, Çev: Ahmet Çiğdem, Vadi Yayınları, 1994.

Bora, Tanıl, Karhanede Romantizm Futbol Yazıları, İletişim Yayınları, İstanbul, 2013.

Coşgun, Melek, Popüler Kültür ve Tüketim Toplumu, 2012.

Çalışlar, Aziz, Ansiklopedik Kültür Sözlüğü, Altın Kitaplar Yayın Evi, 1993

Ehrmann, Jacques "Homo Ludens Revisited" Jacques Ehrmann (Ed.), Game Play, Literature, Boston, 1968

Erdoğan, İrfan ve Alemdar, Korkmaz, Popüler Kültür ve İletişim, Ankara, 2005.

Fink, Eugen, "The Oasis of Happiness: Toward an Ontology of Play", Ehrmann po. ci

Fiske, John, Popüler Kültürü Anlamak, Ark Yayınları, Ankara, 1999.

Fişek, Kurthan, Sporun Anatomisi, YGS Yayınları, İstanbul, 2003.

Galeano, Eduardo, Gölgede ve Güneşte Futbol, Çev. Ertuğrul Önalp ve M. Necati Kutlu, Can Yayınları, İstanbul, 2011.

Hall, Stuart, Notes on the Deconstucting the Popular, Curan, j.et.al. Çev. Meral Özbek,1981 . 
Huizinga, Johan, Homo Ludens Oyunun Toplumsal İşlevi Üzerine Bir Deneme, (çev. Mehmet Ali Kılıçbay), Ayrıntı Yayınları, İstanbul, 2010.

Horak, Roman, Futbol Kültürü der.Roman Horak, Wolfgang Reiter, Tanıl Bora , İletişim Yayınlar1, 1993.

Koncavar, Ayşe, Modern Dönemde Kitle İletişim Araçlarında Mitoslar, Pales Yayınları, İstanbul, 2014

Köseoğlu, Nevzat, Milli Kültür ve Kimlik, İstanbul Yayınları, 1992.

Kurt, Metin ve Atayman, Veysel, Modern Sporun İlkelerinin Kökeni, "Arena Show" Modern Sporun Dünü ve Bugünü, Sorun Yayınları, İstanbul, 1997.'

Küçük, Mehmet, Medya İktidar İdeoloji, Bilim ve Sanat Yayınları, 2006.

Marcuse, Herbert Tek Boyutlu İnsan(ileri İşleyim Toplumunun İdeolojisi Üzerine İncelemeler, çev. Aziz Yardımlı, İdea Yayınları, 1986.

Oktay, Ahmet, Postmodernist Tahayyüle İtirazlar, İnkılap Yayıncılık, İstanbul, 2000.

Oskay, Ünsal, Yıkanmak İstemeyen Çocuklar Olalım, "Popüler Kültürün Toplumsal Ortamı ve İdeolojik İşlevleri Üzerine", Yapı Kredi Yayınları, İstanbul, 1998.

Oskay,Ünsal, XIX. Yüzyıldan Günümüze Kitle İletişiminin Kültürel İşlevleri, Der Yayınları, İstanbul.

Özbek, Meral, Popüler Kültür ve Orhan Gencebay Arabeski, İletişim yayınları, İstanbul, 2002.

Rowe, David, Popüler Kültürler (Rock ve Sporda Haz Politikası), Ayrıntı Yayınları, İstanbul. 
Sennett, Richard, Kamusal İnsanın Çöküşü, çev: Serpil Durak ve Abdullah Yılmaz, Ayrıntı Yayınları, İstanbul, 2013.

Sombart, Werner, Aşk, Lüks ve Kapitalizm, (Çeviren: Necati Ara), Bilim ve Sanat Yayınları, Ankara, 1998.

Stemmler, Theo, Futbolun Kısa Tarihi, Dost Yayınları, Ankara, 2000.

Talas, Cahit, Sosyal Politika, Sevinç Matbaası, Ankara, 1967.

Touraine, Alain , Modernliğin Eleştirisi, 4. Bask1, (Çeviren: Hülya Tufan), Yap1 Kredi Yayınları, İstanbul, 2002.

Wahl, Alfred, Ayaktopu Futbolun Öyküsü, Genel Kültür Dizisi, Yapı Kredi Yayınları, 1998.

Williams, Raymond, Anahtar Sözcükler(Kültür ve Toplumun Sözvarlı̆̆ı), İletişim Yayınları, 2012.

Williams, Raymond, İkibin'e Doğru, Ayrıntı Yayınları, İstanbul, 1989.

Williams, Raymond, Televizyon, Teknoloji ve Kültürel Biçim, Dost Yayınları, Ankara, 2003.

b) Makaleler ve Dergiler

Bourdiou Pierre ve Wacquant L.J.D, An Invitation to Reflexive Sociology, Chicago ve Londra University of Chicago Press.

Cogito, Dünya Gözüyle Futbol , Yapı Kredi Yayınları, Sayı:63, 2010.

Erdoğan, İrfan, "Futbolun İncelenmesi”, İletişim Kuram ve Araştırma Dergisi, Gazi Üniversitesi, Say1 26, 2008. 
Erdoğan, İrfan, "Popüler Kültürde Gasp ve Popülerin Gayri Meşruluğu”, Doğu Batı Dergisi, 4. Say1, 2001, Ankara.

Erimhan, Ahmet, Medya ve Değişim, Yeni Türkiye Dergisi Medya Özel Sayısı. 12, 1503$1507,1996$.

Orta, Lale, Futbol Oyun Kurallarının Evrimi (1863-2008), Gazi Üniversitesi İletişim Fakültesi Kuram ve Araştırma Dergisi içinde, sayı 26 kış-bahar, 2008.

Özdağ, Selçuk, Duman, Savaş ve Fişekçioğlu, Bülent, Popüler Kültür: Futbol mu Putbol mu?, Türkiye Kickboks Federasyonu Spor Bilimleri Dergisi, Sayı: 4, Sayı:1, Ocak, 2011

Özkan, Hasan, Hüseyin, Popüler Kültür ve Eğitim, Kastamonu Eğitim Dergisi.

Özkan,Özgür ,Dirim, Futbolun Kültürü Spor mu, Oyun Mu Yoksa (hala) Afyon mu?, KÜLT: İstanbul Bilgi Üniversitesi, Kültürel Çalışmalar, Sayı 2.

Saruhan, Şadi, Can ve Özdemirci, Ata Kurum, Ürün ve Marka İmajının Oluşmasında Popüler Kültürün Yeri ve Önemi: Çok Partili Dönemin Yükselen Sektörleri Üzerine Geçmişe Yönelik Bir İnceleme,1950-1980.

Şen, Mustafa, Kemal, ve Hira, İsmail, Frankfurt Okulu ve Kültür Endüstrisi Eleştirisi, Politika Dergisi, 2011.

Şahin, Mustafa, Yaşar ve Tunçkol, H.Mehmet, İşçi Hareketlerinin Futbolun Tarihsel Gelişim Sürecine Etkisi 220 TSA/YIL:14, S:1, NISAN 2010.

Şentürk, Ünal, Popüler Bir Kültür Örneği Olarak Futbol, C.Ü. Sosyal Bilimler Dergisi, 2007.

Talimciler, Ahmet, Futbol değil iş: endüstriyel futbol, İletişim Kuram ve Araştırma Dergisi (Gazi Üniversitesi İletişim Fakültesi), Sayı 26 Kış-Bahar, 2008, Ankara. 
Ünkaracalar, Dilşad, Asena, Dede-Nine Torun Kuşaklar Arası Çatışmalarda Popüler Kültür.

Y., Uğur Halk Sporu Kurultayı, İnsanca Spor Dergisi(1), 2012.

c) Tezler ve Yayınlanmamış Çalışmalar

Durgeç, Petek, Popüler Kültür Bağlamında Mizah Dergilerinin Değişen İşlev: Penguen Dergisi, Yayınlanmamış Yüksek Lisans Tezi.

Yöney, Gülşah, Pilpil, Kitlelerin Afyonu Futbolun Latin Amerika Edebiyatındaki Yankıları Yayınlanmamış Yüksek Lisans Tezi, Ankara Üniversitesi Sosyal Bilimler Enstitüsü Batı Diller Ve Edebiyatları (İspanyol Dili Ve Edebiyatı) Anabilim Dalı, 2012.

d) Ansiklopediler

Temel Britannica, Hürriyet Gazetesi Yayınları, Cilt 11, İstanbul, 1993.

e) İnternet Kaynakları

https://www.academia.edu/9881624/DEDE_N\%C4\%B0NE_TORUN_KU\%C5\%9EAKLAR_ ARASI_\%C3\%87ATI\%C5\%9EMALARDA_POP\%C3\%9CLER_K\%C3\%9CLT\%C3\%9CR (20.03.2015)

http://halkkulturu.nedir.com (20.03.2015)

http://www.irfanerdogan.com/makaleler1/popne.htm, Eğitim Dergisi (20.03.2015)

https://www.academia.edu/9881624/DEDE_N\%C4\%B0NE_TORUN_KU\%C5\%9EAKLAR_ ARASI_\%C3\%87ATI\%C5\%9EMALARDA_POP\%C3\%9CLER_K\%C3\%9CLT\%C3\%9CR - (20.03.2015)

http://mimesis-dergi.org/2011/05/oyunun-tanimi-ve-toplum-yasantisindaki-yeri/ (04.04.2015)

http://ds.anadolu.edu.tr/eKitap/SYT101U.pdf (10.04.2015)

http://www.thefa.com/about-football-association/history (23.04.2015)

http://www.futbolsahalari.com/futbol-oyun-kurallari.html (02.05.2015) 
